\title{
Compilation of Stratigraphic Thicknesses for Caldera-Related Tertiary Volcanic Rocks, East-Central Nevada and West-Central Utah
}

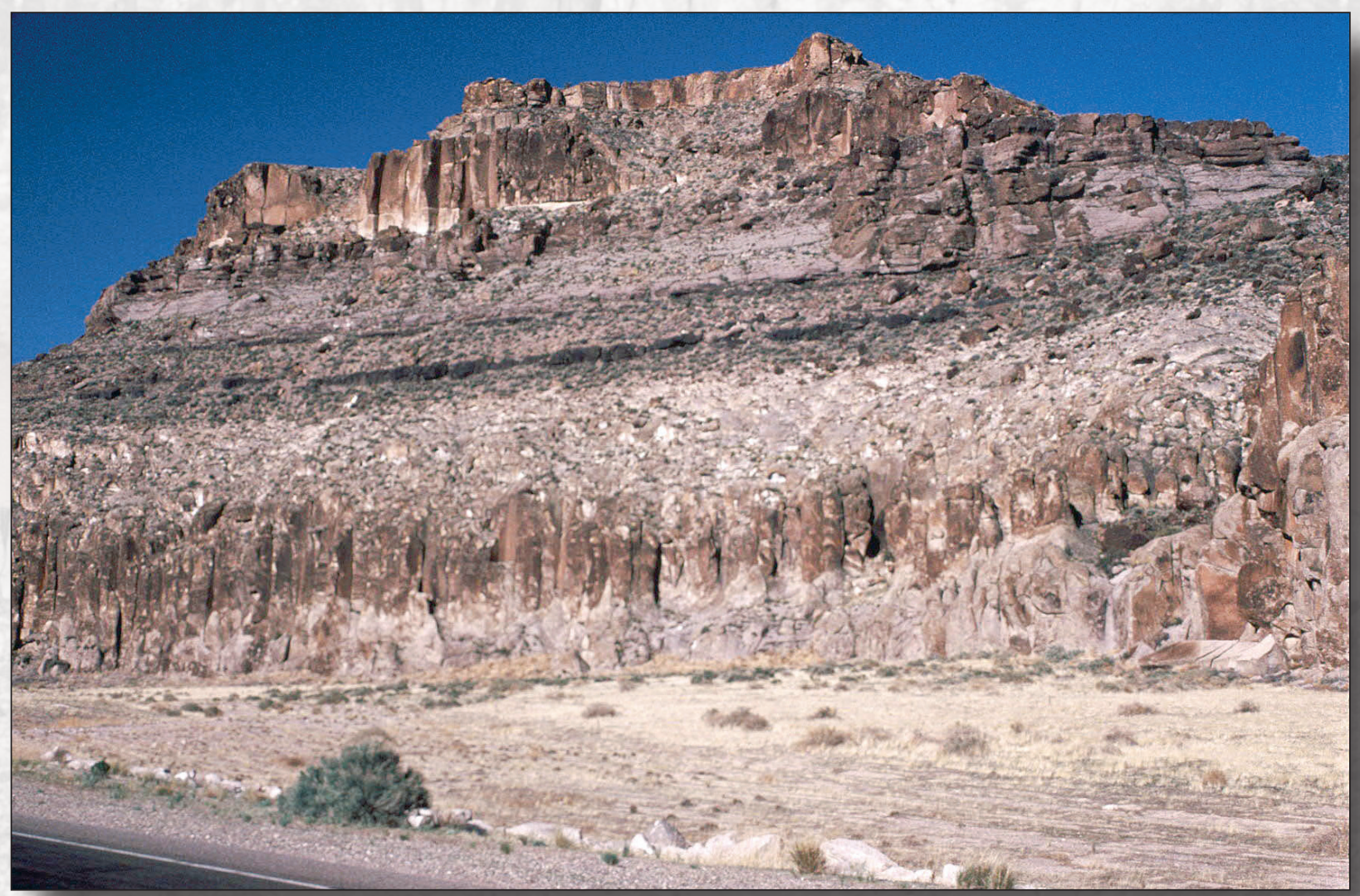

Data Series 271

U.S. Department of the Interior

U.S. Geological Survey 


\section{Compilation of Stratigraphic Thicknesses for Caldera-Related Tertiary Volcanic Rocks, East-Central Nevada and West-Central Utah}

By D.S. Sweetkind and E.A. du Bray

Prepared in cooperation with the Bureau of Land Management

Data Series 271 


\section{U.S. Department of the Interior DIRK KEMPTHORNE, Secretary}

\section{U.S. Geological Survey \\ Mark D. Myers, Director}

\section{U.S. Geological Survey, Reston, Virginia: 2008}

For product and ordering information:

World Wide Web: http://www.usgs.gov/pubprod

Telephone: 1-888-ASK-USGS

For more information on the USGS - the Federal source for science about the Earth,

its natural and living resources, natural hazards, and the environment:

World Wide Web: http://www.usgs.gov

Telephone: 1-888-ASK-USGS

Any use of trade, product, or firm names is for descriptive purposes only and does not imply endorsement by the U.S. Government.

Although this report is in the public domain, permission must be secured from the individual copyright owners to reproduce any copyrighted materials contained within this report.

Suggested citation:

Sweetkind, D.S., du Bray, E.A., 2008, Compilation of stratigraphic thicknesses for caldera-related tertiary volcanic rocks, east-central Nevada and west-central Utah: U.S. Geological Survey Data Series 271, 40 p. 


\section{Contents}

Abstract
Introduction
Geologic Setting
Compilation Methods
Stratigraphic Thicknesses from Geologic Maps
Published Isopach Data
Summary
References Cited.

\section{Figures}

1. Carbonate rock province, BARCAS study area, and associated regional

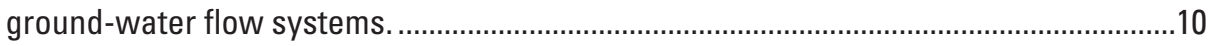

2. Generalized diagram of ash-flow caldera ....................................................................11

3. Generalized geology map and locations of calderas, eastern Nevada and

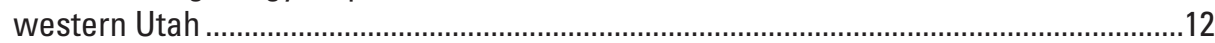

4. Index of geologic maps in the vicinity of the Indian Peak caldera complex used to compile volcanic rock thicknesses ...................................................................13

5. Thickness (isopach) map of Kalamazoo Tuff................................................................14

6. Thickness (isopach) map of Windous Butte Formation .................................................15

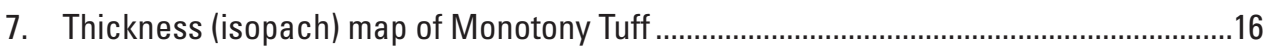

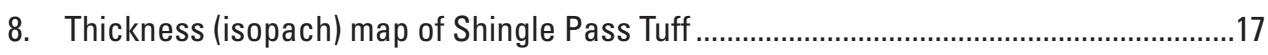

9. Thickness (isopach) map of Cottonwood Wash Tuff ........................................................18

10. Thickness (isopach) map of Wah Wah Springs Formation..............................................19

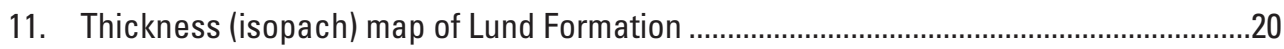

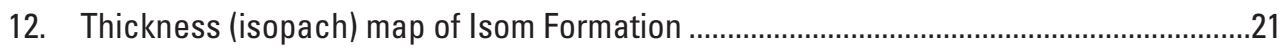

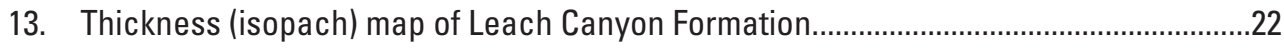

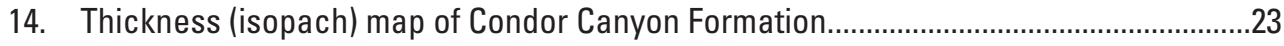

15. Thickness (isopach) map of Harmony Hills Tuff. ...........................................................24

16. Aggregate thickness (isopach) map of all tuffs for caldera-related Tertiary volcanic rocks in east-central Nevada and west-central Utah.......................................25

17. Volcanic thickness (isopach) map showing location of valley axes in eastern Nevada and western Utah described in tables 1-13 ...................................................26

18. Comparison of tuff thickness compilation methods, east-central Nevada and west-central Utah. Associated table is listed at top of bar

\section{Tables}

1. Compilation of volcanic-rock thickness from mountain ranges flanking the northern part of Dry Lake Valley. 
2. Compilation of volcanic-rock thickness from mountain ranges flanking Muleshoe Valley.

3. Compilation of volcanic-rock thickness from mountain ranges flanking Cave Valley.

4. Compilation of volcanic-rock thickness from mountain ranges flanking southern part of Lake Valley.

5. Compilation of volcanic-rock thickness from mountain ranges flanking northern part of Lake Valley.

6. Compilation of volcanic-rock thickness from mountain ranges flanking southern part of Spring Valley.

7. Compilation of volcanic-rock thickness from mountain ranges flanking the central part of Spring Valley.

8. Compilation of volcanic-rock thickness from mountain ranges flanking southern part of Hamlin Valley.

9. Compilation of volcanic-rock thickness from mountain ranges flanking northern part of Hamlin Valley.

10. Compilation of volcanic-rock thickness from mountain ranges flanking Snake Valley.

11. Compilation of volcanic-rock thickness from mountain ranges flanking southern part of Pine Valley.

12. Compilation of volcanic-rock thickness from mountain ranges flanking northern part of Pine Valley.

13. Compilation of volcanic-rock thickness from mountain ranges flanking Wah Wah Valley.

\section{Conversion Factors}

\begin{tabular}{lcl}
\hline Multiply & By & To obtain \\
\hline inch & 2.54 & centimeter $(\mathrm{cm})$ \\
inch & 25.4 & millimeter $(\mathrm{mm})$ \\
foot $(\mathrm{ft})$ & 0.3048 & meter $(\mathrm{m})$ \\
mile $(\mathrm{mi})$ & 1.609 & kilometer $(\mathrm{km})$ \\
centimeter $(\mathrm{cm})$ & 0.3937 & inch (in.) \\
millimeter $(\mathrm{mm})$ & 0.03937 & inch (in.) \\
meter $(\mathrm{m})$ & 3.281 & foot $(\mathrm{ft})$ \\
kilometer $(\mathrm{km})$ & 0.6214 & mile (mi) \\
\hline
\end{tabular}

Horizontal coordinate information is referenced to the North American Datum of 1983 (NAD 83). 


\title{
Compilation of Stratigraphic Thicknesses for Caldera-Related Tertiary Volcanic Rocks, East-Central Nevada and West-Central Utah
}

\author{
By D.S. Sweetkind and E.A. du Bray
}

\section{Abstract}

The U.S. Geological Survey (USGS), the Desert Research Institute (DRI), and a designee from the State of Utah are currently conducting a water-resources study of aquifers in White Pine County, Nevada, and adjacent areas in Nevada and Utah, in response to concerns about water availability and limited geohydrologic information relevant to ground-water flow in the region. Production of ground water in this region could impact water accumulations in three general types of aquifer materials: consolidated Paleozoic carbonate bedrock, and basin-filling Cenozoic volcanic rocks and unconsolidated Quaternary sediments. At present, the full impact of extracting ground water from any or all of these potential valley-graben reservoirs is not fully understood. A thorough understanding of intermontane basin stratigraphy, mostly concealed by the youngest unconsolidated deposits that blanket the surface in these valleys, is critical to an understanding of the regional hydrology in this area. This report presents a literature-based compilation of geologic data, especially thicknesses and lithologic characteristics, for Tertiary volcanic rocks that are presumably present in the subsurface of the intermontane valleys, which are prominent features of this area.

Two methods are used to estimate volcanic-rock thickness beneath valleys: (1) published geologic maps and accompanying descriptions of map units were used to compile the aggregate thicknesses of Tertiary stratigraphic units present in each mountain range within the study areas, and then interpolated to infer volcanic-rock thickness in the intervening valley, and (2) published isopach maps for individual outflow ash-flow tuff were converted to digital spatial data and thickness was added together to produce a regional thickness map that aggregates thickness of the individual units. The two methods yield generally similar results and are similar to volcanic-rock thickness observed in a limited number of oil and gas exploration drill holes in the region, although local geologic complexity and the inherent assumptions in both methods allow only general comparison. These methods serve the needs of regional ground-water studies that require a three-dimensional depiction of the extent and thickness of subsurface geologic units. The compilation of geologic data from published maps and reports provides a general understanding of the distribution and thickness of tuffs that are presumably present in the subsurface of the intermontane valleys and are critical to understanding the ground-water hydrology of this area.

\section{Introduction}

As populations in the southwestern United States continued to increase through the 1990s and 2000s, reliance on water from the Colorado River basin has become increasingly important. To decrease their dependence on this limited surface-water resource, water purveyors in southern Nevada have proposed to use the ground-water resources of rural basins in eastern and central Nevada to help provide for the projected increase in population and associated water supply issues in the Las Vegas area. Most of these basins historically (prior to 2006) have pumped limited quantities of ground water, typically less than 20,000 acre-ft per year. As a result, municipal and regulatory agencies have expressed concerns about potential impacts from increased ground-water pumping on local and regional water quantity and quality, with particular concern for water rights issues and on the future availability of water to support natural spring flow and native vegetation. Before concerns for potential impacts from pumping can be addressed, municipal and regulatory agencies have recognized the need for additional information and improved understanding of geologic features and hydrologic processes that control the rate and direction of ground-water flow in eastern and central Nevada.

In response to concerns about water availability and limited geohydrologic information, Federal legislation was enacted in December 2004 (Section 301(e) of PL 108-424, Lincoln County Conservation, Recreation, and Development Act of 2004; short title, Lincoln County Land Act) that directed the Secretary of the Interior, through the U.S. Geological Survey (USGS), the Desert Research Institute (DRI), and a designee from the State of Utah, to conduct a water-resources study of the alluvial and carbonate aquifers in White Pine County, Nev., and adjacent areas in Nevada and Utah. The main objectives 
of the study, termed the Basin and Range Carbonate Aquifer System study, or the BARCAS study, were to evaluate: (1) the extent, thickness, and hydrologic properties of aquifers in the study area, (2) the volume and quality of water stored in these aquifers, (3) subsurface geologic structures controlling groundwater flow, (4) ground-water flow direction and gradients, and (5) the distribution and rates of recharge and ground-water discharge. Geologic, hydrologic, and supplemental geochemical information were integrated to determine individual basin and regional ground-water budgets. A draft report containing the preliminary results of the BARCAS study was released for public comment in Spring, 2007 (Welch and Bright, 2007); final results will be summarized in a USGS Scientific Investigations Report (SIR) that will be prepared in cooperation with DRI and the State of Utah, and submitted to Congress by December 2007. The BARCAS study final report will be supported by a series of USGS reports, including this report, and the DRI Hydrologic Sciences Reports that document, in greater detail than the BARCAS study final report, important components of this study.

The BARCAS study area encompasses about $35,000 \mathrm{~km}^{2}$, including about 80 percent of White Pine County, and parts of Elko, Eureka, Nye, and Lincoln Counties in Nevada, as well as parts of Tooele, Millard, Beaver, Juab, and Iron Counties in Utah (fig. 1). The BARCAS study area lies within the Carbonate Rock Province, a relatively large area extending from western Utah to eastern California (fig. 1) where ground-water flow is predominantly or strongly influenced by carbonaterock aquifers (Winograd and Thordarson, 1975; Bedinger and others, 1989; Dettinger and others, 1995; Harrill and Prudic, 1998). Much of the carbonate-rock aquifer is fractured, and these fractured rocks, where continuous, form a regional flow system that receives recharge from higher altitude areas in White Pine County where these fractured carbonate rocks are exposed. Water moving through the carbonate aquifer provides some recharge to overlying basin-fill aquifers, sustains many of the larger, perennial lower elevation springs in the study area, and hydraulically connects similar carbonate-rock aquifers in adjacent basins. Most areas in White Pine County, Nev., are within four regional ground-water flow systems (fig. 1) - the larger Colorado and Great Salt Lake Desert flow systems, and the smaller Goshute Valley and Newark Valley flow systems.

Production of ground water from the BARCAS study area could impact water accumulations in three general types of aquifer materials: consolidated Paleozoic carbonate bedrock, and basin-filling Cenozoic volcanic rocks and unconsolidated Quaternary sediments. At present, the full impact of extracting ground-water from any or all of these potential, valley-graben reservoirs is not fully understood. A thorough understanding of intermontane basin stratigraphy, mostly concealed by the youngest unconsolidated deposits that blanket the surface in these valleys, is critical to an understanding of the regional hydrology in this area.

The middle Tertiary geologic evolution of east-central Nevada is dominated by volcanic events that produced many ash-flow tuffs deposited during caldera-forming eruptions
(Best, Christiansen, and others, 1989). Fractured Cenozoic volcanic rocks near the major volcanic fields are locally thick enough to be important subregional aquifers that interact with the regional flow through the underlying Paleozoic carbonate rocks (Dettinger, 1989; Harrill and others, 1988). Eruption dynamics cause ash-flow sheets to be distributed as much as hundreds of kilometers from their sources, to pond in topographic lows, and to mantle topography. Outflow thicknesses of individual ash-flow sheets that form a variety of tuffs can be hundreds of meters and the aggregate thickness of the outflow deposits that erupted from multiple calderas in east-central Nevada can be kilometers thick. Within the BARCAS study area, eruption of many of the ash-flow tuffs occurred relatively early in the extensional history of the area (Axen and others, 1993). As a consequence, regionally distributed ash-flow tuffs are preserved deep in the stratigraphy of the downfaulted basins, often covered by thick intervals of younger sedimentary deposits.

Because eruptive events that caused caldera formation are such major parts of the geologic framework in east-central Nevada, a general understanding of caldera dynamics and the distribution and thickness of outflow tuffs is critical to understanding the ground-water hydrology of this area. This report presents a literature-based compilation of geologic data, especially thicknesses and lithologic characteristics, for Tertiary rocks (mostly volcanic) that are presumably present in the subsurface of the intermontane valleys, which are prominent features of this area. In addition, the calderas themselves, as well as their associated structural features, are addressed because these features are significant relative to the area's ground-water hydrologic framework. These data are intended to support analysis for the extent, thickness, and hydrologic properties of volcanic-rock aquifers for the BARCAS study.

\section{Geologic Setting}

Processes related to large-volume ash-flow eruptions and associated caldera collapses are enumerated by Smith and Bailey (1968) and by Lipman (1984) and are summarized below. Calderas can be as much as $120 \mathrm{~km}$ in diameter, are structurally complex features, and most are bounded by a pair of geologic discontinuities, a structural margin and a topographic margin (fig. 2), both of which may be obscured by subsequent volcanism and erosion. These discontinuities are generally concentric and related to the structural collapse that is the hallmark of caldera-forming eruptions. Calderas form when large volumes of magma are nearly instantaneously erupted from shallowly emplaced magma reservoirs. As an eruption of this type ensues, the associated magma reservoir is partially evacuated by the eruption of frothy magma, and the central block of roof rock that lay above the reservoir collapses downward along a series of arcuate faults. The resulting system of faults forms a generally circular system of normal faults that constitute the caldera's structural margin. The lithologic discontinuity across the 
steeply inclined structural margin can be profound and can extend to depths of several kilometers. The resulting caldera wall begins to retreat outward as landslides calve off the oversteepened walls and contribute material to the deepening depression caused by the eruption and concomitant central collapse of the volcanic edifice (fig. 2). Outward retreat of the caldera boundary by subsequent landsliding forms a second, more gently inclined concentric discontinuity known as the topographic margin. Simultaneous with central collapse and landslide formation, the evolving central depression begins to be filled by the volcanic products derived from the ongoing eruption. This rapidly evolving intracaldera environment is usually filled by a kilometers-thick accumulation of ash-flow tuff and interleaved landslide materials (fig. 2). The discontinuity across the caldera's topographic margin, between intracaldera tuff and the country rock that host the caldera, can be at least as profound as that across the structural margin. Following caldera-forming eruptions, some of these igneous systems experience a central upward resurgence of unerupted magma from the underlying magma reservoir. Resurgence further complicates and disrupts the geology within the caldera (fig. 2).

The Cenozoic geologic evolution of east-central Nevada is dominated by a broad southward sweep of essentially calcalkaline igneous activity (McKee, 1971; Cross and Pilger, 1978; McKee and Noble, 1986; Best, Christiansen, and others, 1989) with volcanic rocks, especially ash-flow tuffs, deposited during caldera-forming eruptions (Best, Christiansen, and others, 1989). Between about 30 and $25 \mathrm{Ma}$, calderarelated eruptions from two major centers, the Indian Peak caldera complex (IPCC, fig. 3) and the Central Nevada caldera complex (CNCC, fig. 3), formed a broad zone of voluminous upper Oligocene-lower Miocene volcanic rocks (Best, Christiansen, and others, 1989) that extended across Nevada and Utah. Subsequently, ash-flow eruptions from numerous nested calderas of the 23 to $13 \mathrm{Ma}$ Caliente caldera complex resulted in regionally extensive ash-flow tuffs that are centered in the east-central part of Lincoln County (Scott and others, 1995) (fig. 3).

The Indian Peak caldera complex (IPCC, fig. 3), centered on the eastern side of Lake Valley in the northern part of Lincoln County, erupted on the order of $10,000 \mathrm{~km}^{3}$ of volcanic rock between about 32 and $27 \mathrm{Ma}$ (Best, Christiansen, and Blank, 1989). At least four major calderas have been identified within this complex (fig. 3) based on the presence of thick intracaldera tuff sequences and collapse breccias; two other calderas are inferred from the presence of regionally extensive ash-flow sheets (Best and Grant, 1987; Best, Christiansen, and Blank, 1989). Best, Christiansen, and Blank (1989) estimated that ash-flow tuffs erupted from the Indian Peak caldera complex alone cover about 55,000 km² in east-central Nevada. The spatial distribution of circular, caldera-related ring fracture systems and faults related to the Indian Peak caldera complex in east-central Nevada and westcentral Utah were compiled by Loucks and others (1989) and Williams and others (1997).
The Central Nevada caldera complex (CNCC, fig. 3), in the northern part of Nye County, was even larger than the Indian Peak caldera complex. The Central Nevada caldera complex may include as many as 12 calderas and there are multiple sheets of rhyolite tuff with larger volumes than those in the Indian Peak caldera complex (Best, Christiansen, and others, 1989; Best and others, 1993). Eruptions from this complex were protracted, beginning at about $35.3 \mathrm{Ma}$ and extending to 22.6 Ma (Best and others, 1993).

The Caliente caldera complex (CCC, fig. 3), about $80 \mathrm{~km}$ to the south of the Indian Peak caldera complex, erupted several thousand cubic kilometers of volcanic material between about 23 and $19 \mathrm{Ma}$ (Williams, 1967). The dimensions of the Caliente caldera complex are about $80 \mathrm{~km}$ east-west and $35 \mathrm{~km}$ north-south, unusually elongated for a major caldera complex. The Caliente caldera complex consists of numerous nested calderas of 23-13 Ma, including the Clover Creek caldera, north and east of Caliente, which was the source of the densely welded Bauers Tuff Member of the Condor Canyon Formation, and the Delamar caldera, which makes up most of the western part of the complex and was the main source for the 18.3 Ma Hiko Tuff (Rowley and others, 2001).

A smaller volume, but locally important, ash-flow tuff called the Kalamazoo Tuff by Gans and others (1989) is widely distributed across northern White Pine County, Nev., and adjacent areas of Utah. This tuff, and associated overlying volcanic rocks, is inferred to have a source area in the northern part of Spring Valley (KT, fig. 3); eruptive volume may be 240-340 km (Gans and others, 1989), an order of magnitude smaller than the largest ash-flow tuffs from the caldera complexes described above.

A final consideration concerning the middle Tertiary volcanic stratigraphy of east-central Nevada pertains to the lavas (and associated pyroclastic and volcaniclastic deposits) that are a significant, though not especially voluminous, part of the geologic framework of this area. Best, Christiansen, and others (1989) suggested that lavas constitute only about 10 percent of the total volume of Cenozoic volcanic rock in this region. However, because this is not an inconsequential amount of rock, lava flow thicknesses were considered as a possible contribution to Tertiary sections in the intermontane valleys of east-central Nevada. Most of these lavas are andesitic to rhyolitic and are often associated with calderas in the area, although there are locally important accumulations that are not associated with calderas, such as the volcanic rocks at the south end of Butte Valley, $30 \mathrm{~km}$ northwest of Ely, Nev. (Feeley and Grunder, 1991). Lava flow eruption dynamics typically result in discontinuous deposits that are not as broadly distributed around eruption sources, or as far traveled as ash-flow tuffs. The presence and thicknesses of individual lava flow sequences in the stratigraphic sections of the intermontane valleys is more difficult to determine than that for ash-flow tuffs, and can potentially lead to significantly greater uncertainty relative to intermontane valley Tertiary volcanic rock thickness estimates. In addition, lava flow rocks may have very different porosity, fracture styles, and fracture intensity than adjacent 
rocks in this area, and so may be spatially associated with significant ground-water hydrology discontinuities. Consequently, the thicknesses, lithologic character, and hydrologic properties of middle Tertiary lava flow rocks, as well as all other rock types that constitute parts of the hydrologic framework in east-central Nevada, must be well defined in order to accurately define the hydrologic framework for the region.

As a result of pyroclastic eruptions, caldera formation processes, and wide distribution of the associated ash-flow tuffs, calderas and their erupted products can profoundly influence, in a myriad of ways, ground-water hydrology in terranes that host these features. First, in trying to determine the types and thicknesses of geologic materials that may be preserved in the intermontane valleys of east-central Nevada, one must consider the likelihood that significant accumulations of middle Tertiary ash-flow tuff are preserved in many of these valleys. The lithologic characteristics of these rocks must be considered with regard to their ability to serve as water reservoirs, the extent of their hydraulic conductivity, and their interconnectedness to reservoirs either above in basin-fill sedimentary deposits or below in the Paleozoic rock aquifers. Next, the role of the topographic and structural margins with regard to ground-water hydrology must be considered. Depending on the geologic characteristics of these features, they may serve as either conduits or impermeable interfaces to ground-water flow. Similarly, the nature of the lithologic contrast between rocks exposed on either side of these discontinuities must be considered. The nature of the lithologic juxtaposition can have profound affects on ground-water storage and flow frameworks. In addition, the intersections between modern intermontane valleys and older intracaldera features must be considered. Places where intermontane valleys intersect intracaldera rocks and structures are places where profound geologic discontinuities may be present. In particular, structural and lithologic discontinuities present in these places can impact inferred reservoir geometry as well as ground-water flow. The distribution of calderas and associated eruptive products in east-central Nevada must be well understood in order to comprehend how they may contribute to the overall ground-water hydrology of this area.

\section{Compilation Methods}

\section{Stratigraphic Thicknesses from Geologic Maps}

Published geologic maps (fig. 4) and descriptions of map units were used to compile the aggregate thicknesses of Tertiary stratigraphic units present in each mountain range within the study areas (tables 1-13). These units are probably preserved in down-faulted, Cenozoic graben valleys of eastcentral Nevada and west-central Utah, and probably are about as thick in the valleys as they are in the flanking mountain ranges. Descriptions of map units contained on the published geologic maps almost always include thickness data, although usually somewhat generalized, for each unit whose distribution is shown on the geologic map. The Tertiary deposits are primarily volcanic rocks but include some interbedded sedimentary deposits. Mapped volcanic rocks are mostly regionally distributed ash-flow tuffs but also include significant volumes of lava flows. Geologic map units were subdivided into local and regional units (tables 1-13). Local units were those units with limited spatial extent within a single mapped quadrangle or mountain range; typically lava flows and Tertiary sedimentary rocks interbedded with tuff. Regional units were those units that occur in several quadrangles or mountain ranges. These volcanic-rock units are typically ash-flow tuffs associated with a caldera-forming eruption. Minimum and maximum thickness data were compiled for each map unit (tables 1-13), although many map unit descriptions indicate only maximum thicknesses. Unless minimum thicknesses were explicitly identified in source materials, minimum thicknesses are presumed to be zero. In order to estimate the stratigraphic thicknesses of Tertiary strata concealed beneath Quaternary deposits in each Cenozoic graben valley, we assume that their thicknesses are similar to those in the flanking mountain ranges.

The physiography of east-central Nevada is dominated by an alternating series of approximately north-trending valleys and mountain ranges. For the purposes of aggregating published thickness values, many of these valleys were divided into segments along their lengths, to allow consideration of geologic variability along valley lengths. The resulting data compilation (tables 1-13) preserves a level of detail commensurate with the detail and geologic variability portrayed on maps that depict the geology of ranges adjacent to each valley.

Stratigraphic thickness data were compiled as a series of valley segment components (tables $1-13$ ). In most cases, each valley segment component of the tables presents two sets of thickness data. The first set presents thicknesses for Tertiary strata preserved in the range west of the valley segment, and the second for strata in the range east of the valley. In some cases, as noted on the tables, volcanic rocks and associated geologic data may be available for the range on one side of a valley but not on the other (for instance, the northern part of Lake Valley, table 5). In these cases, some proxy, as defined on the affected tables, is established for the missing information so as to enable valley thickness estimates.

Lava flows usually result in limited, near source distributions, whereas tuffs are distributed in a broad, regional fashion. Consequently, lava flows present in mountain ranges may not have flowed into regions that are now intermontane valleys. In contrast, ash-flow tuffs are known to have been deposited with much greater continuity over thousands of square kilometers. Recognizing these potential distribution variations, thickness data for Tertiary lava flow units were compiled separately from those for the ash-flow tuff units. An additional consideration relative to valley thickness estimates relates to whether ash-flow tuffs of east-central Nevada and west-central Utah were deposited as intracaldera tuff or as outflow tuff sheets. Intracaldera ash-flow tuff accumulations are known to be extremely thick (Lipman, 1984; Lipman and 
Sawyer, 1985) and pertain to the intracaldera setting only. Consequently, only outflow ash-flow tuff thicknesses, those most likely to be representative of volcanic rocks that are presumably present in the subsurface of the intermontane valleys, were compiled. However, some valley segments, such as southern parts of Hamlin Valley (table 8) and Lake Valley (table 4), that are coincident with the intracaldera environment may preserve huge intracaldera ash-flow tuff thicknesses beneath Quaternary deposits.

Using the geologic relationships described above and interpolating stratigraphic thicknesses of Tertiary ash-flow tuffs between adjacent ranges, the thickness of tuffs potentially preserved in the intervening valleys may be estimated. The resulting tuff thickness estimates are not biased to the potentially erroneously high thickness estimates that would result from assuming that near-source lava flows are continuously preserved from adjacent ranges across intervening graben valleys. Interpolated thicknesses in valleys, based solely on regionally distributed ash-flow tuff thicknesses, are considered reasonable estimates of minimum concealed thicknesses of Tertiary rocks in the valleys. Accordingly, a highlighted entry in the center of each table presents the probable thickness range for Tertiary rocks in the associated valley segment. Because minimum thicknesses of the constituent stratigraphic units are very poorly known in most cases, the low end of these thickness ranges is unlikely to be diagnostic. The high end of each thickness range represents a value intermediate to the total thicknesses of regionally distributed Tertiary strata in the flanking mountain ranges.

In addition to thickness data, the data compilation (tables 1-13) contains additional geologic information. For each intermontane valley segment, stratigraphic units identified in one or both of the ranges that flank the valley are identified. One list identifies the stratigraphic units (mostly lava flows) that are deemed to be of local extent, and the other identifies those units (mostly major ash-flow tuffs) that are likely to be regionally distributed. Because the lithologic characteristics of each map unit potentially influence the hydrologic properties of these deposits, a brief description, including degree of welding, texture, and crystal content of stratigraphic units described in each pair of flanking ranges, is included (tables 1-13).

\section{Published Isopach Data}

A second method for estimating the stratigraphic thicknesses of Tertiary ash-flow tuffs that might be preserved in the intermontane valleys of east-central Nevada and western Utah is from published thickness (isopach) maps for individual ash-flow tuffs. The voluminous, regionally distributed Tertiary ash-flow tuffs have been extensively studied (see, for example, Best and Grant, 1987; Best, Christiansen, and others, 1989; du Bray, 1995; Scott and others, 1995) and the database derived from these studies is quite comprehensive. Consequently, synthesis of thickness data for many individual ash-flow tuffs is possible. Thickness data have been extremely important in identifying the sources of individual ash-flow tuffs and also in locating calderas that formed in response to major eruptive events. In general, the areas of greatest ash-flow tuff thickness are spatially coincident with calderas. However, mapped ash-flow tuffs in east-central Nevada and western Utah greatly outnumber identified calderas. In some cases, a caldera may be inferred from the volume of an ash-flow tuff unit, yet its location may be unknown because it has been subsequently disrupted by younger structural or erosional events, or buried by younger rocks.

Isopach maps have been compiled for most of the major, regionally distributed ash-flow tuffs of east-central Nevada and west-central Utah. One of the earliest efforts to compile isopach maps for this region was that of Williams (1967), who synthesized thickness data for ash-flow tuffs related to the Caliente caldera complex, including the Harmony Hills Tuff, the Condor Canyon Formation which comprises the Bauers Tuff and Swett Tuff Members, and the Leach Canyon Formation. Williams also compiled a maximum extent of distribution map for the Pahranagat Formation from the central Nevada caldera complex. Subsequent mapping of these rocks has resulted in refinements to the stratigraphic nomenclature (Rowley and others, 1995; Scott and others, 1995), but the initial thickness compilations remain valid. Isopach maps for some large-volume ash-flow tuffs from the central Nevada caldera complex, including the Windous Butte Formation, the Monotony Tuff, and the Shingle Pass Tuff were produced by Best, Christiansen, and others (1989). Best, Christiansen, and Blank (1989) also compiled thickness data for ash-flow tuffs of the Indian Peak caldera complex; this compilation includes isopach diagrams for the Cottonwood Wash Tuff, Wah Wah Springs Formation, Lund Formation, and Isom Formation. The distribution and thickness of the Kalamazoo Tuff and associated overlying volcanic rocks across northern White Pine County, Nev., and adjacent areas of Utah was portrayed by Gans and others (1989). Thickness maps are thus available for the majority of the voluminous, regionally distributed ash-flow tuffs present in east-central Nevada and west-central Utah.

The published isopach maps were scanned and georeferenced in a Geographic Information System (GIS) and the location and thickness values as measured at outcrops of individual tuffs were digitized from these published maps. In order to preserve the original author's interpreted contour patterns, additional thickness data were created by digitizing a regular series of points along each contour line of the isopach maps. For each tuff, these thickness data were gridded as 2,500-m square cells within the GIS to produce a digital thickness grid as raster data sets. Thickness was gridded using either inverse distance or simple kriging algorithms; the gridding methodology was chosen on the basis of how closely the digital grid resembled the original published contour map. Grids were locally hand-edited in order to recreate abrupt thickness changes at known or inferred caldera boundaries. Using this approach, digital thickness grids were created for the following ash-flow tuffs: the Kalamazoo Tuff (fig. 5), the Windous Butte Formation (fig. 6), the Monotony Tuff (fig. 7), the Shingle Pass Tuff (fig. 8), the Cottonwood 
Wash Tuff (fig. 9), the Wah Wah Springs Formation (fig. 10), the Lund Formation (fig. 11), the Isom Formation (fig. 12), the Leach Canyon Formation (fig. 13), the Condor Canyon Formation (fig. 14), and the Harmony Hills Tuff (fig. 15). In each of these figures two maps are shown. The larger map portrays the thickness of the individual ash-flow tuff contoured using intervals that display most clearly the thickness variations of the unit. The smaller map in each figure shows the same thickness data, but contoured at intervals consistent with those used for the thickest tuffs in the region. Thus the reader may see the details of the thickness variations within each tuff and also gain an understanding of the thickness of the ash-flow tuff as compared to the largest eruptions in the study area. In many cases, the thickest intervals do not exactly correspond to mapped caldera boundaries. This disparity is usually the result of limited outcrop data; in most cases the thickness and distribution of the intracaldera fill on published isopach maps may be represented by a single data point. In a few cases, the caldera boundaries themselves are only generally located, or the thickness of the intracaldera volcanic rocks is poorly known due to disruption by younger structural events, or burial by younger rocks. Thickness data portrayed on the individual isopach maps were added together to produce a composite isopach map that combines the gridded thickness for all of the previously named units (fig. 16). The composite isopach map is dominated by the thick intracaldera accumulations within the Indian Peak caldera complex and the central Nevada caldera complex (fig. 3). The thickness of intracaldera rocks within the Caliente caldera complex (fig. 3) may be underrepresented in this compilation due to the relative lack of published thicknesses of intracaldera rocks; however, these eruptions were generally much smaller in volume than the other two main caldera centers. Using the composite isopach map (fig. 16), one can predict the relative thickness of outflow tuffs between the caldera complexes.

\section{Comparison of Thickness Compilation Methods}

The two thickness compilation methods may be compared at specific valley-axis locations by overlaying the gridded total thickness map and the predicted valley-axis thickness compiled from data contained in published descriptions of map units (fig. 17). A comparison of the two methods at these locations (fig. 18) suggests that the two methods yield generally similar results. Thickness predicted by the gridded data is necessarily generalized because it relies on interpolation between relatively scarce measured sections. Gridded thickness maps were created only for those tuffs for which published isopach maps were available. Certain regionally distributed tuffs, such as those emanating from the Marysvale volcanic field in south-central Utah (Rowley and others, 1979; Rowley and others, 1998) were not considered in this analysis and volcanic-rock thickness may be underestimated, especially in the valleys of western Utah. The thickness derived from descriptions of map units is principally affected by the fact that thicknesses presented in geologic descriptions of map units are somewhat generalized and imprecise in most cases. Stratigraphic thicknesses are typically reported as ranging from zero to a maximum value (tables 1-13), neither of which may be representative of the thickness commonly observed in outcrop.

Available subsurface data from oil and gas exploration wells drilled in valleys of east-central Nevada (Hess and others, 2004) and west-central Utah (Hintze and Davis, 2003) are shown on figures 17 and 18 . These data are generally similar to the predicted values but also emphasize the degree of local variability and the limitations of such general compilations. For example, in Lake Valley one well intersected $826 \mathrm{~m}$ of volcanic rocks (fig. 17) whereas a second well about $15 \mathrm{~km}$ to the south did not encounter any volcanic rocks (fig. 17), even though this well is located within a buried caldera that is inferred to underlie Lake Valley. Farther to the east in northern Hamlin Valley and southern Snake Valley, one well penetrated over $320 \mathrm{~m}$ of volcanic rocks and did not penetrate the base of the volcanic sequence (fig. 17); another well only $4 \mathrm{~km}$ to the northeast encountered about $140 \mathrm{~m}$ of volcanic rocks before penetrating Paleozoic carbonate rocks below. In both of these situations, the bedrock exposures on either side of the valleys contain faulted Paleozoic rock outcrops blanketed by the Cenozoic volcanic section; projection of this outcrop geology into the subsurface would produce a variety of predicted thicknesses of volcanic rocks, depending on the degree of volcanic rock preservation and paleogeographic complexity of the surface on which they were deposited. These examples emphasize that methods of thickness compilation presented here may be of use in defining regional variations in predicted thickness, but are not appropriate for site-specific subsurface geology.

\section{Summary}

The middle Tertiary geologic history of east-central Nevada is dominated by volcanic events, especially emplacement of regionally distributed ash-flow tuffs deposited during caldera-forming eruptions. Regional ground-water studies such as the BARCAS study require a three-dimensional depiction of the extent and thickness of subsurface geologic units that provides a conceptual and numerical framework of the subsurface distribution of the aquifer materials. Typically, this requires the ability to predict the thickness of a rock unit that is of interest across a very large area on the basis of a small number of data points. Compilation of geologic data from published maps and reports provides a general understanding of the distribution and thickness of tuffs that are presumably present in the subsurface of the intermontane valleys and are critical to understanding the ground-water hydrology of this area. The data compiled in this report have been used as direct input in the construction of a simplified three-dimensional geologic model of the BARCAS study area (Watt and Ponce, 2007) and have also been used in 
water budget calculations for the BARCAS study area (Welch and Bright, 2007). Predicted thicknesses that are based on geologic descriptions of map units may overestimate or underestimate regional thickness trends because such descriptions often report a minimum and maximum thickness. It is possible that average thicknesses would provide a more likely estimate of tuff thickness at any particular location within the area addressed by this publication. Predicted thicknesses derived by combining isopach maps for individual tuffs are dependent on the availability of such maps and the underlying field data used to create the maps. Neither method is accurate for predicting local site-scale variability in volcanic-rock thickness, which can only be derived from a combination of drilling and geophysical methods.

\section{References Cited}

Abbott, J.T., Best, M.G., and Morris, H.T., 1983, Geologic map of the Pine Grove-Blawn Mountain area, Beaver County, Utah: U.S. Geological Survey Miscellaneous Investigations Series Map I-1479, scale 1:24,000.

Axen, G.J., Taylor, W.J., and Bartley, J.M., 1993, Space-time patterns of the onset of extension and magmatism, southern Great Basin, Nevada, Utah, and California: Geological Society of America Bulletin, v. 105, p. 56-76.

Bedinger, M.S., Langer, W.H., and Reed, J.E., 1989, Groundwater hydrology, in Bedinger, M.S., Sargent, K.A., and Langer, W.H., eds., Studies of geology and hydrology in the Basin and Range Province, southwestern United States, for isolation of high-level radioactive waste-Characterization of the Death Valley region, Nevada and California: U.S. Geological Survey Professional Paper 1370-F, 49 p.

Best, M.G., Christiansen, E.H., and Blank, R.H., Jr., 1989, Oligocene caldera complex and calc-alkaline lavas of the Indian Peak volcanic field: Geological Society of America Bulletin, v. 101, p. 1076-1090.

Best, M.G., Christiansen, E.H., Deino, A.L., Gromme, C.S., McKee, E.H., and Noble, D.C., 1989, Excursion 3A-Eocene through Miocene volcanism in the Great Basin of the Western United States, in Chapin, C.E., and Zidek, J., eds., Field excursions to volcanic terranes in the Western United States, v. II, Cascades and Intermountain West: New Mexico Bureau of Mines and Mineral Resources Memoir 47, p. 91-133.

Best, M.G., and Grant, S.K., 1987, Stratigraphy of the volcanic Oligocene Needles Range Group in southwestern Utah and eastern Nevada: U.S. Geological Survey Professional Paper 1443-A, 28 p.

Best, M.G., Grant, S.K., Hintze, L.F., Cleary, J.G., Hutsinpiller, A., and Saunders, D.M., 1987, Geologic map of the Indian Peak (southern Needle) Range, Beaver and Iron Counties, Utah: U.S. Geological Survey Miscellaneous Investigations Series Map I-1795, scale 1:50,000.
Best, M.G., and Hintze, L.F., 1980, Preliminary geologic map of the Halfway Summit quadrangle, Millard and Beaver Counties, Utah: U.S. Geological Survey Miscellaneous Field Studies Map MF-1153, scale 1:24,000.

Best, M.G., Hintze, L.F., Deino, A.L., and Maughan, L.L., 1998, Geologic map of the Fairview Range and Grassy Mountain, Lincoln County, Nevada: Nevada Bureau of Mines and Geology Map 114, scale 1:24,000.

Best, M.G., Hintze, L.F., and Homes, R.D., 1987, Geologic map of the southern Mountain Home and northern Indian Peak Ranges (central Needle Range), Beaver County, Utah: U.S. Geological Survey Miscellaneous Investigations Series Map I-1796, scale 1:50,000.

Best, M.G., Lemmon, D.M., and Morris, H.T., 1989, Geologic map of the Milford quadrangle and east half of the Frisco quadrangle, Beaver County, Utah: U.S. Geological Survey Miscellaneous Investigations Series Map I-1904, scale $1: 50,000$.

Best, M.G., Morris, H.T., Kopf, R.W., and Keith, J.D., 1987, Geologic map of the southern Pine Valley area, Beaver and Iron Counties, Utah: U.S. Geological Survey Miscellaneous Investigations Series Map I-1794, scale 1:50,000.

Best, M.G., Scott, R.B., Rowley, P.D., Swadley, W C, Anderson, R.E., Gromme, C.S., Harding, A.E., Deino, A.L., Christiansen, E.H., Tingey, D.G., and Sullivan, K.R., 1993, Oligocene-Miocene caldera complexes, ash-flow sheets, and tectonism in the central and southeastern Great Basin, in Lahren, M.M., Trexler, J.H., Jr., and Spinosa, Claude, eds., Crustal evolution of the Great Basin and the Sierra Nevada: Cordilleran/Rocky Mountain Section, Geological Society of America Guidebook, University of Nevada, Reno, Nev., p. 285-311.

Best, M.G., Toth, J.B., Kowallis, J.B., Willis, J.B., and Best, V.C., 1989, Geologic map of the northern White Rock Mountains-Hamlin Valley area, Beaver County, Utah, and Lincoln County, Nevada: U.S. Geological Survey Miscellaneous Investigations Series Map I-1881, scale 1:50,000.

Cross, T.A., and Pilger, R.H., 1978, Constraints on absolute motion and plate interaction inferred from Cenozoic igneous activity in the western United States: American Journal of Science, v. 278, p. 865-902.

Dettinger, M.D., 1989, Reconnaissance estimates of natural recharge to desert basins in Nevada, U.S.A., by using chloride-balance calculations: Journal of Hydrology, v. 106, p. 55-78.

Dettinger, M.D., Harrill, J.R., Schmidt, D.L., and Hess, J.W., 1995, Distribution of carbonate-rock aquifers and the potential for their development, southern Nevada and parts of Arizona, California, and Utah: U.S. Geological Survey Water-Resources Investigations Report 91-4146, 100 p. 
Drewes, Harald, 1967, Geology of the Connors Pass quadrangle, Schell Creek Range, east-central Nevada: U.S. Geological Survey Professional Paper 557, scale 1:48,000.

du Bray, E.A., 1995, Geochemistry and petrology of Oligocene and Miocene ash-flow tuffs of the southeastern Great Basin, Nevada: U.S. Geological Survey Professional Paper $1559,38 \mathrm{p}$.

Ekren, E.B., and Page, W.R., 1995, Preliminary geologic map of the Coyote Spring quadrangle, Lincoln County, Nevada: U.S. Geological Survey Open-File Report 95-550, scale $1: 24,000$.

Feeley, T.C., and Grunder, A.L., 1991, Mantle contribution to the evolution of Middle Tertiary silicic magmatism during early stages of crustal extension; The Egan Range volcanic complex, east-central Nevada: Contributions to Mineralogy and Petrology, v. 106, p. 154-169.

Gans, P.B., Mahood, G.A., and Schermer, Elizabeth, 1989, Synextensional magmatism in the Basin and Range province; A case study from the eastern Great Basin: Geological Society of America Special Paper 233, 53 p.

Harrill, J.R., Gates, J.S., and Thomas, J.M., 1988, Major ground-water flow systems in the Great Basin region of Nevada, Utah, and adjacent states: U.S. Geological Survey Hydrologic Investigations Atlas HA-694-C, scale $1: 1,000,000,2$ sheets.

Harrill, J.R., and Prudic, D.E., 1998, Aquifer systems in the Great Basin region of Nevada, Utah, and adjacent States-A summary report: U.S. Geological Survey Professional Paper 1409-A, 66 p.

Hess, R.H., Fitch, S.P., and Warren, S.N., 2004, Nevada Oil and Gas Well Database (NVOILWEL): Nevada Bureau of Mines and Geology Open-File Report 04-1, 242 p.

Hintze, L.F., and Best, M.G., 1987, Geologic map of the Mountain Home Pass and Miller Wash quadrangles, Millard and Beaver Counties, Utah, and Lincoln County, Nevada: U.S. Geological Survey Miscellaneous Field Studies Map MF-1950, scale 1:24,000.

Hintze, L.F., 1974a, Preliminary geologic map of the Conger Mountain quadrangle, Millard County, Utah: U.S. Geological Survey Miscellaneous Field Studies Map MF-634, scale 1:48,000.

Hintze, L.F., 1974b, Preliminary geologic map of the Wah Wah Summit quadrangle, Millard and Beaver Counties, Utah: U.S. Geological Survey Miscellaneous Field Studies Map MF-637, scale 1:48,000.

Hintze, L.F., 1981, Preliminary geologic map of the Tunnel Spring quadrangle, Millard County, Utah: U.S. Geological Survey Miscellaneous Field Studies Map MF-1334, scale $1: 24,000$.
Hintze, L.F., 1986, Geologic map of the Mormon Gap and Tweedy Wash quadrangles, Millard County, Utah, and Lincoln and White Pine Counties, Nevada: U.S. Geological Survey Miscellaneous Field Studies Map MF-1872, scale 1:24,000.

Hintze, L.F., and Davis, F.D., 2003, Geology of Millard County, Utah: Utah Geological Survey Bulletin 133, 305 p.

Hintze, L.F., Willis, G.C., Laes, D.Y.M., Sprinkel, D.A., and Brown, K.D., 2000, Digital geologic map of Utah: Utah Geological Survey Map 179DM, 1 CD-ROM, scale 1:500,000.

Hose, R.K., 1965, Geologic map and sections of the Conger Range SE quadrangle and adjacent area, Confusion Range, Millard County, Utah: U.S. Geological Survey Miscellaneous Geologic Investigations Map I-435, scale 1:24,000.

Hose, R.K., Blake, M.C., Jr., and Smith, R.M., 1976, Geology and mineral resources of White Pine County, Nevada: Nevada Bureau of Mines and Geology Bulletin 85, 105 p.

Keith, J.D., Tingey, D.G., and Best, M.G., 1994, Geologic map of the Rice Mountain Quadrangle, Nevada and Utah: Nevada Bureau of Mines and Geology Field Studies Map 7, scale $1: 24,000$.

Kellogg, H.E., 1964, Cenozoic stratigraphy and structure of the southern Egan Range, Nevada: Geological Society of America Bulletin, v. 75, p. 949-968.

Lipman, P.W., 1984, The roots of ash flow calderas in western North America-Windows into the tops of granitic batholiths: Journal of Geophysical Research, v. 89, p. 8801-8841.

Lipman, P.W., and Sawyer, D.A., 1985, Mesozoic ash-flow caldera fragments in southeastern Arizona and their relation to porphyry copper deposits: Geology, v. 13, p. 652-656.

Loucks, M.D., Tingey, D.G., Best, M.G., Christiansen, E.H., and Hintze, L.F., 1989, Geologic map of the Fortification Range, Lincoln and White Pine Counties, Nevada: U.S. Geological Survey Miscellaneous Investigations Series Map I-1866, scale 1:50,000.

McKee, E.H., 1971, Tertiary igneous chronology of the Great Basin of western United States-Implications for tectonic models: Geological Society of America Bulletin, v. 82, p. 3497-3502.

McKee, E.H., and Noble, D.C., 1986, Tectonic and magmatic development of the Great Basin of western United States during late Cenozoic time: Modern Geology, v. 10, p. 39-49.

Page, W.R. and Ekren, E.B., 1995, Preliminary geologic map of the Bristol Well quadrangle, Lincoln County, Nevada: U.S. Geological Survey Open-File Report 95-580, scale 1:24,000. 
Raines, G.L., Sawatzky, D.L., and Connors, K.A., 1996, Great Basin geoscience data base: U.S. Geological Survey Digital Data Series DDS-41, 2 CD-ROMs.

Rowley, P.D., Cunningham, C.G., Steven, T.A., Mehnert, H.H., and Naeser, C.W., 1998, Cenozoic igneous and tectonic setting of the Marysvale volcanic field and its relation to other igneous centers in Utah and Nevada, in Friedman, J.D., and Huffman, A.C., Jr., eds., Laccolith complexes of southeastern UtahTime of emplacement and tectonic setting-Workshop proceedings: U.S. Geological Survey Bulletin 2158, p. 167-202.

Rowley, P.D., Nealey, L.D., Unruh, D.M., Snee, L.W., Mehnert, H.H., Anderson, R.E., and Gromme, C.S., 1995, Stratigraphy of Miocene ash-flow tuffs in and near the Caliente caldera complex, southeastern Nevada and southwestern Utah, in Scott, R.B., and Swadley, W C, eds., Geologic studies in the Basin and Range-Colorado Plateau transition, southeastern Nevada, southwestern Utah, and northwestern Arizona: U.S. Geological Survey Bulletin 2056-B, p. 43-88.

Rowley, P.D., Snee, L.W., Anderson, R.E., Nealey, L.D., Unruh, D.M., and Ferris, D.E., 2001, Field trip to the Caliente caldera complex, east-striking transverse zones, and nearby mining districts in Nevada-Utah-Implications for petroleum, ground-water, and mineral resources, in Erskine, M.C., Faulds, J.E., Bartley, J.M., and Rowley, P.D., eds., The geologic transition, High Plateaus to Great Basin-A symposium and field guide (The Mackin Volume), Utah Geological Association and Pacific Section of the American Association of Petroleum Geologists: Utah Geological Association Publication No. 30, p. 401-418.

Rowley, P.D., Steven, T.A., Anderson, J.J., and Cunningham, C.G., 1979, Cenozoic stratigraphic and structural framework of southwestern Utah: U.S. Geological Survey Professional Paper 1149, 22 p.

Scott, R.B., Gromme, C.S., Best, M.G., Rosenbaum, J.G., and Hudson, M.R., 1995, Chapter A, Stratigraphic relationships of Tertiary volcanic rocks in central Lincoln County, southeastern Nevada, in Scott, R.B., and Swadley, W C, eds., Geologic studies in the Basin and Range Colorado Plateau transition in southeastern Nevada, southwestern Utah, and northwestern Arizona, 1992: U.S. Geological Survey Bulletin 2056, p. 7-41.

Smith, R.L., and Bailey, R.A., 1968, Resurgent calderas: Geological Society of America Memoir 116, p. 613-662.

Stewart, J.H., Carlson, J.E., Raines, G.L., Connors, K.A., Moyer, L.A., and Miller, R.J., 2003, Spatial digital database for the geologic map of Nevada: U.S. Geological Survey Open-File Report 2003-66. Available on-line at: http://pubs. usgs.gov/of/2003/of03-66/.

Swadley, W C, Page, W.R., and Scott, R.B., 1994, Preliminary geologic map of the Deadman Spring NE quadrangle, Lincoln County, Nevada: U.S. Geological Survey Open-File Report 94-283, scale 1:24,000.
Toth, M.I., 1986, Geologic map of the White Rock Peak quadrangle, Lincoln County, Nevada, and Beaver and Iron Counties, Utah: U.S. Geological Survey Open-File Report 86-563, scale 1:24,000.

Van Loenen, R.E., 1987, Geologic map of the Mount Grafton Wilderness Study Area, Lincoln and White Pine Counties, Nevada: U.S. Geological Survey Miscellaneous Field Studies Map MF-1938, scale 1:50,000.

Watt, J.T., and Ponce, D.A., 2007, Geophysical framework investigations influencing ground-water resources in eastcentral Nevada and west-central Utah, with a section on Geologic and geophysical basin-by-basin descriptions by Wallace, A.R. , Watt, J.T., and Ponce, D.A.: U.S. Geological Survey Open-File Report 2007-1163, 43 p., 2 plates, scale $1: 750,000$.

Welch, A.H., and Bright, D. J., eds., 2007, Water resources of the Basin and Range carbonate-rock aquifer system (BARCAS), White Pine County, Nevada, and adjacent areas in Nevada and Utah: U.S. Geological Survey Open-File Report 2007-1156, 118 p., 4 plates.

Wheeler, R.F., 1980, Geology of Sewing Machine Pass quadrangle, central Wah Wah Range, Beaver County, Utah: Brigham Young University Geology Studies v. 27, pt. 2, p. 175-191.

Whitebread, D.H., 1969, Geologic map of the Wheeler Peak and Garrison quadrangles, Nevada and Utah: U.S. Geological Survey Miscellaneous Geologic Investigations Map I-578, scale 1:48,000.

Williams, P.L., 1967, Stratigraphy and petrography of the Quichapa Group, southwestern Utah and southeastern Nevada: Seattle, Wash., University of Washington Ph.D. thesis, 139 p.

Williams, V.S., Best, M.G., and Keith, J.D., 1997, Geologic map of the Ursine-Panaca Summit-Deer Lodge area, Lincoln County, Nevada, and Iron County, Utah: U.S. Geological Survey Miscellaneous Investigations Series Map I-2479, scale 1:50,000.

Willis, J.B., Best, M.G., Kowallis, B.J., and Best, V.C., 1987, Preliminary geologic map of northern Wilson Creek Range, Lincoln County, Nevada: U.S. Geological Survey Miscellaneous Field Studies Map MF-1971, scale 1:50,000.

Winograd, I.J., and Thordarson, W., 1975, Hydrogeologic and hydrochemical framework, south-central Great Basin, Nevada-California, with special reference to the Nevada Test Site: U.S. Geological Survey Professional Paper 712-C, p. 126.

Workman, J.B., Menges, C.M., Page, W.R., Ekren, E.B., Rowley, P.D., and Dixon, G.L., 2002, Tectonic map of the Death Valley ground-water model area, Nevada and California: U.S. Geological Survey Miscellaneous Field Studies Map MF-2381-B, scale 1:350,000, 1 pl. with pamphlet. 


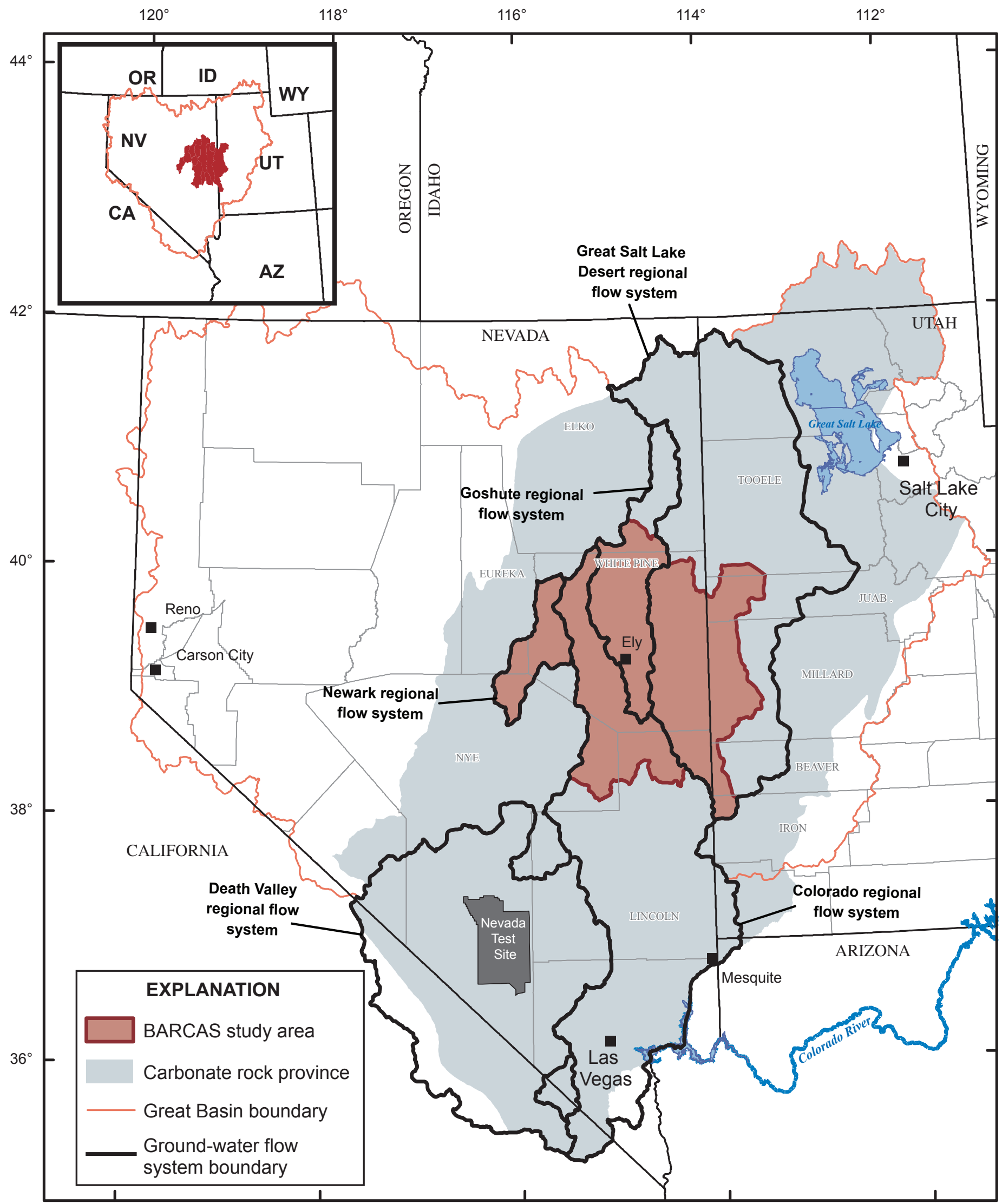

Base from USGS 1:100,000-scale digital data, 1979-1984.

1:1,000,000 scale watershed boundaries from USGS digital data.

Universal Transverse Mercator Projection, Zone 11, NAD83.

Figure 1. Carbonate rock province, BARCAS study area, and associated regional ground-water flow systems. 


\section{After ash-flow eruption and caldera collapse}

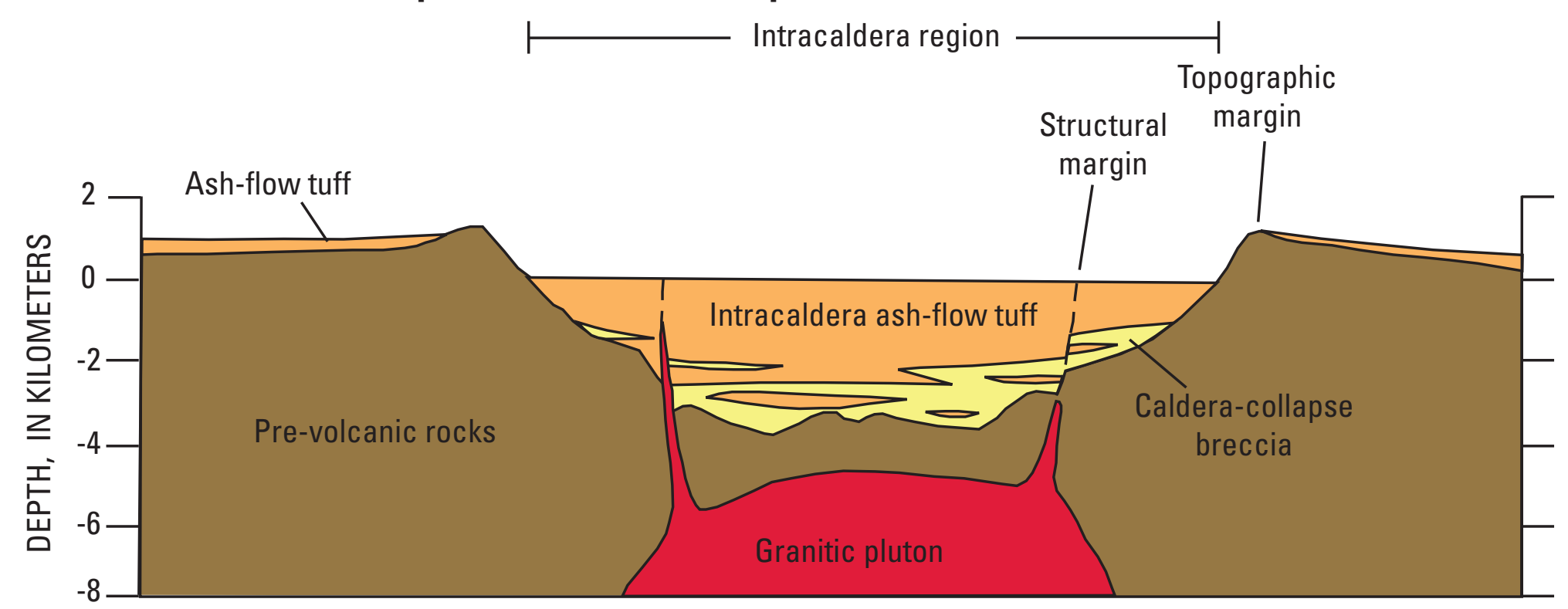

After resurgence and post-caldera deposition

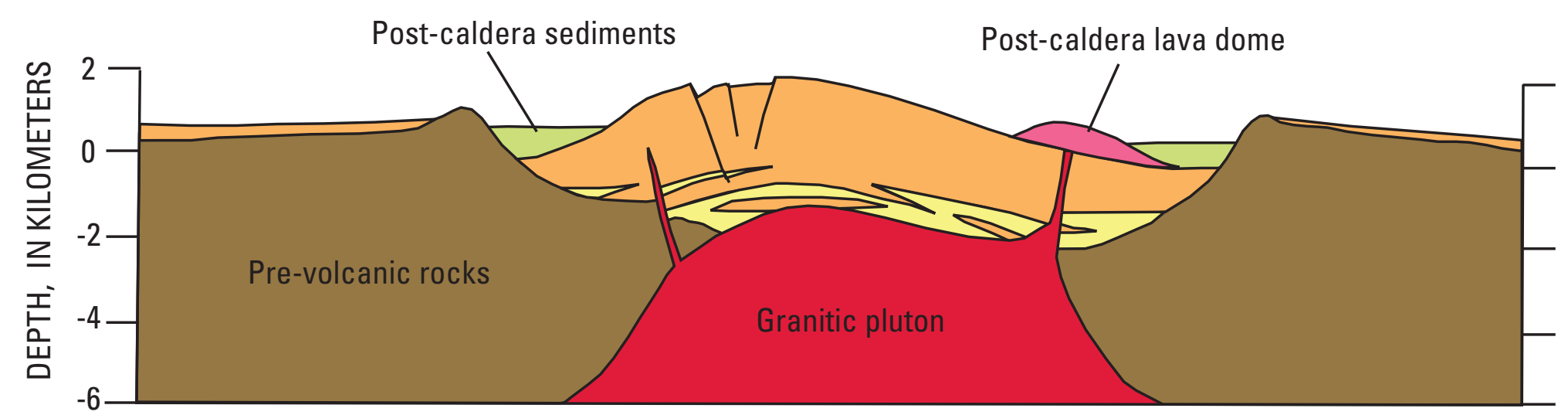

No vertical exaggeration; scale approximate.

Figure 2. Generalized diagram of ash-flow caldera. Diagram modified from Lipman (1984) 


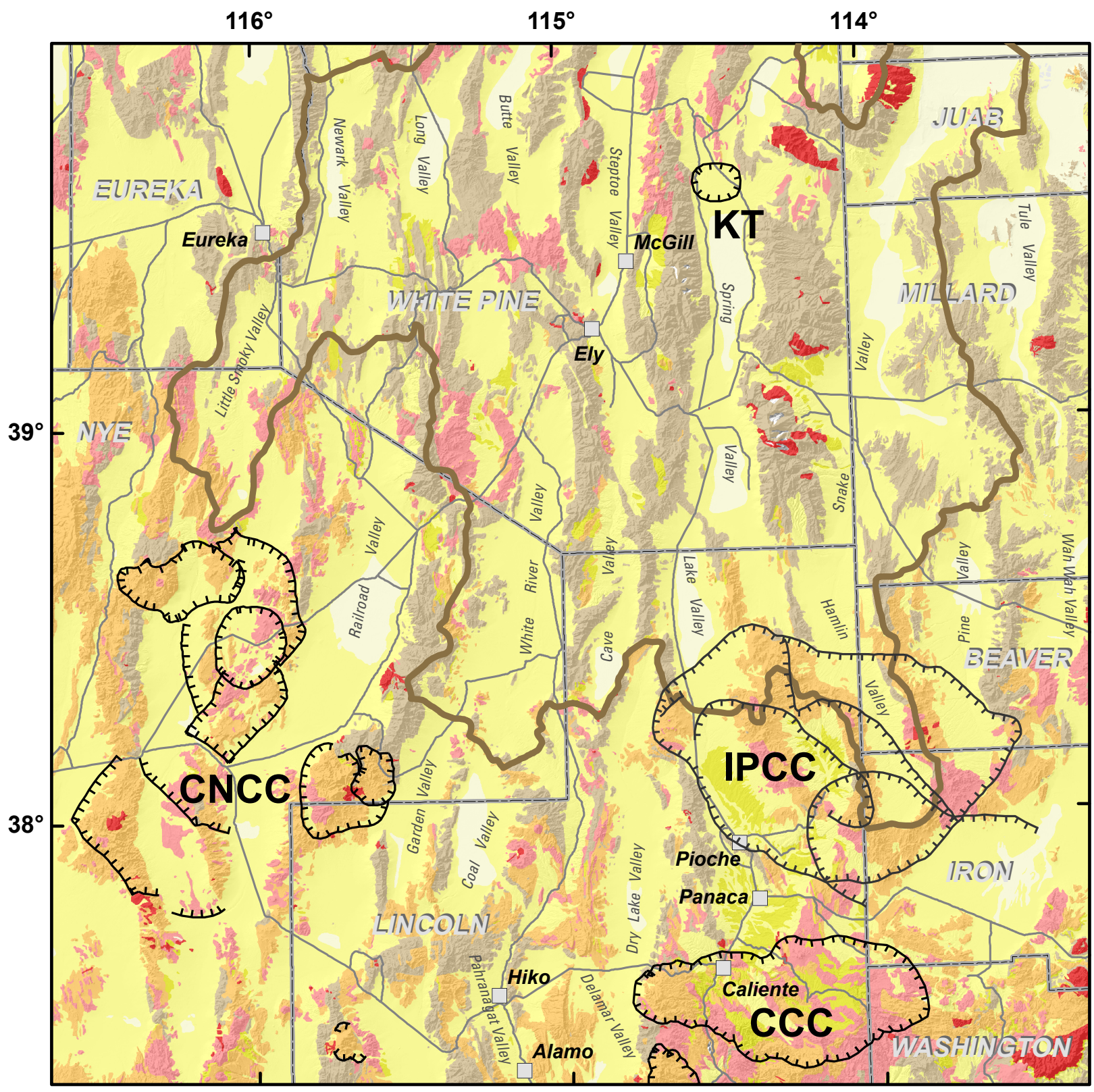

\section{EXPLANATION}

Nevada geology modified from Stewart and others (2003) Utah geology modified from Hintze and others (2000)

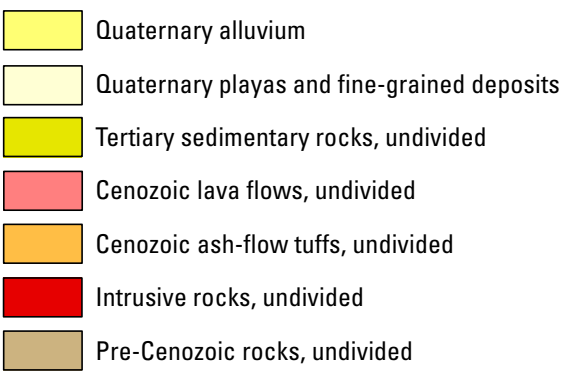

ताIT Caldera boundary

Caldera boundaries modified from Williams and others (1997) Loucks and others (1989), Raines and others (1996), Workman and others (2002), and Gans and others (1989)

CCC, Caliente caldera complex; CNCC, central Nevada caldera complex; IPCC, Indian Peak caldera complex; KT, inferred
source of the Kalamazoo Tuff

Roads

BARCAS study area boundary

$---=$ County boundary

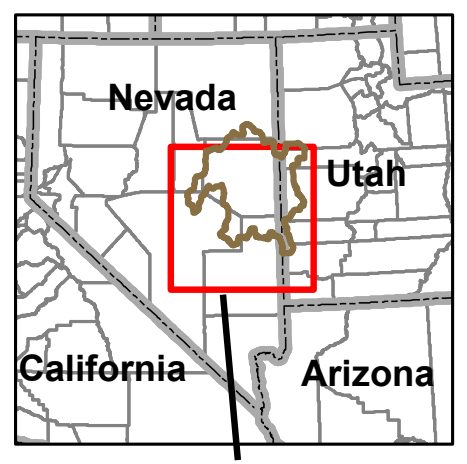

Area shown in figure

Base from USGS 1:100,000-scale digital data, 1979-1984.

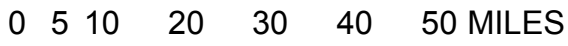

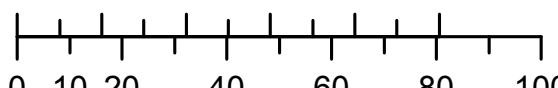

Figure 3. Generalized geology map and locations of calderas, eastern Nevada and western Utah.

01020

4060

80

100 KILOMETERS 


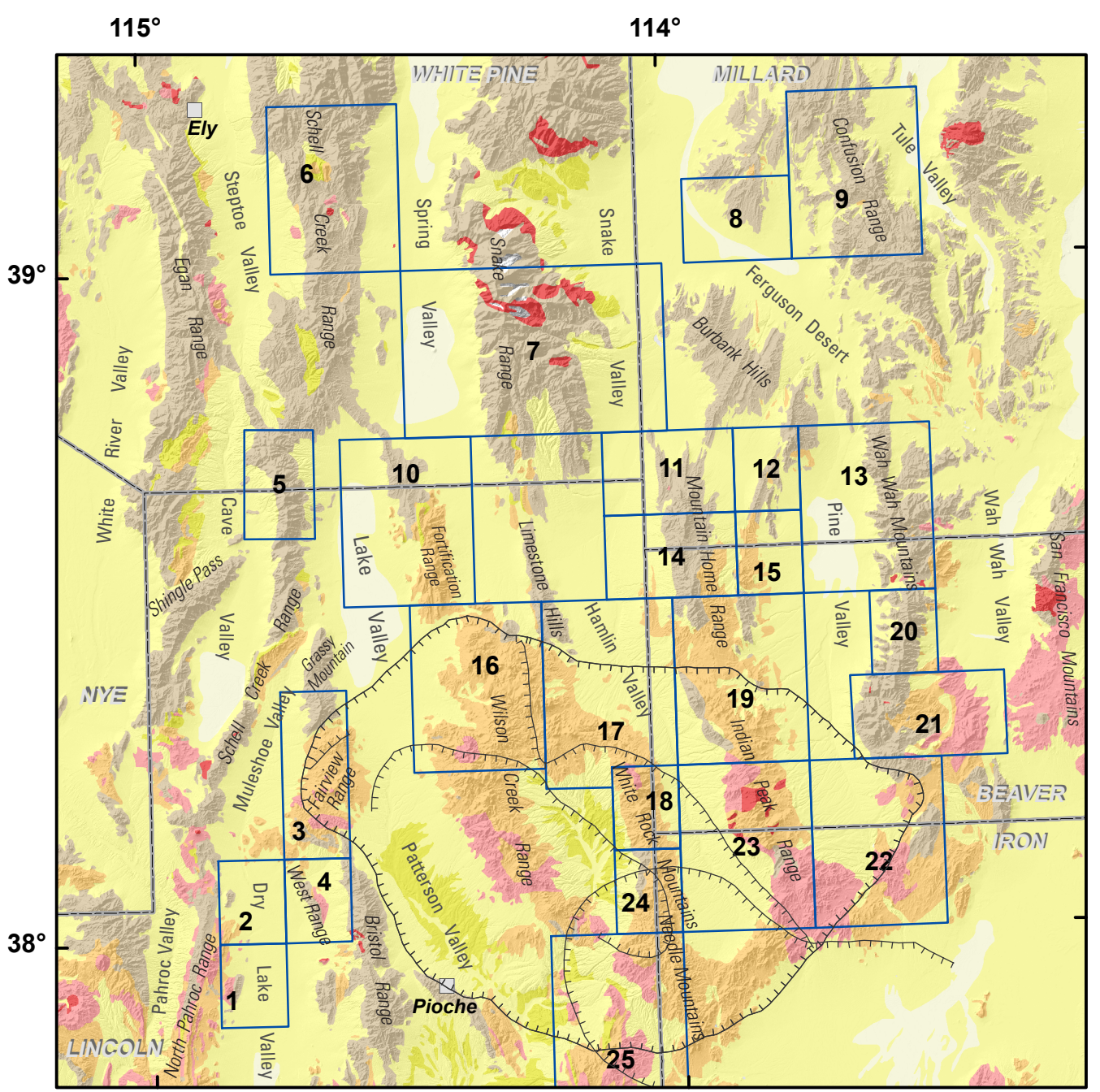

\section{EXPLANATION}

Nevada geology modified from Stewart and others (2003); Utah geology modified after Hintze and others (2000)

$\square$ Quaternary alluvium

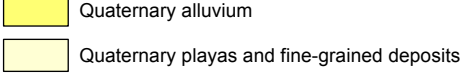

Tertiary sedimentary rocks, undivided

Cenozoic lava flows, undivided

Cenozoic ash-flow tuffs, undivided

Intrusive rocks, undivided

Pre-Cenozoic rocks, undivided

पाTा Caldera boundary

Caldera boundaries modified from Williams and others (1997). Loucks and others (1989), Raines and others (1996), Workman and

----- County boundary
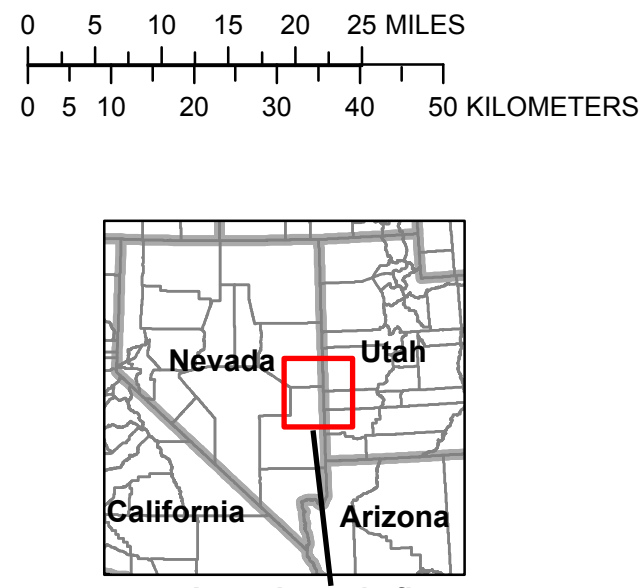

Area shown in figure
9 Maps used for thickness compilation

Author

number

Swadley and others, 1994

Ekren and Page, 1995

Best and others, 1998

Page and Ekren, 1995

Van Loenen, 1987

Drewes, 1967

Whitebread, 1969

Hose, 1965

Hintze, 1974a

Loucks and others, 1989

Hintze, 1986

Hintze, 1981

Hintze, 1974b

Hintze and Best, 1987

Best and Hintze, 1980

Willis and others, 1987

Best, Toth, and others, 1989

Toth, 1986

Best, Hintze, and Homes,

1987

Wheeler, 1980

Abbott and others, 1983

Best, Morris, and others, 1987

Best, Grant, and others, 1987

Keith and others, 1994

Williams and others, 1997

Base from USGS 1:100,000-scale digital data, 1979-1984.

Figure 4. Index of geologic maps in the vicinity of the Indian Peak caldera complex used to compile volcanic rock thicknesses. 


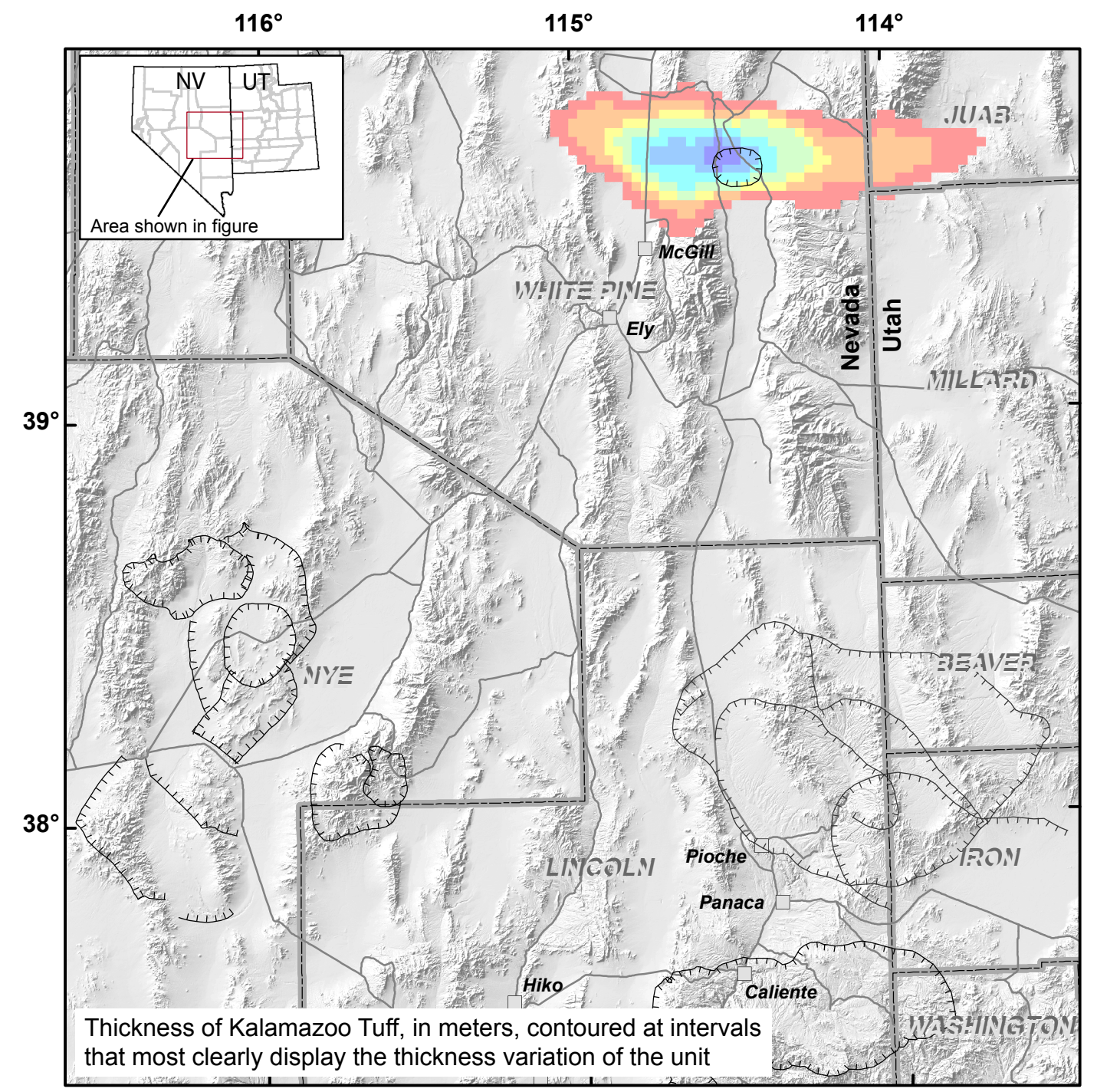

Base from USGS 1:100,000-scale digital data, 1979-1984.
Universal Transverse Mercator Projection, zone 11, NAD83.

\section{EXPLANATION}

\section{Kalamazoo Tuff, thickness in meters}

Contoured from thickness data in Gans and others (1989)

\begin{tabular}{|c|c|}
\hline $0-50$ & Гामा Caldera boundary \\
\hline $51-100$ & $\begin{array}{l}\text { Caldera boundaries modified from Williams and others (1997), } \\
\text { Loucks and others (1989), Raines and others (1996). Workman and }\end{array}$ \\
\hline $101-150$ & others (2002), and Gans and others (1989) \\
\hline $151-200$ & Roads \\
\hline $201-250$ & $=---=$ County boundary \\
\hline $251-300$ & \\
\hline $301-350$ & 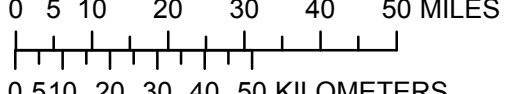 \\
\hline
\end{tabular}

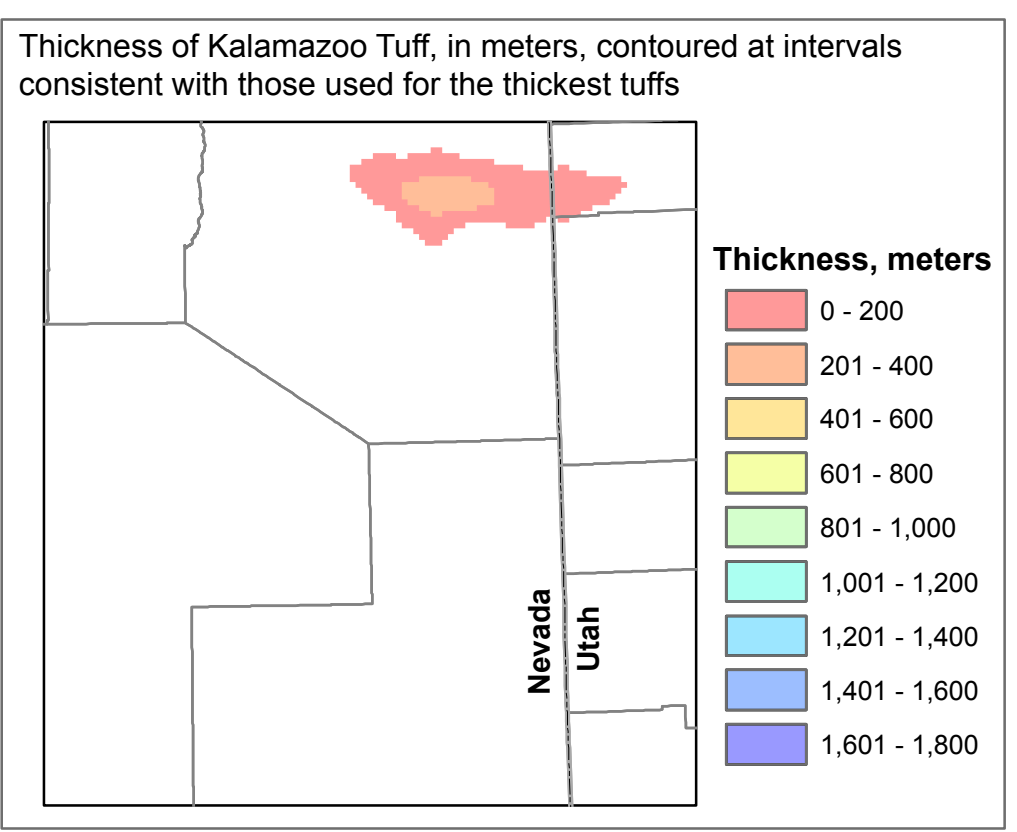

Figure 5. Thickness (isopach) map of Kalamazoo Tuff from Gans and others (1989). 


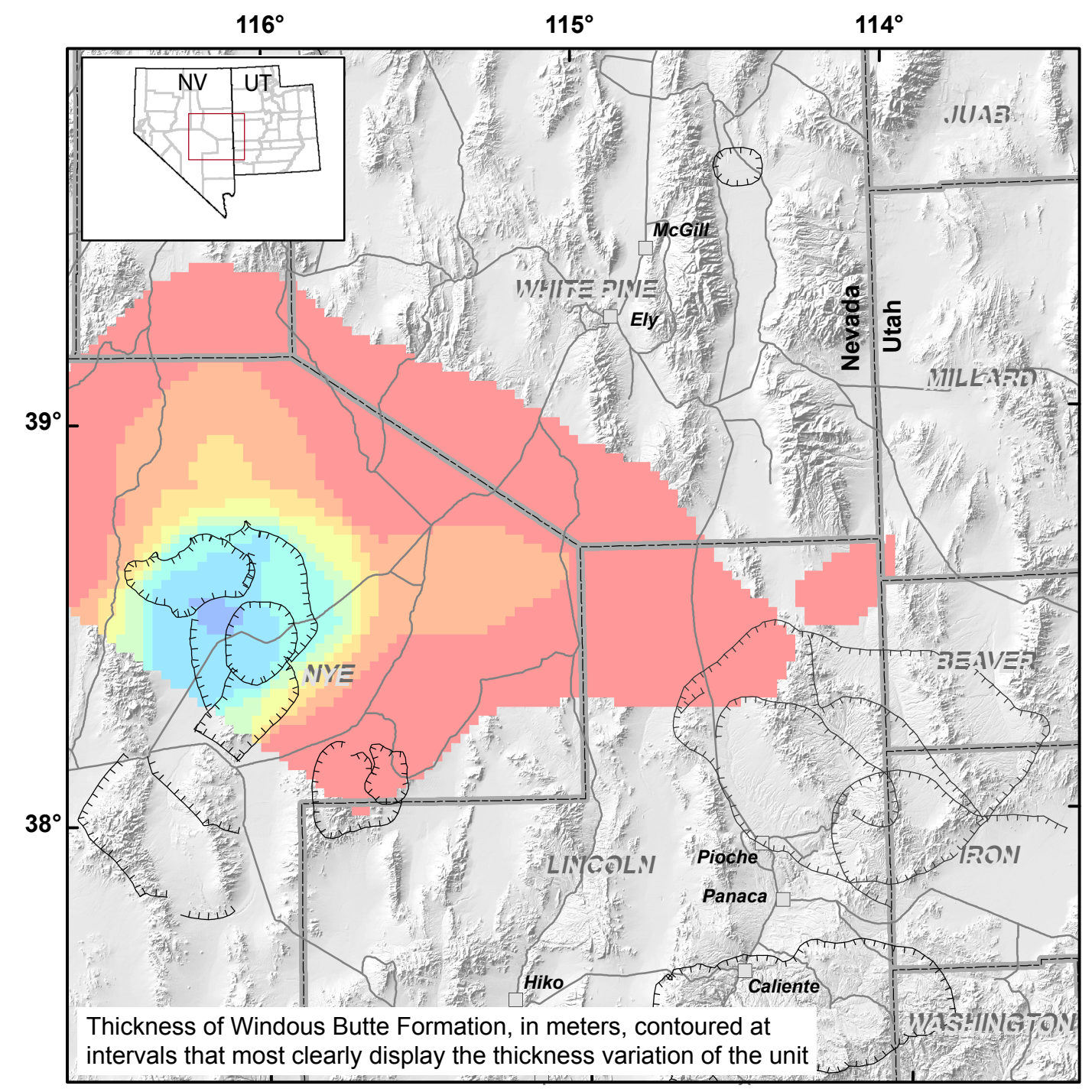

Base from USGS 1:100,000-scale digital data, 1979-1984.
Universal Transverse Mercator Projection, zone 11, NAD83.

\section{EXPLANATION}

\section{Windous Butte Formation, thickness in meters}

Contoured from thickness data in Best, Christiansen, and others (1989)

\begin{tabular}{|c|c|}
\hline $0-200$ & חा+ा Caldera boundary \\
\hline $201-400$ & \multirow{2}{*}{$\begin{array}{l}\text { Caldera boundaries modified from Williams and others (1997), } \\
\text { Loucks and others (1989), Raines and others (1996), Workman and } \\
\text { others (2002), and Gass and others (1989) }\end{array}$} \\
\hline $401-600$ & \\
\hline $601-800$ & \multirow{3}{*}{$\begin{array}{l}- \text { Roads } \\
---=\text { County boundary }\end{array}$} \\
\hline $801-1,000$ & \\
\hline $1,001-1,200$ & \\
\hline $1,201-1,400$ & \multirow{3}{*}{ 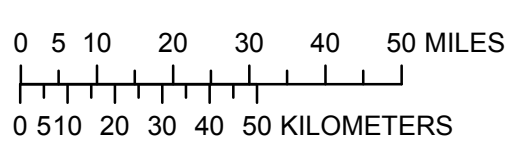 } \\
\hline $1,401-1,600$ & \\
\hline $1,601-1,800$ & \\
\hline
\end{tabular}

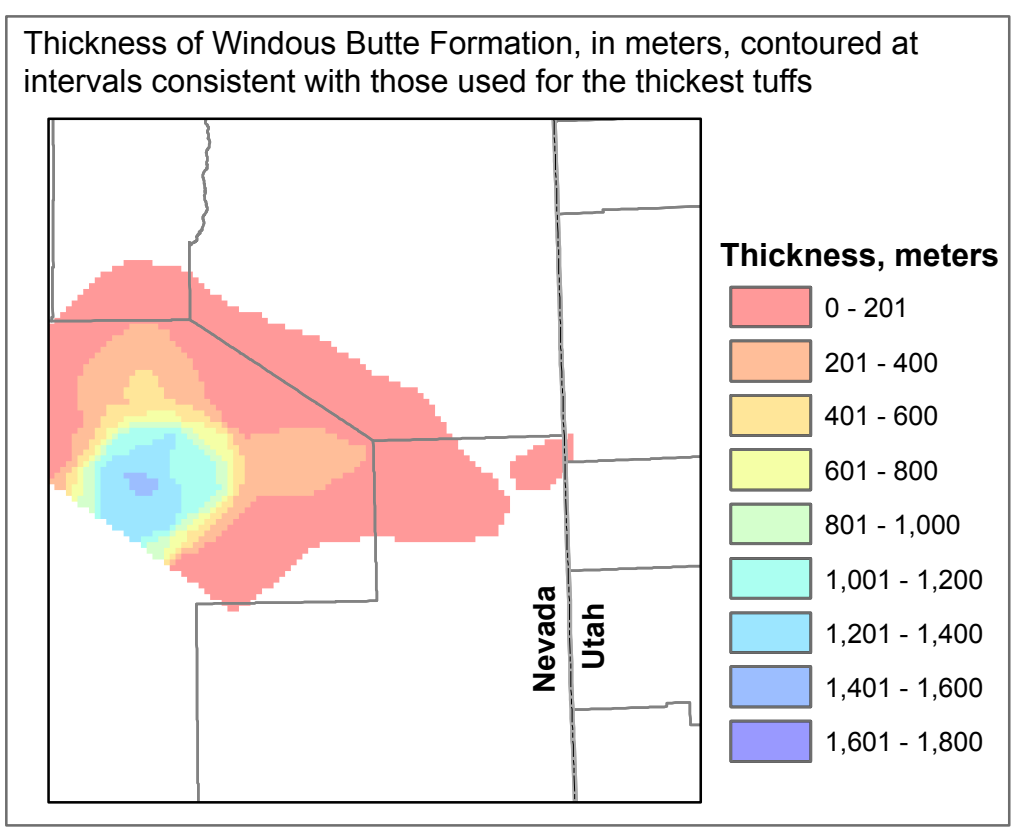

Figure 6. Thickness (isopach) map of Windous Butte Formation. 


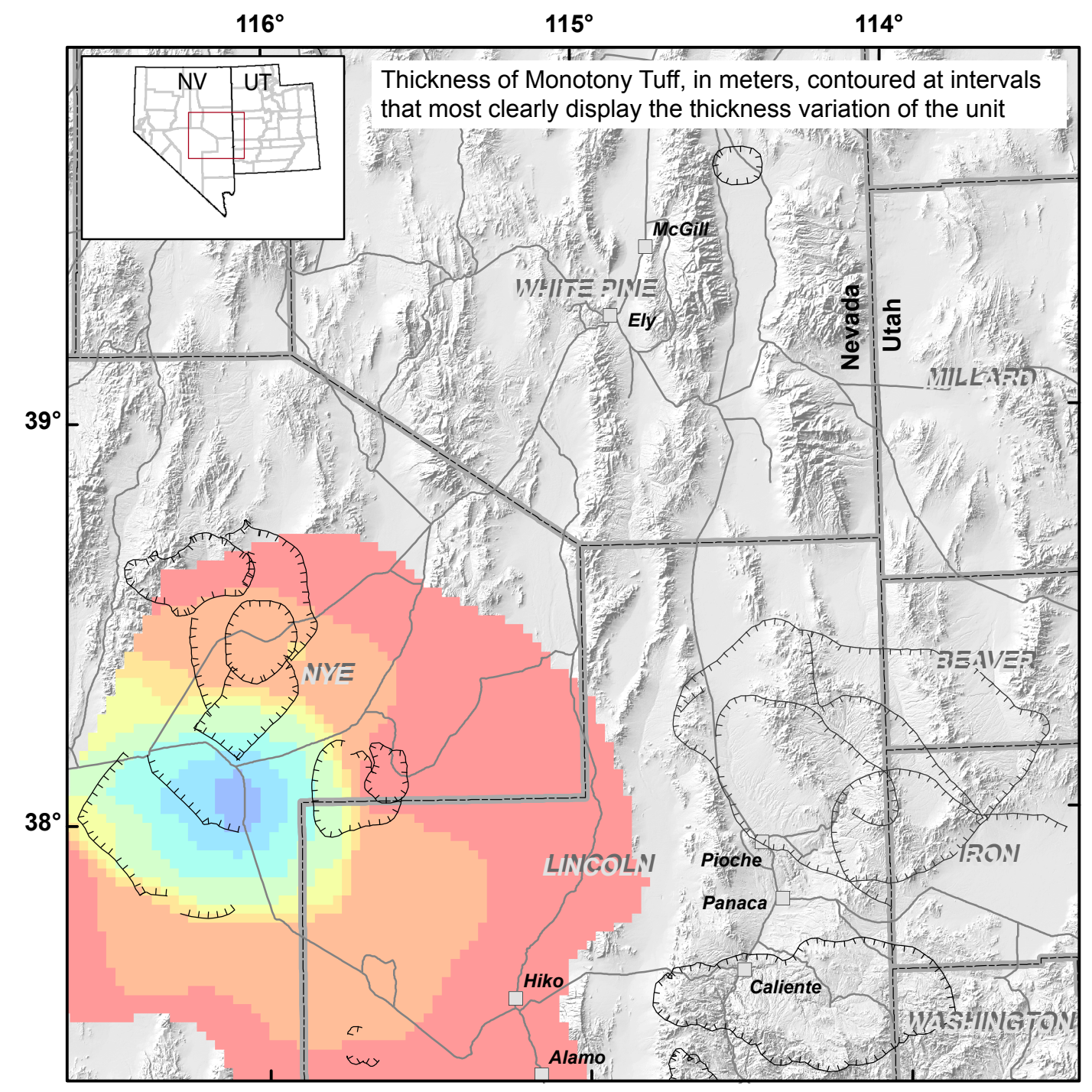

Base from USGS 1:100,000-scale digital data, 1979-1984.
Universal Transverse Mercator Projection, zone 11, NAD83.

\section{EXPLANATION}

\section{Monotony Tuff, thickness in meters}

Contoured from thickness data in Best, Christiansen, and others (1989)

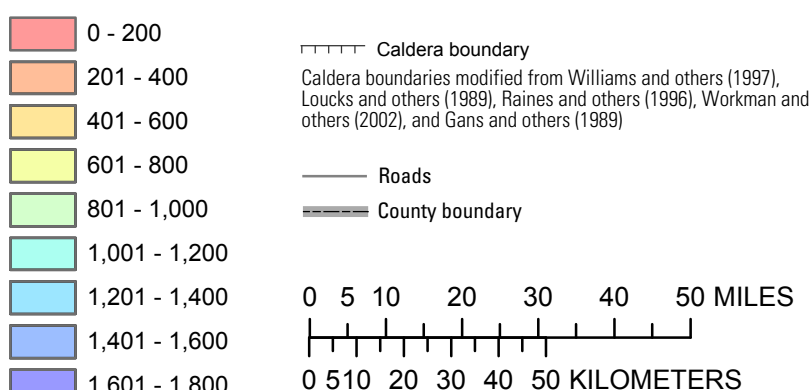

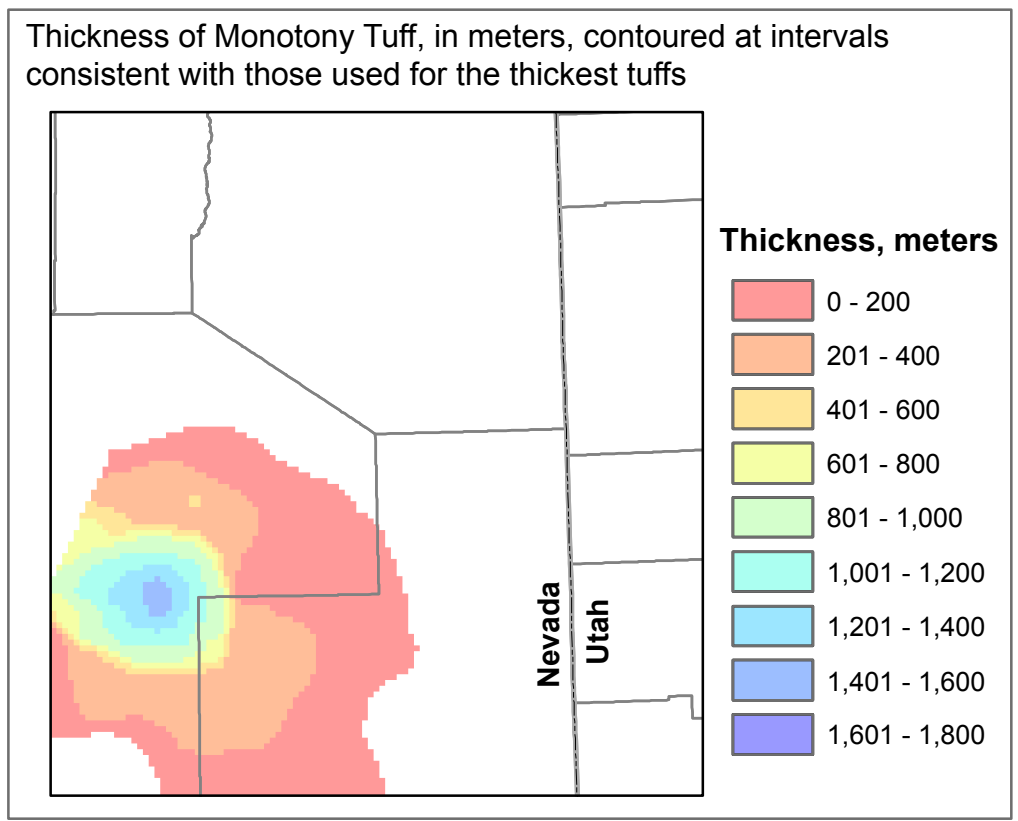

Figure 7. Thickness (isopach) map of Monotony Tuff. 


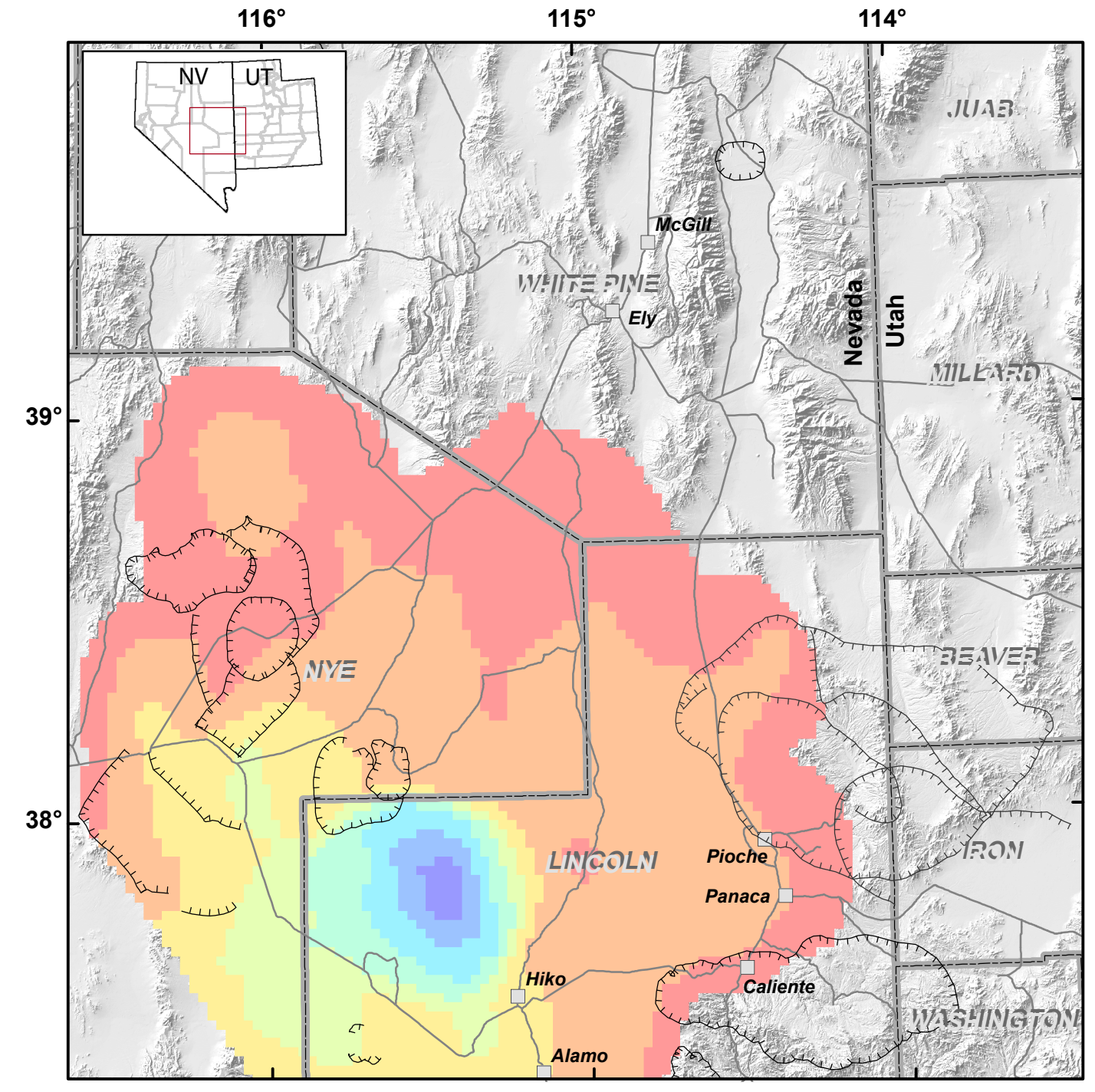

Base from USGS 1:100,000--scale digital data, 1979-1984.
Universal Transverse Mercator Projection, Zone 11, NAD83.

\section{EXPLANATION}

Shingle Pass Tuff, thickness in meters

Contoured from thickness data in Best. Christiansen, and others (1989)

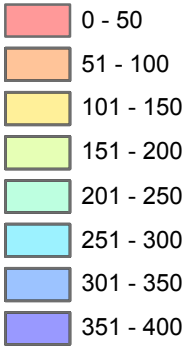

ПTाए Caldera boundary

Caldera boundaries modified from Williams and others (1997),
Loucks and others (1989) Raines and others (1996). Workman others (2002), and Gans and others (1989)

- Roads

----- County boundary

$\begin{array}{lllllll}0 & 5 & 10 & 20 & 30 & 40 & 50\end{array}$

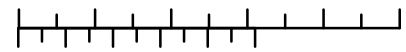

051020304050 KILOMETERS

Thickness of Shingle Pass Tuff, in meters, contoured at intervals consistent with those used for the thickest tuffs

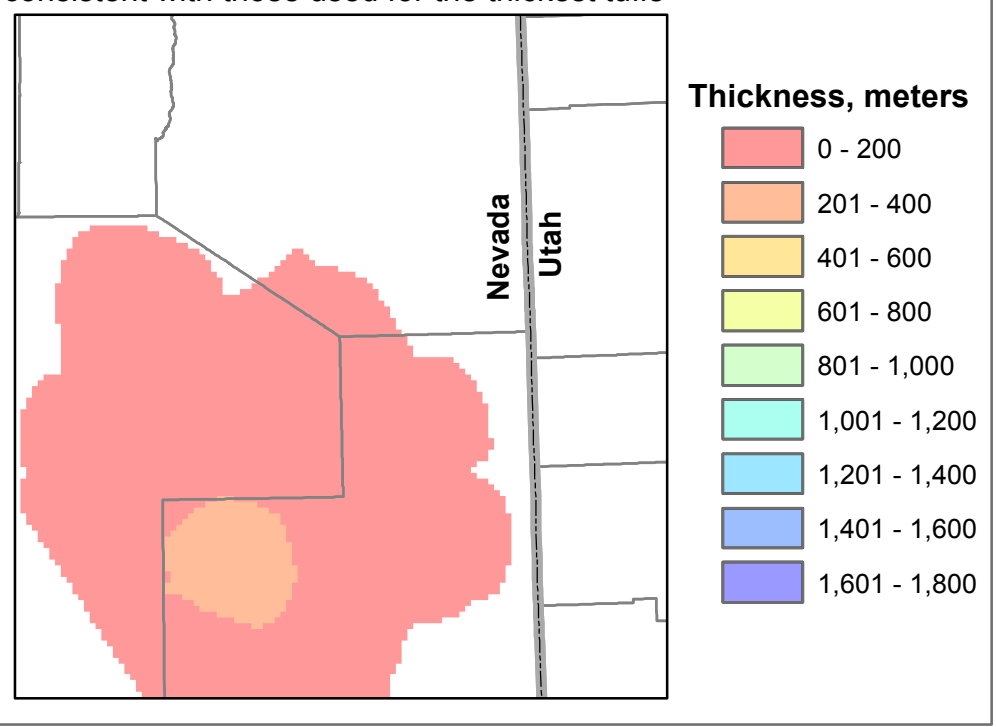

Figure 8. Thickness (isopach) map of Shingle Pass Tuff 


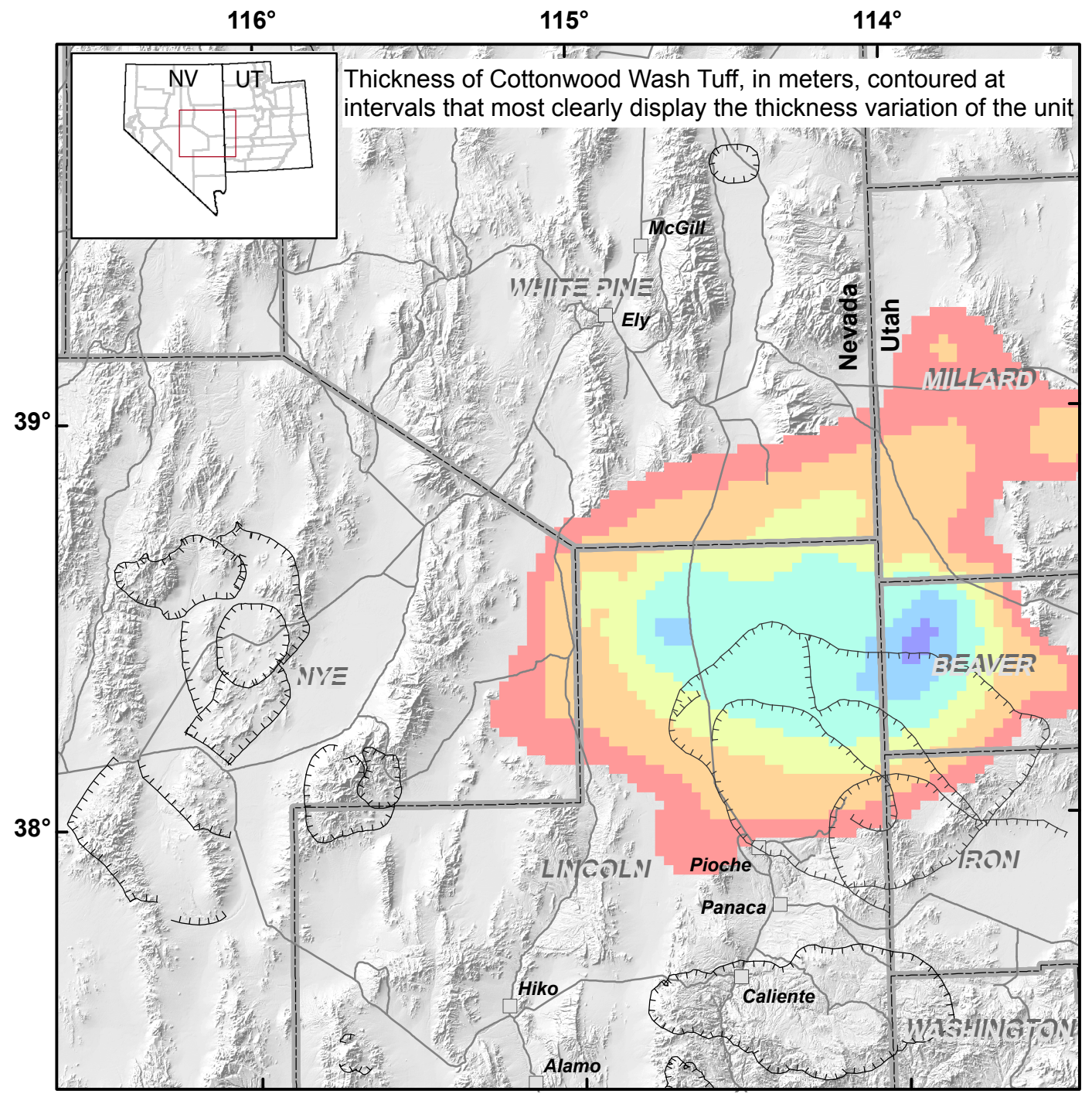

Base from USGS 1:100,000-scale digital data, 1979-1984.
Universal Transverse Mercator Projection, zone 11, NADB3.

\section{EXPLANATION}

\section{Cottonwood Wash Tuff, thickness in meters}

Contoured from thickness data in Best, Christiansen, and Blank (1989)

\begin{tabular}{|c|c|}
\hline $0-50$ & T11T Caldera boundary \\
\hline $51-100$ & $\begin{array}{l}\text { Caldera boundaries modified from Williams and others (1997), } \\
\text { Loucks and others (1989), Raines and others (1996), Workman and } \\
\text { others (2002) and Gans and others (1989) }\end{array}$ \\
\hline $101-150$ & \\
\hline $151-200$ & Roads \\
\hline $201-250$ & County Doundary \\
\hline $251-300$ & 50 MILES \\
\hline
\end{tabular}

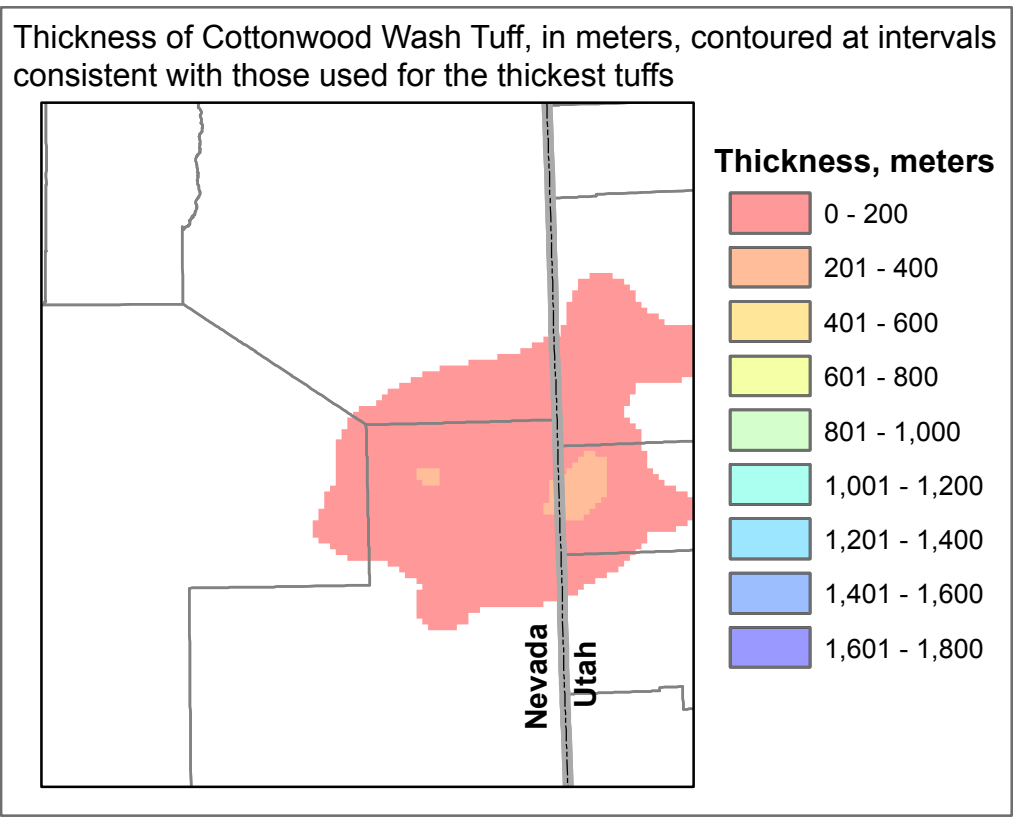

Figure 9. Thickness (isopach) map of Cottonwood Wash Tuff 


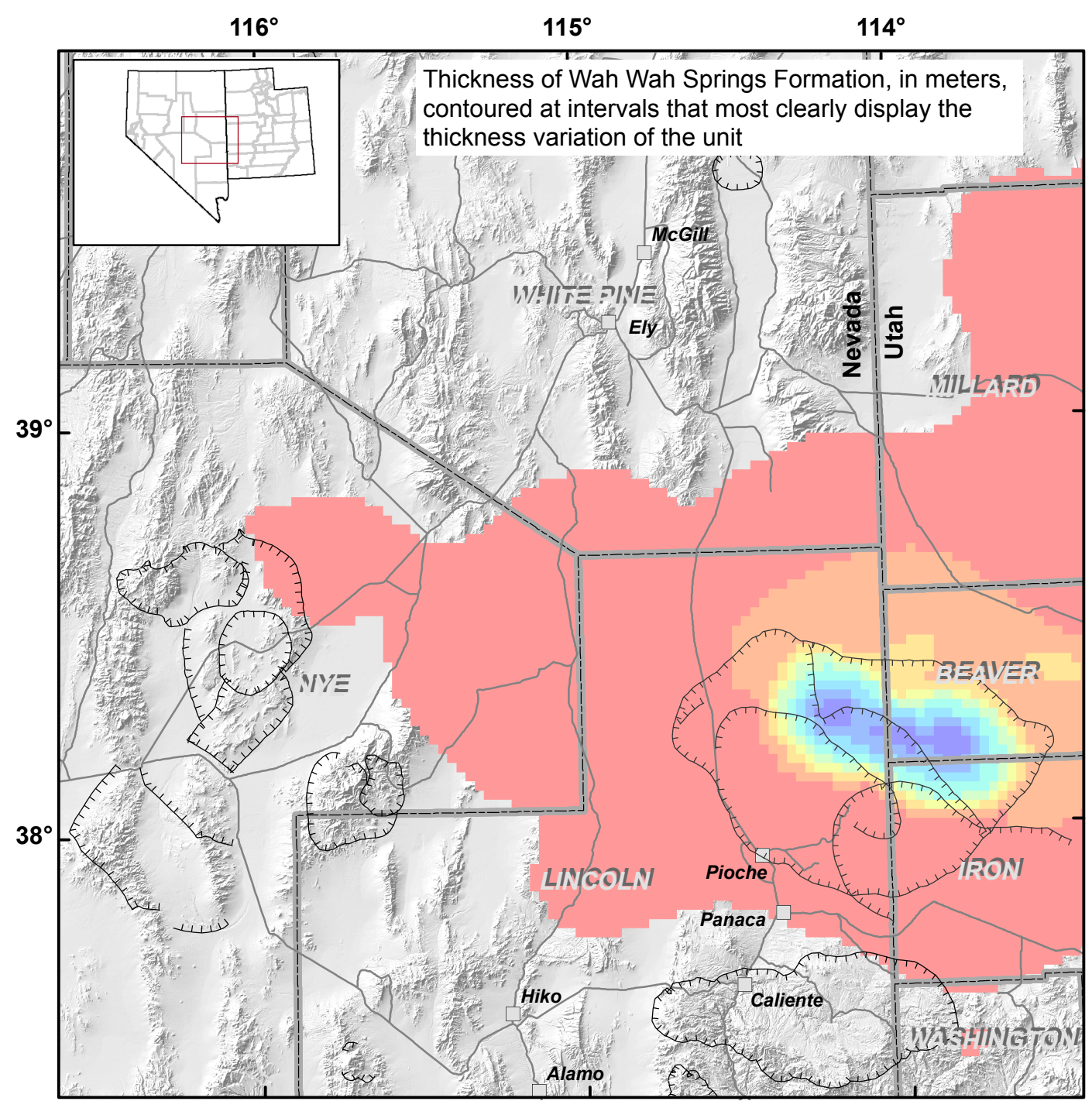

Base from USGS 1:100,000-scale digital data, 1979-1984.
Universal Transverse Mercator Projection, zone 11, NADB3.

\section{EXPLANATION}

Wah Wah Springs Formation, thickness in meters

Contoured from thickness data in Best, Christiansen, and Blank (1989)

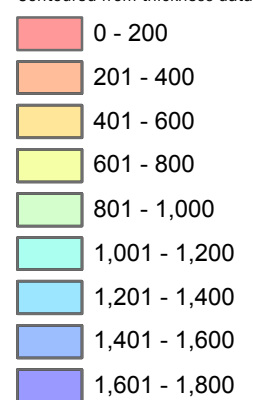

TIIT Caldera boundary

Caldera boundares nes and others (1996), Workman an others (2002), and Gans and others (1989).

Roads

----- County boundary

$\begin{array}{lllllll}0 & 5 & 10 & 20 & 30 & 40 & 50\end{array}$ MILES

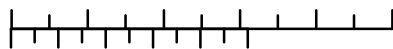

051020304050 KILOMETERS

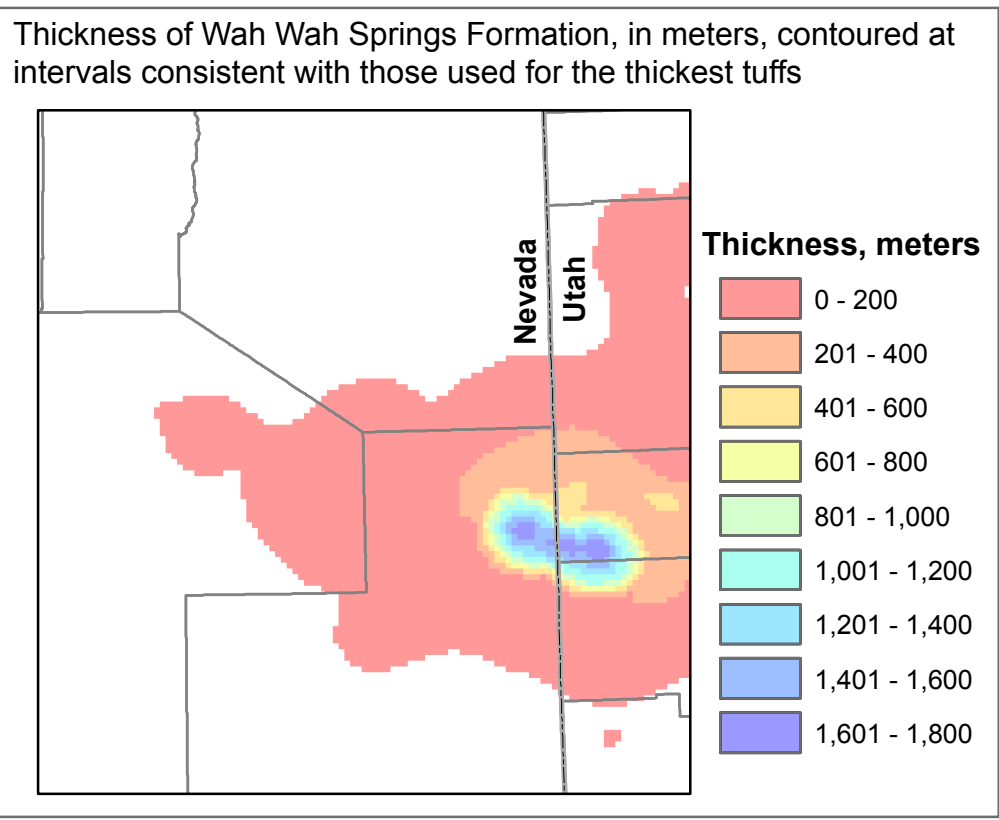

Figure 10. Thickness (isopach) map of Wah Wah Springs Formation. 


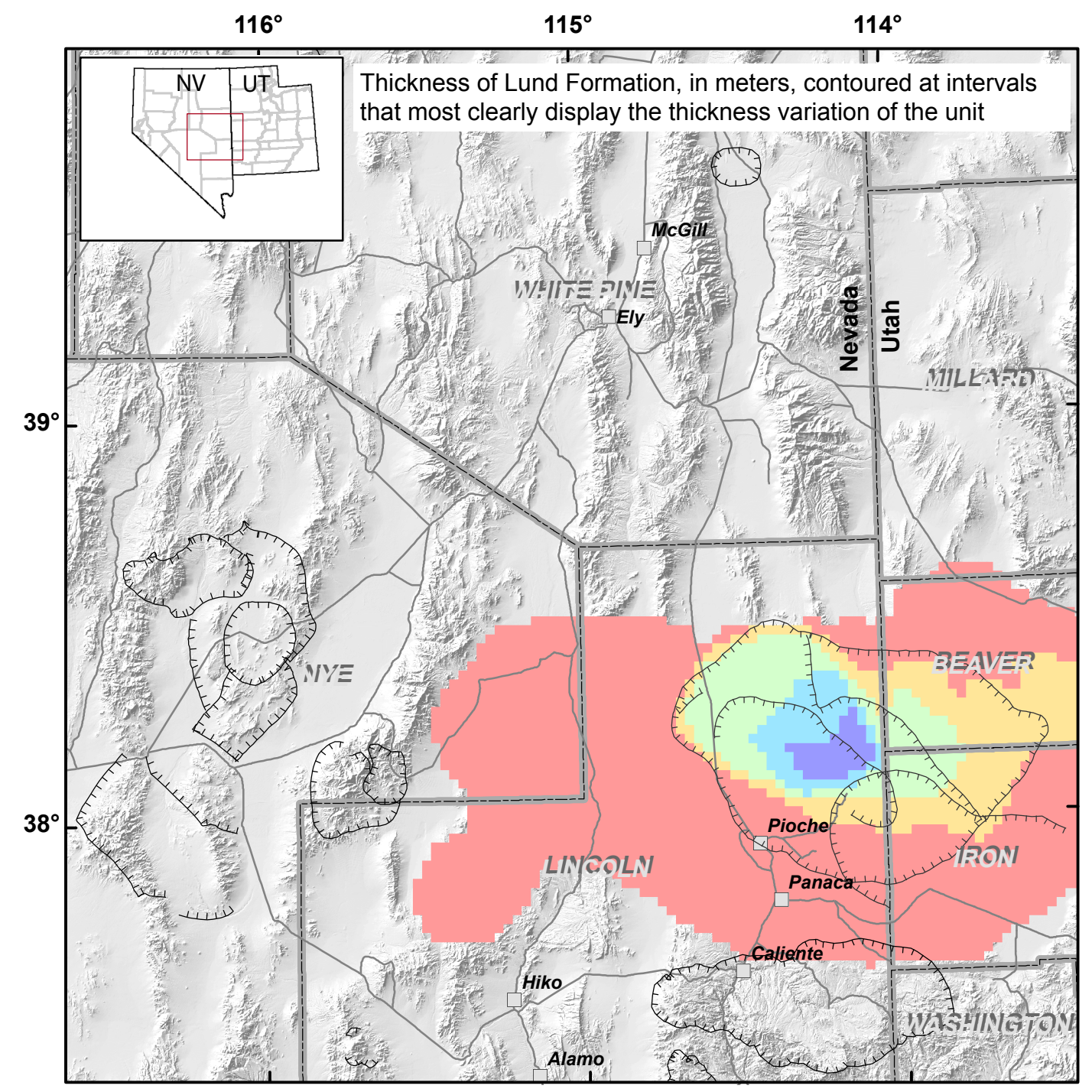

Base from USGS 1:100,000-scale digital data, 1979-1984.
Universal Transverse Mercator Projection, zone 11, NAD83.

\section{EXPLANATION}

Lund Formation, thickness in meters

Contoured from thickness data in Best, Christiansen, and Blank (1989)

\begin{tabular}{|c|c|}
\hline $0-200$ & TाTा Caldera boundary \\
\hline $201-400$ & $\begin{array}{l}\text { Caldera boundaries moddfied from Williams and others (1997), } \\
\text { Loucks and others (1989), , inaines and others (1996), Workman and }\end{array}$ \\
\hline $401-600$ & \\
\hline $601-800$ & Roads \\
\hline $801-1,000$ & County boundary \\
\hline & 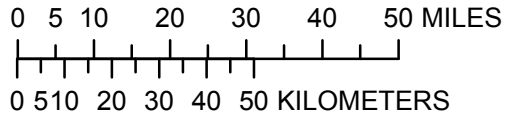 \\
\hline
\end{tabular}

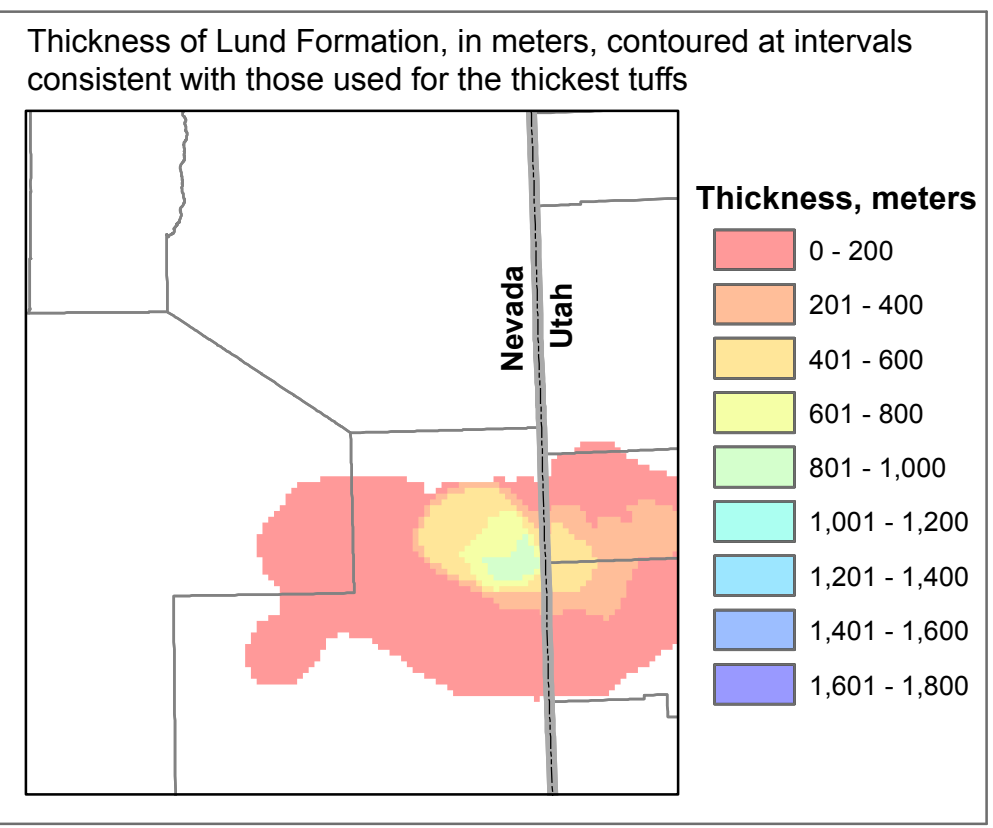

Figure 11. Thickness (isopach) map of Lund Formation. 


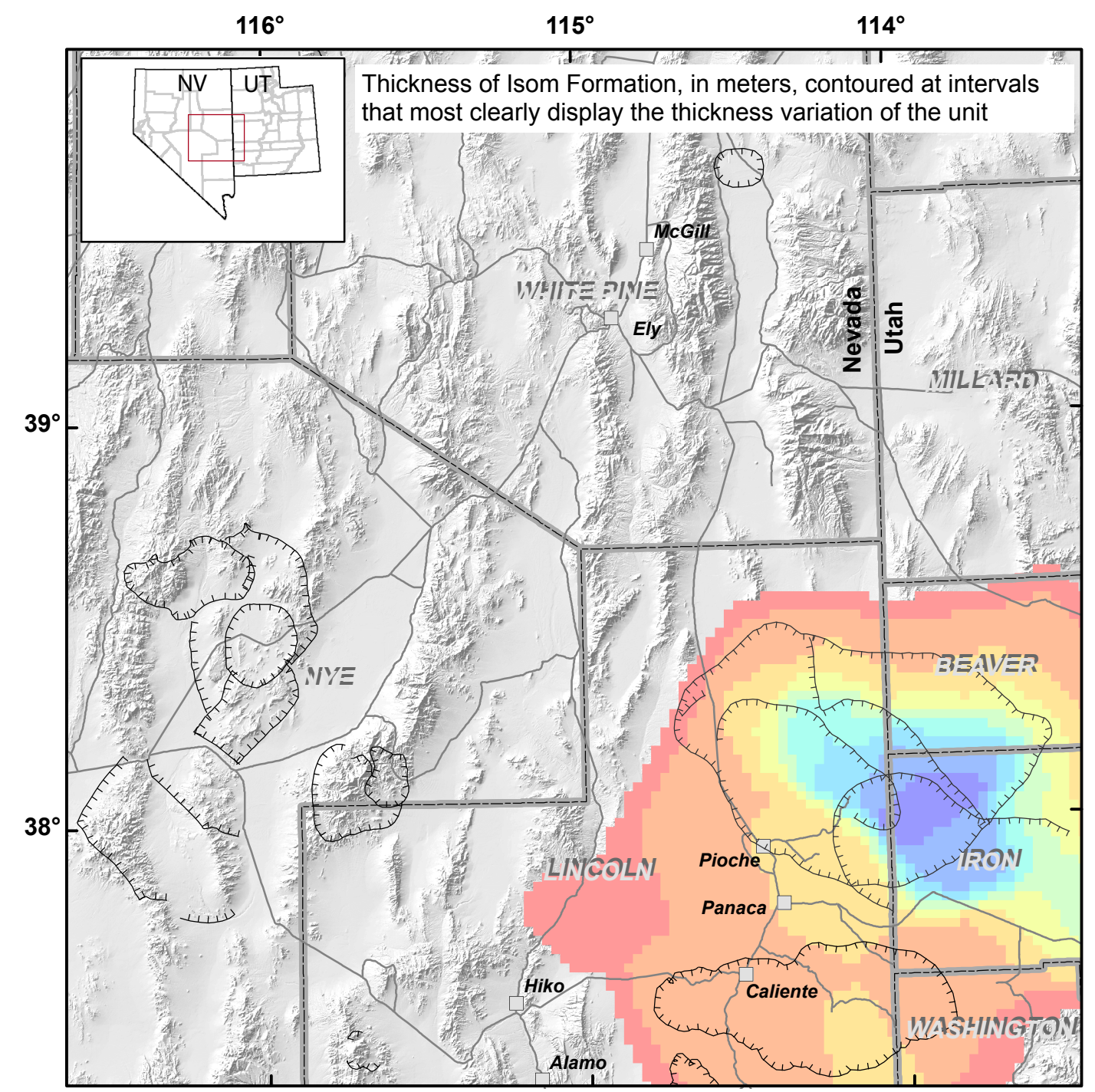

Base from USGS 1:100,000-scale digital data, 1979-1984.
Universal Transverse Mercator Projection, zone 11, NAD83.

\section{EXPLANATION}

Isom Formation, thickness in meters

Contoured from thickness data in Best, Christiansen, and Blank (1989)

$10-50$

$\square 51-100$

$101-150$

$151-200$

$201-250$

$251-300$

$301-350$

$351-400$

$401-467$

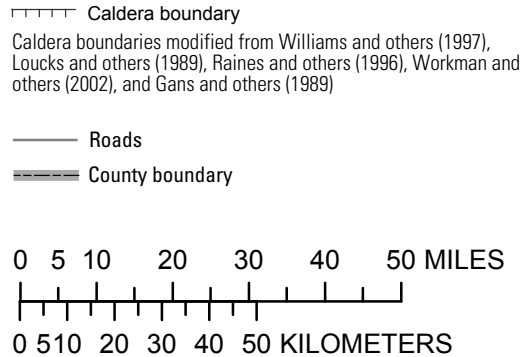

Thickness of Isom Formation, in meters, contoured at intervals consistent with those used for the thickest tuffs

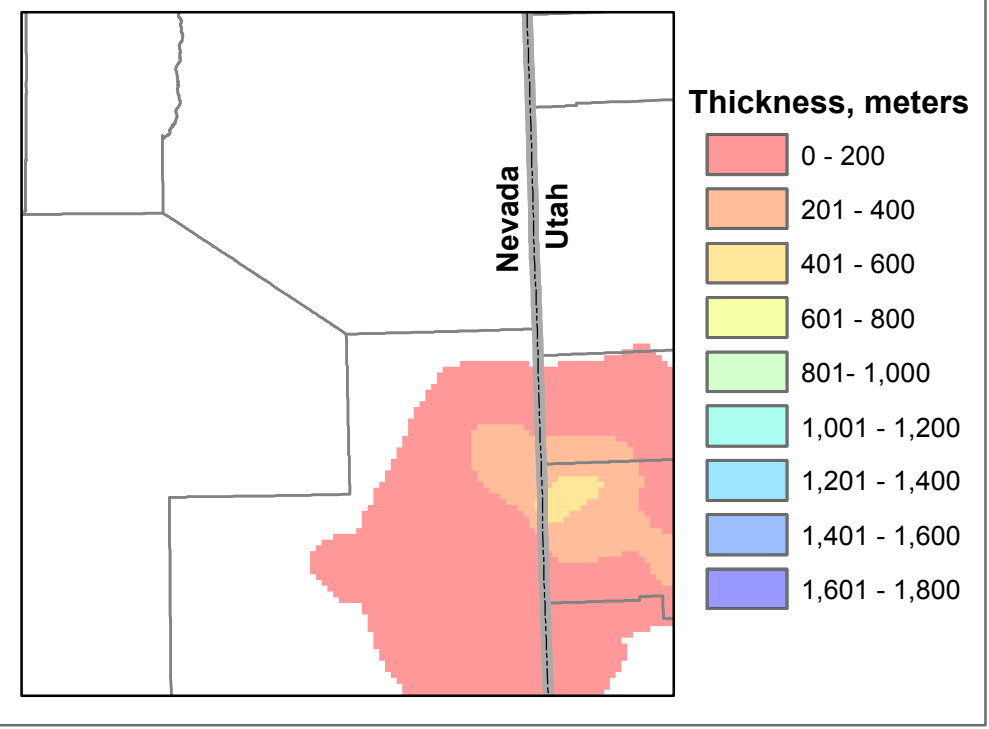

Figure 12. Thickness (isopach) map of Isom Formation. 


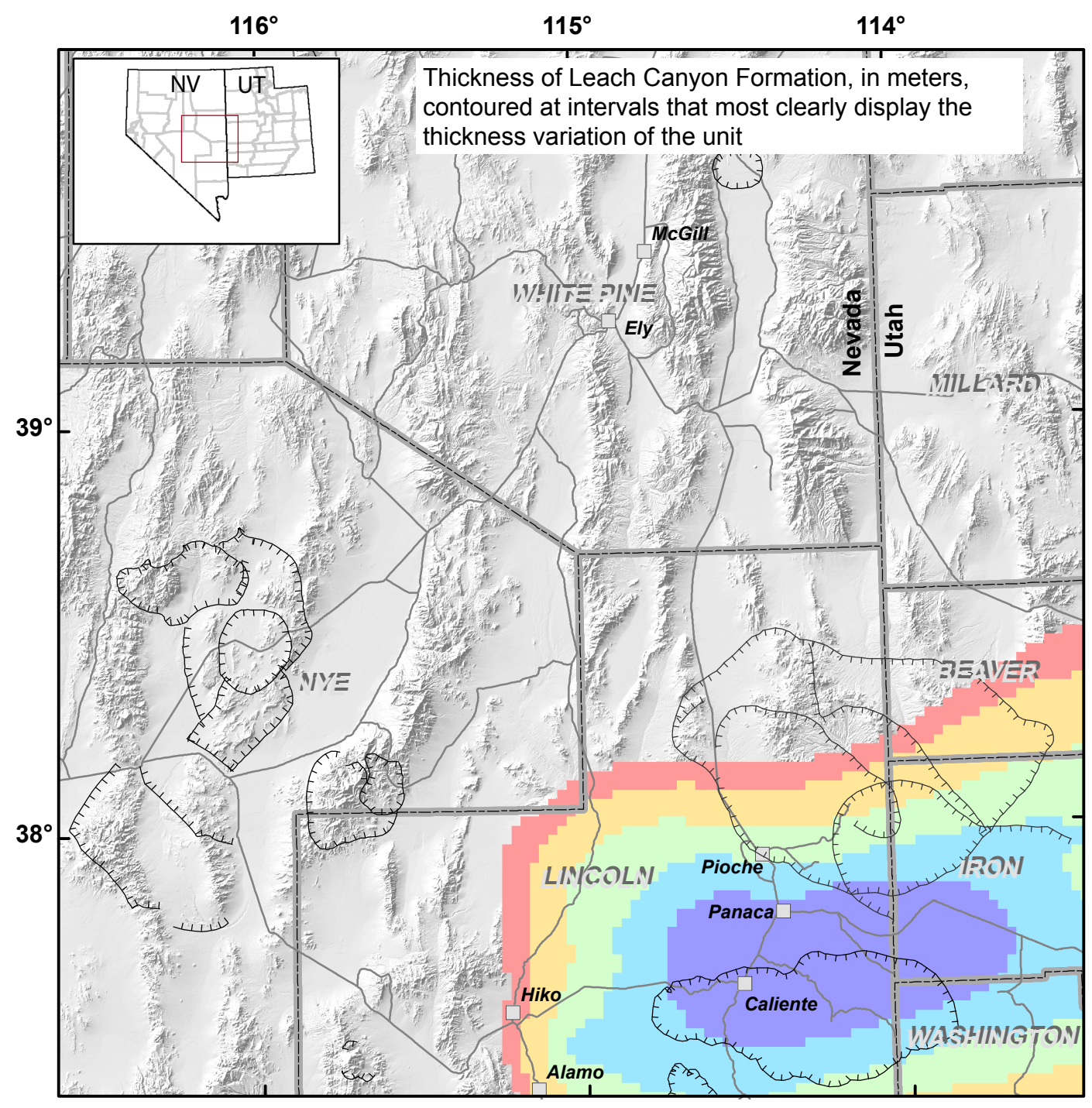

Base from USGS 1:100,000-scale digital data, 1979-1984.
Universal Transverse Mercator Projection, zone 11, NAD83.

\section{EXPLANATION}

Leach Canyon Formation, thickness in meters

Contoured from thickness data in Williams (1967)

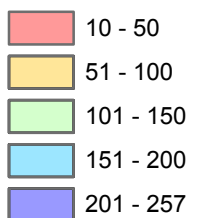

Caldera boundaries modified from Williams and others (1997), Loucks and others (1989), Raines and others (1996), Workman and others (2002), and Gans and others (1989)

Roads

$=---$ County boundary
$\begin{array}{lllllll}0 & 5 & 10 & 20 & 30 & 40 & 50\end{array}$

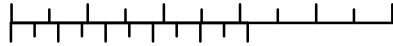
051020304050 KILOMETERS

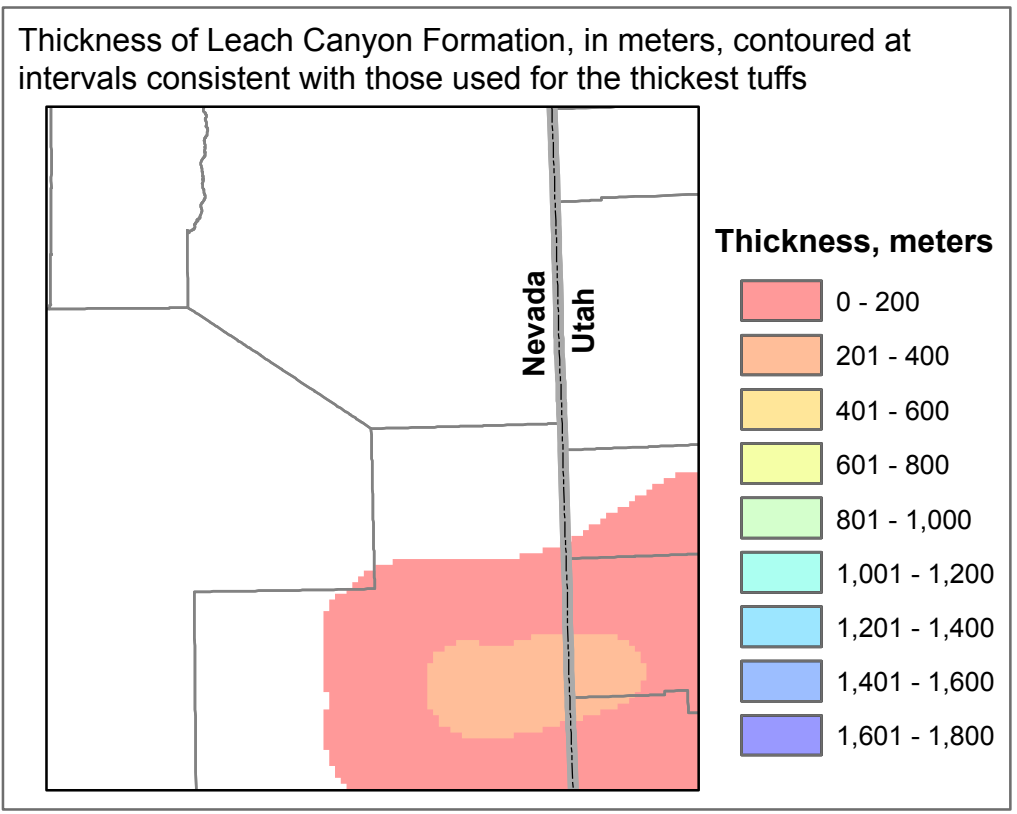

Figure 13. Thickness (isopach) map of Leach Canyon Formation. 


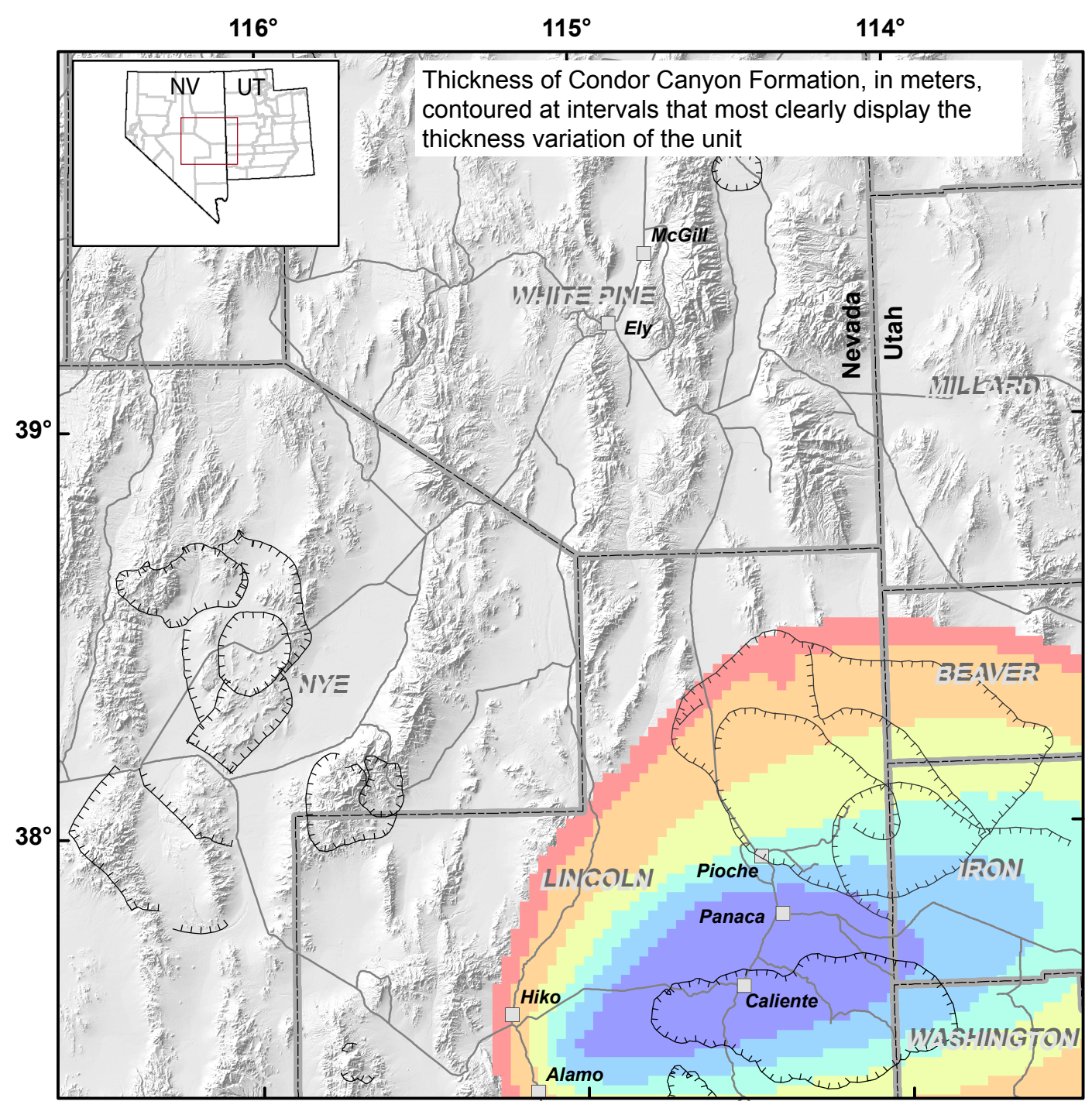

Base from USGS 1:100,000-scale digitial data, 1979-1984.
Universal Transverse Mercator Projection, zone 11, NAD83.

\section{EXPLANATION}

Condor Canyon Formation, thickness in meters

Contoured from thickness data in Williams (1967)

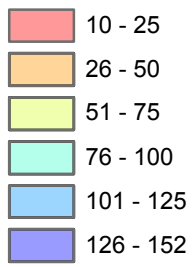

ताTा Caldera boundary

Caldera boundaries modified from Williams and others (1997).,

Roads

----- County boundary

$$
\begin{aligned}
& \begin{array}{lllllll}
0 & 5 & 10 & 20 & 30 & 40 & 50 \\
& & & \text { MILES }
\end{array}
\end{aligned}
$$

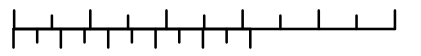

$$
\begin{aligned}
& 051020304050 \text { KILOMETERS }
\end{aligned}
$$

Thickness of Condor Canyon Formation, in meters, contoured at intervals consistent with those used for the thickest tuffs

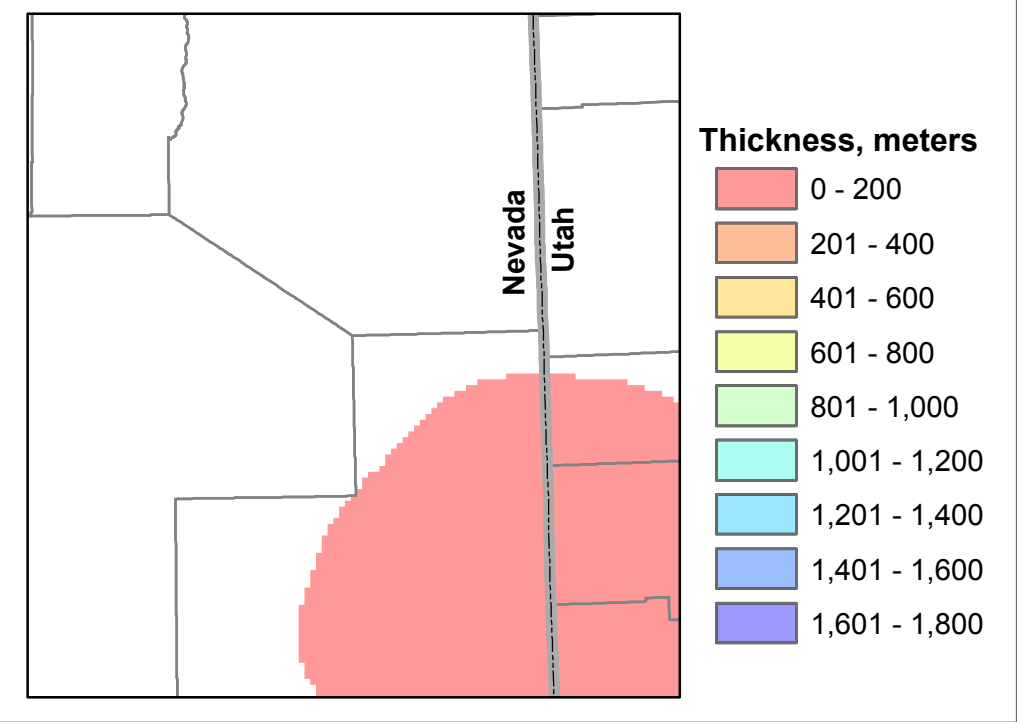

Figure 14. Thickness (isopach) map of Condor Canyon Formation. 


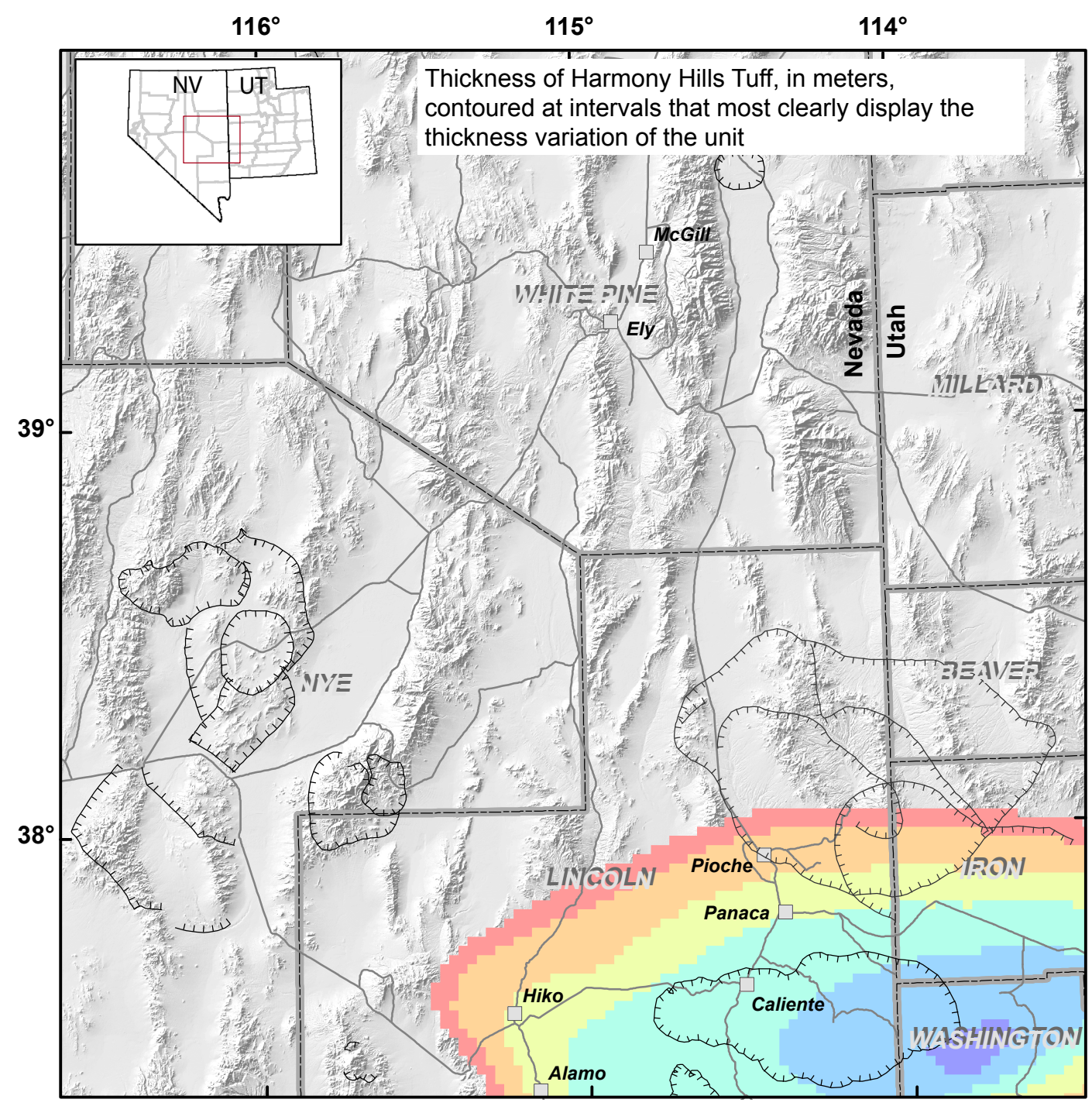

Base from USGS 1:100,000-scale digital data, 1979-1984.
Universal Transverse Mercator Projection, zone 11, NAD83.

\section{EXPLANATION}

Harmony Hills Tuff, thickness in meters

Contoured from thickness data in Williams (1967)

\begin{tabular}{|c|c|}
\hline $10-25$ & ताा Caldera boundary \\
\hline $26-50$ & \multirow{2}{*}{$\begin{array}{l}\text { Caldera boundaries modified from Williams and others (1997), } \\
\text { Loucks and others (1989), Raines and others (1996), Workman an } \\
\text { others (2002), and Gans and others (1989) }\end{array}$} \\
\hline $51-75$ & \\
\hline $76-100$ & —oads \\
\hline $101-125$ & ----- County boundary \\
\hline $126-152$ & \\
\hline & 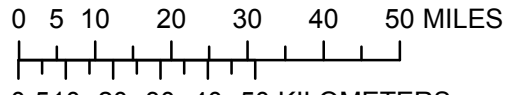 \\
\hline
\end{tabular}

Thickness of Harmony Hills Tuff, in meters, contoured at intervals consistent with those used for the thickest tuffs

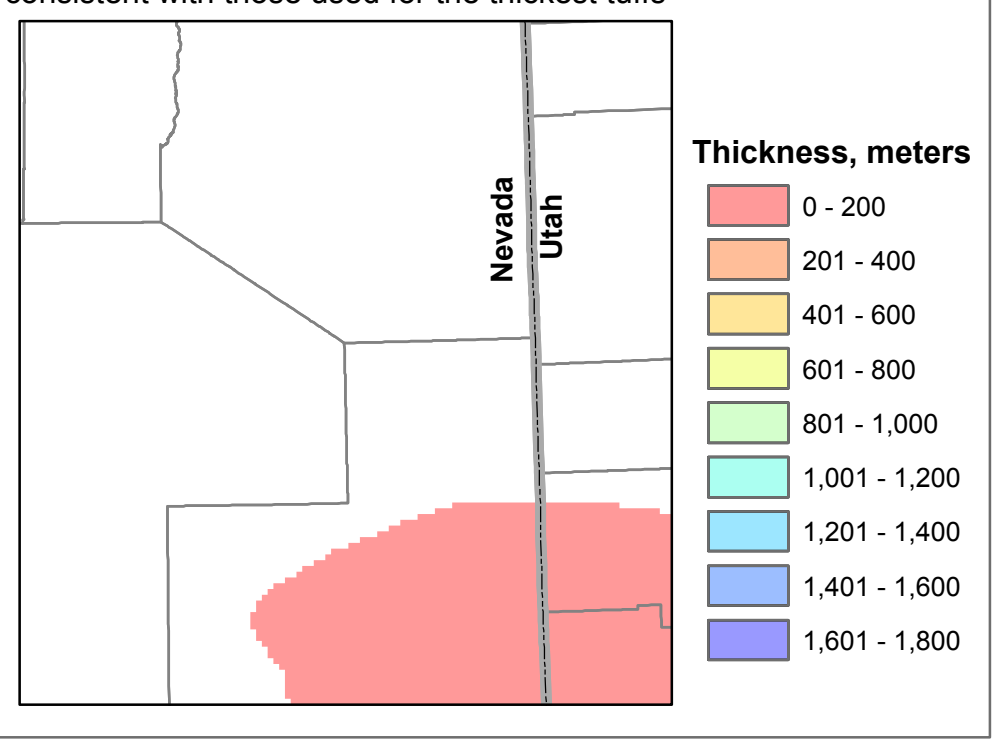

Figure 15. Thickness (isopach) map of Harmony Hills Tuff. 


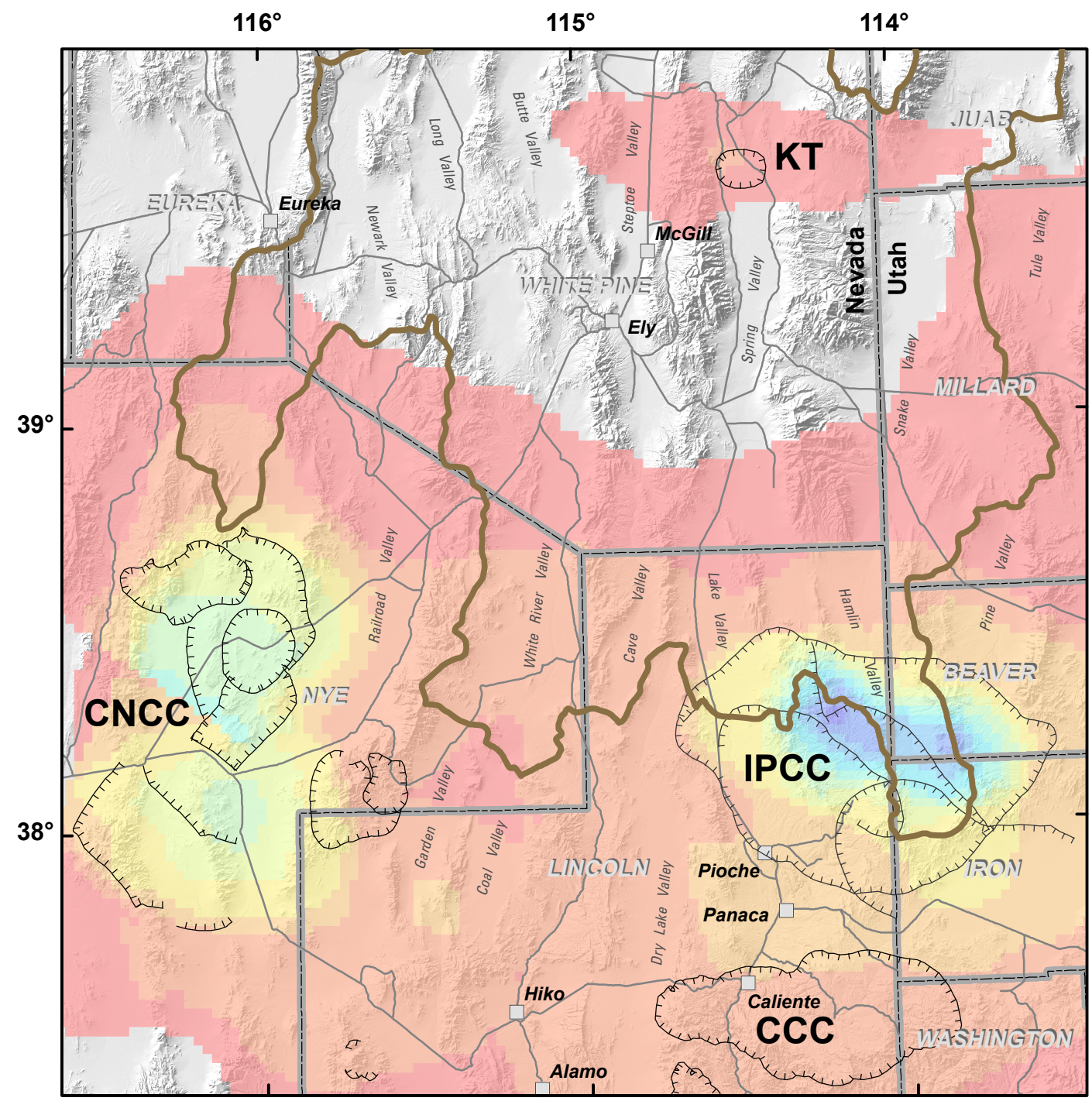

Base from USGS 1:100,000-scale digital data, 1979-1984.
Universal Transverse Mercator Projection, 20ne 11, NAD83.

\section{EXPLANATION}

Combined thickness of all ash-flow tuffs, in meters

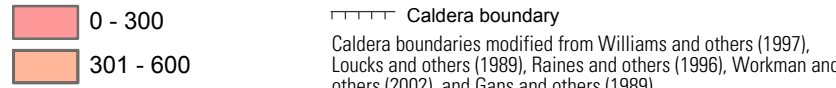

$601-900$

$901-1,200$

$1,201-1,500$

$1,501-1,800$

$1,801-2,100$

$2,101-2,400$

$2,401-2,700$

$2,701-3,000$

$3,001-3,300$ (2002), and Gans and others $(1989)$

CCC, Caliente caldera complex; CNCC, central Nevada caldera complex; IPCC, Indian Peak caldera complex; KT, inferred

- Roads

BARCAS study area boundary

----- County boundary

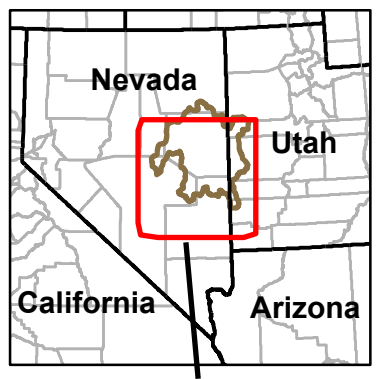

Area shown in figure

$\begin{array}{lllllll}0 & 5 & 10 & 20 & 30 & 40 & 50 \text { Miles }\end{array}$

$|1,1,1|,,||,,|1|$

051020304050 Kilometers

Figure 16. Aggregate thickness (isopach) map of all tuffs for caldera-related Tertiary volcanic rocks in east-central Nevada and west-central Utah. 


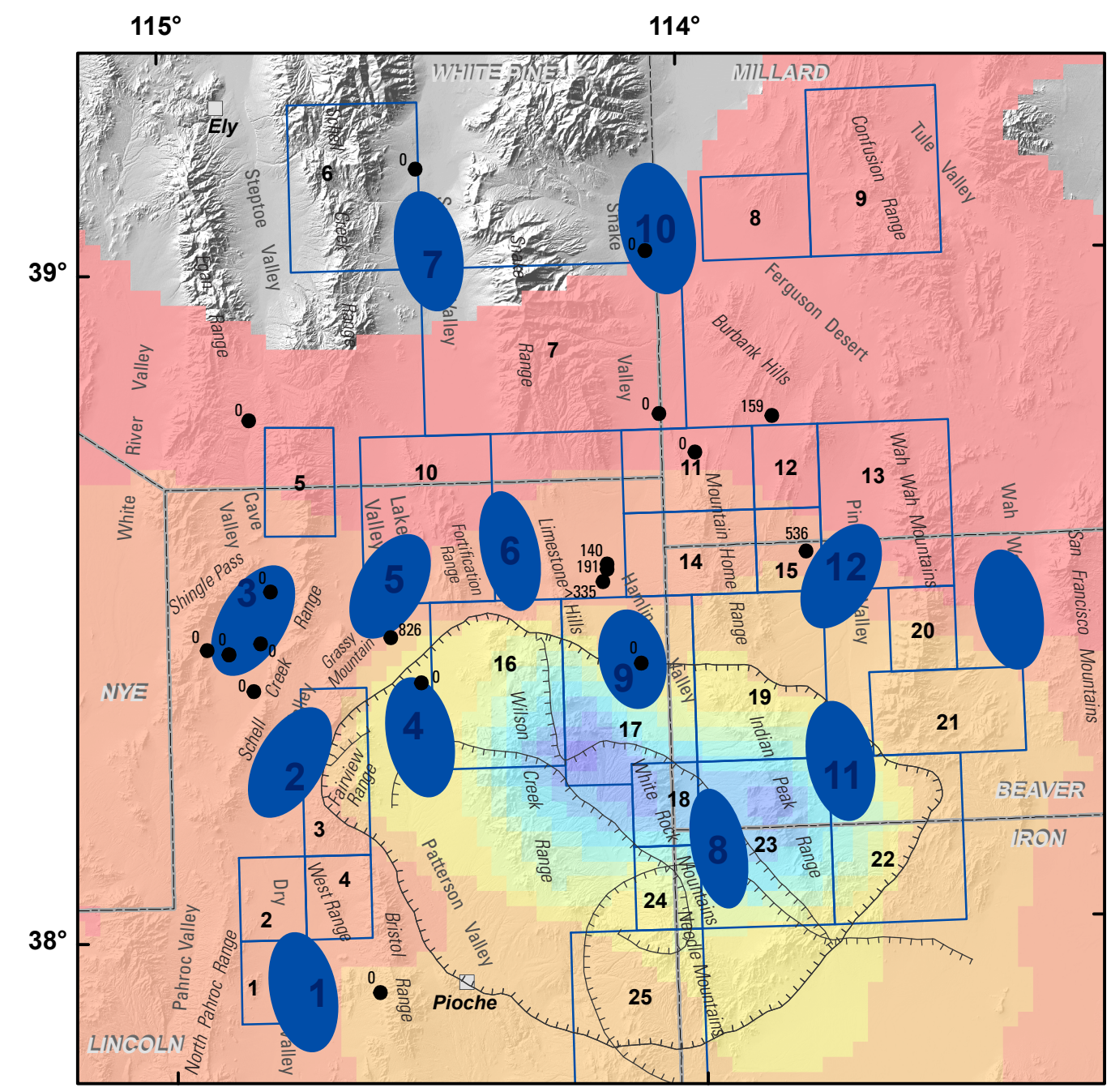

\section{EXPLANATION}

Combined thickness of all ash-flow tuffs, in meters

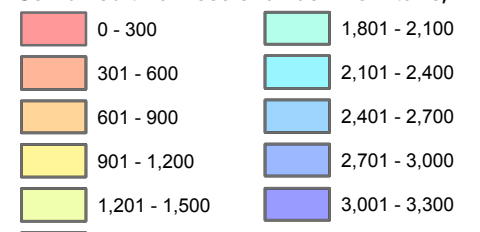

$1,501-1,800$

ताIT Caldera boundary

. Loucks and others (1989), Raines and others (1996), Workman and

----- County boundary

General location of valley axis described in tables $1-13$; table number indicated

230

Oil and gas exploration well; number is thickness of ash-flow tuff penetrated in meters Nevada well data from Hess and others (2004); Utah well data

\section{\begin{tabular}{llllll}
0 & 5 & 10 & 15 & 20 & 25 \\
\hline & 1 & MILES
\end{tabular}}

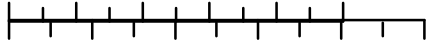

$\begin{array}{lll}0 & 5 & 10\end{array}$

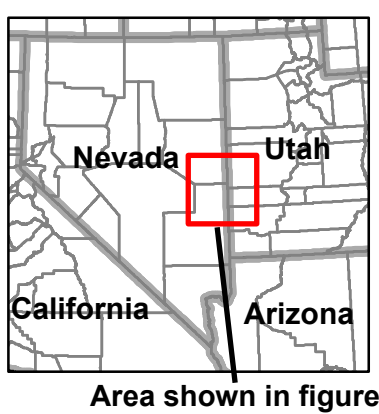

Maps used for thickness compilation

Map

reference Author

number

Swadley and others, 1994

Ekren and Page, 1995

Best and others, 1998

Page and Ekren, 1995

Van Loenen, 1987

Drewes, 1967

Whitebread, 1969

Hose, 1965

Hintze, 1974a

Loucks and others, 1989

Hintze, 1986

Hintze, 1981

Hintze, 1974b

Hintze and Best, 1987

Best and Hintze, 1980

Willis and others, 1987

Best, Toth, and others, 1989

Toth, 1986

Best, Hintze, and Homes, 1987

Wheeler, 1980

Abbott and others, 1983

Best, Morris, and others, 1987

Best, Grant, and others, 1987

Keith and others, 1994

Williams and others, 1997

Base from USGS 1:100,000-scale digital data, 1979-1984.
Universal Transverse Mercator Projection, zone 11, NAD83.

Figure 17. Volcanic thickness (isopach) map showing location of valley axes in eastern Nevada and western Utah described in tables 1-13. 


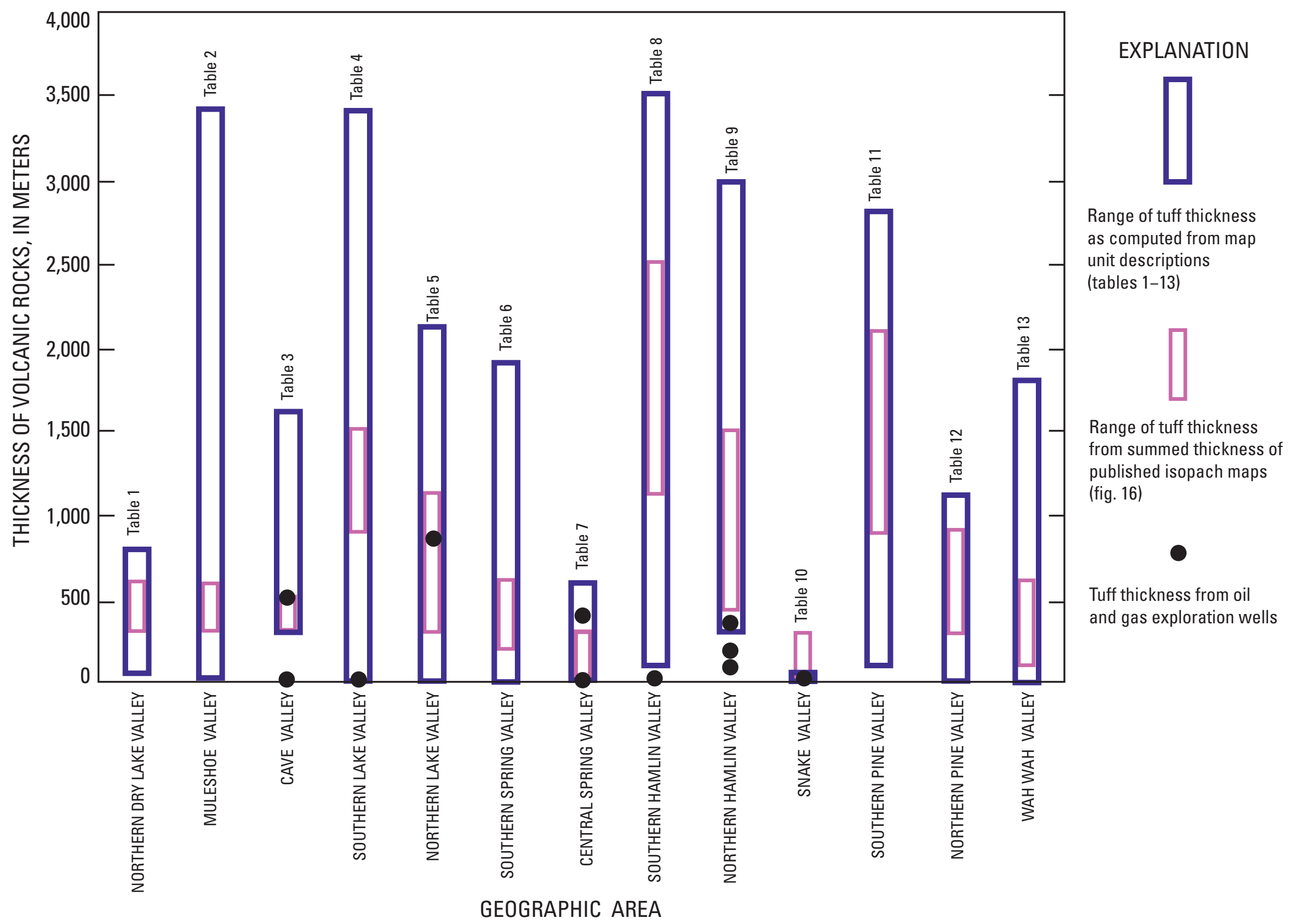

Figure 18. Comparison of tuff thickness compilation methods, east-central Nevada and west-central Utah. Associated table is listed at top of bar. 
Table 1. Compilation of volcanic-rock thickness from mountain ranges flanking the northern part of Dry Lake Valley

[Thickness data for North Pahroc Range from Swadley and others (1994) and Ekren and Page (1995); thickness data for the West Range from Page and Ekren (1995); leaders (--), unit not present]

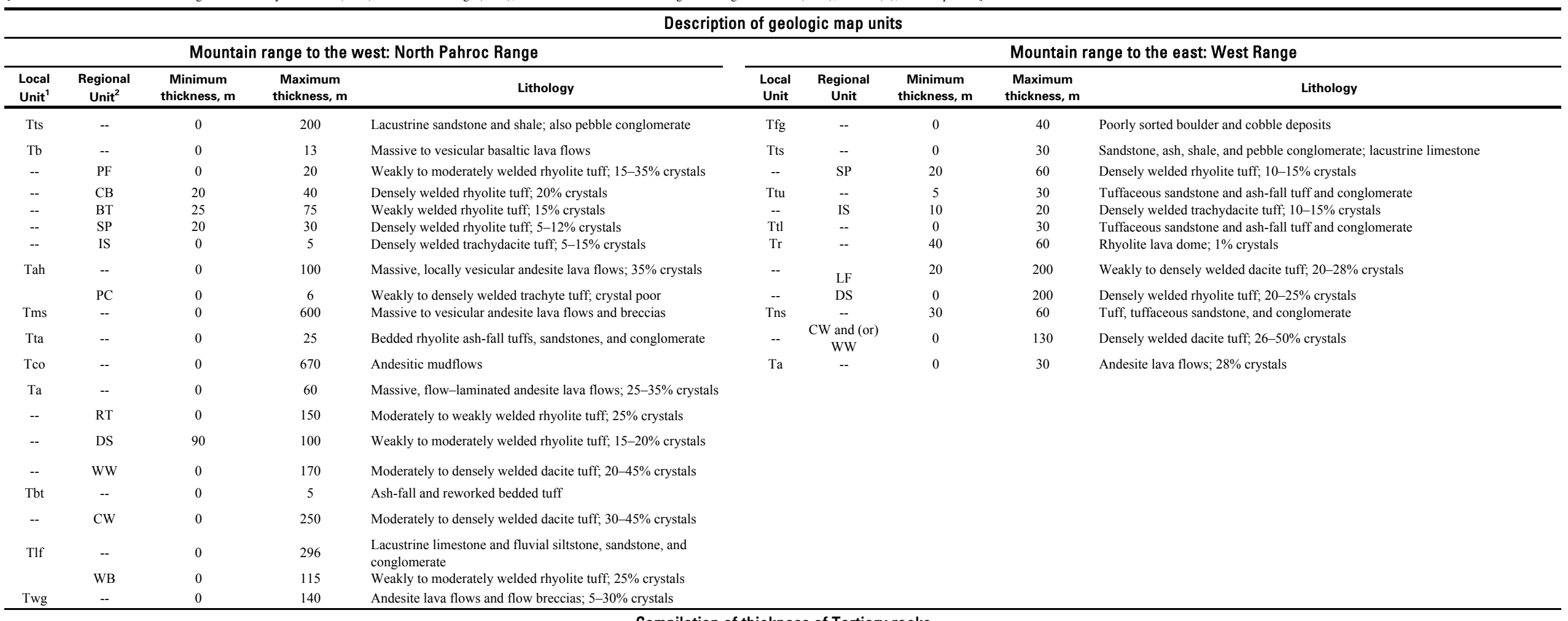

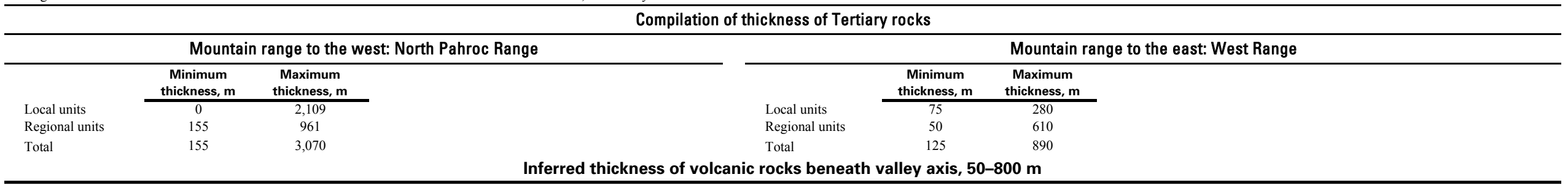

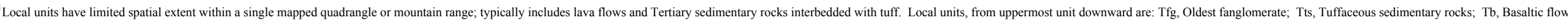

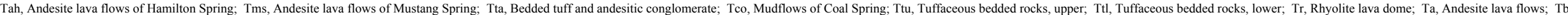
Bedded tuff; Tlf, Lacustrine and fluvial sedimentary rocks; Tns, Sedimentary rocks above Wah Wah Springs Formation; Twg, Andesite lava flows of Wheatgrass Spring

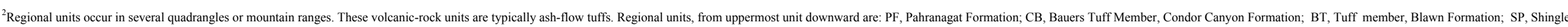
Pass Tuff: IS, Isom Formation; PC, Petroglyph Cliff Ignimbrite; LF, Lund Formation; RT, Rhyolitic tuff: DS, Tuff of Deadman Summit; WW, Wah Wah Springs Formation; CW, Cottonwood Wash Tuff; WB, Windous Butte Formation. 
Table 2. Compilation of volcanic-rock thickness from mountain ranges flanking Muleshoe Valley

[There is no published reference for Tertiary stratigraphic thickness for the Schell Creek Range; thickness data for the Grassy Mountain/Fairview Range area from Best and others (1998); leaders (--), unit not present]

\begin{tabular}{|c|c|c|c|c|c|c|c|c|}
\hline \multicolumn{9}{|c|}{ Description of geologic map units } \\
\hline \multicolumn{4}{|c|}{ Mountain range to the west: the southern part of the Schell Creek Range } & \multicolumn{5}{|c|}{ Mountain range to the east: the Grassy Mountain/Fairview Range area } \\
\hline $\begin{array}{l}\text { Local } \\
\text { Unit }^{1}\end{array}$ & $\begin{array}{c}\text { Regional } \\
\text { Unit }^{2} \\
\end{array}$ & $\begin{array}{c}\text { Minimum } \\
\text { thickness, } m\end{array}$ & $\begin{array}{c}\text { Maximum } \\
\text { thickness, } m\end{array}$ & $\begin{array}{c}\text { Local } \\
\text { Unit }\end{array}$ & $\begin{array}{c}\text { Regional } \\
\text { Unit }\end{array}$ & $\begin{array}{c}\text { Minimum } \\
\text { thickness, } m\end{array}$ & $\begin{array}{c}\text { Maximum } \\
\text { thickness, } m\end{array}$ & Lithology \\
\hline \multirow{23}{*}{\multicolumn{4}{|c|}{$\begin{array}{l}\text { The southern part of the Schell Creek Range, at the head of of Muleshoe Valley, includes a significant outcrop area of } \\
\text { undocumented Tertiary volcanic rock on its east flank. However, further south in the Schell Creek Range, volcanic rocks } \\
\text { are absent. The Grassy Mountain/Fairview Range area, on the east side of Muleshoe Valley, contains a considerable } \\
\text { thickness of Tertiary volcanic rocks. Therefore, assuming that volcanic rock distribution was symmetric around } \\
\text { Muleshoe Valley, thickness relations in the Grassy Mountain/Fairview Range area are used as a proxy for Tertiary } \\
\text { volcanic rock thickness in Muleshoe Valley }\end{array}$}} & Ts & -- & 0 & 80 & Sandstone and conglomeratic sandstone; also limestone and ash-fall tuff \\
\hline & & & & $\mathrm{Tbm}$ & -- & 0 & 60 & Somewhat porphyritic, aphanitic mafic lava flows \\
\hline & & & & -- & BT & 0 & 10 & Weakly consolidated rhyolite tuff; $2-4 \%$ crystals \\
\hline & & & & -- & $\mathrm{PF}$ & 0 & 230 & Moderately welded rhyolite tuff; $15-35 \%$ crystals \\
\hline & & & & -- & $\mathrm{CB}$ & 0 & 40 & Densely welded rhyolite tuff; $3-5 \%$ crystals \\
\hline & & & & $\operatorname{Tr}$ & -- & 0 & 200 & Aphyric rhyolite lava flows \\
\hline & & & & -- & LC & 0 & 75 & Partly welded rhyolite tuff; $20 \%$ crystals \\
\hline & & & & -- & IS & 10 & 20 & Densely welded trachydacite tuff; $20 \%$ crystals \\
\hline & & & & -- & SPU & 0 & 200 & Moderately to densely welded rhyolite tuff; $15 \%$ crystals \\
\hline & & & & -- & SPL & 0 & 200 & Moderately to densely welded rhyolite tuff; $15 \%$ crystals \\
\hline & & & & -- & RAT & 0 & 60 & Moderately welded rhyolite tuff; $10 \%$ crystals \\
\hline & & & & Tch & -- & 0 & 100 & Flow-layered dacite lava flow; $15 \%$ crystals \\
\hline & & & & -- & RT & 0 & 60 & Weakly welded rhyolite tuff; $5 \%$ crystals \\
\hline & & & & -- & $\mathrm{PC}$ & 0 & 70 & Densely to moderately welded trachydacite tuff; $10 \%$ crystals \\
\hline & & & & -- & LF & 0 & 1,000 & Moderately to densely welded dacite tuff; $55 \%$ crystals \\
\hline & & & & -- & SK & 0 & 600 & Moderately to densely welded dacite tuff; $33 \%$ crystals \\
\hline & & & & -- & RST & 0 & 30 & Rhyolite tuff; $15 \%$ crystals \\
\hline & & & & -- & DS & 0 & 380 & Densely welded rhyolite tuff; $33 \%$ crystals \\
\hline & & & & -- & WB & 0 & 3 & Partly welded rhyolite tuff \\
\hline & & & & $\mathrm{Ta}$ & -- & 0 & 300 & Altered, aphanitic andesite lava flows; abundant phenocrysts \\
\hline & & & & $\mathrm{Tb}$ & -- & 0 & 30 & Massive, altered, aphanitic rhyolite lava flows; $15 \%$ phenocrysts \\
\hline & & & & -- & SW & 0 & 40 & Moderately to weakly welded tuff; $40 \%$ crystals \\
\hline & & & & Tls & -- & 0 & 20 & Thinly bedded lacustrine limestone \\
\hline
\end{tabular}

Compilation of thickness of Tertiary rocks

\begin{tabular}{|c|c|c|c|c|c|}
\hline \multicolumn{3}{|c|}{ Mountain range to the west: the southern part of the Schell Creek Range } & \multicolumn{3}{|c|}{ Mountain range to the east: the Grassy Mountain/Fairview Range area } \\
\hline & $\begin{array}{c}\text { Minimum } \\
\text { thickness, } m\end{array}$ & $\begin{array}{c}\text { Maximum } \\
\text { thickness, } m\end{array}$ & & $\begin{array}{c}\text { Minimum } \\
\text { thickness, } m\end{array}$ & $\begin{array}{c}\text { Maximum } \\
\text { thickness, } m\end{array}$ \\
\hline Local units & 0 & 46 & Local units & 0 & 690 \\
\hline Regional units & 144 & 1,113 & Regional units & 22 & 3,418 \\
\hline Total & 144 & 1,159 & Total & 22 & 4,108 \\
\hline \multicolumn{6}{|c|}{ Inferred thickness of volcanic rocks beneath valley axis, $23-3,400 \mathrm{~m}$} \\
\hline
\end{tabular}

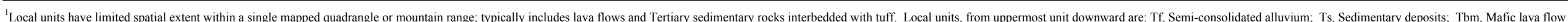
member, Blawn Formation; Tr, Rhyolite lava flows; Tch, Lava flow of Chokecherry Spring; Ta, Andesitic lava flows; Tb, Rhyolite lava flow of Bailey Spring; Tls, Limestone.

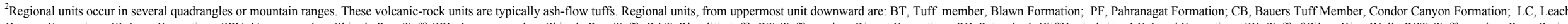

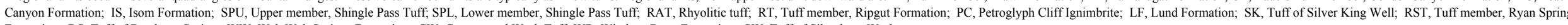
Formation; DS, Tuff of Deadman Spring; WW, Wah Wah Springs Formation; CW, Cottonwood Wash Tuff; WB, Windous Butte Formation; SW, Tuff of Silverhorn Was 
Table 3. Compilation of volcanic-rock thickness from mountain ranges flanking Cave Valley

[Thickness data for the Egan Range (near Shingle Pass) from Kellogg (1964), Best and Christiansen (1996), and Best, Christiansen, and others (1989); no published reference for Tertiary stratigraphic thickness for the Schell Creek Range; leaders (--), unit

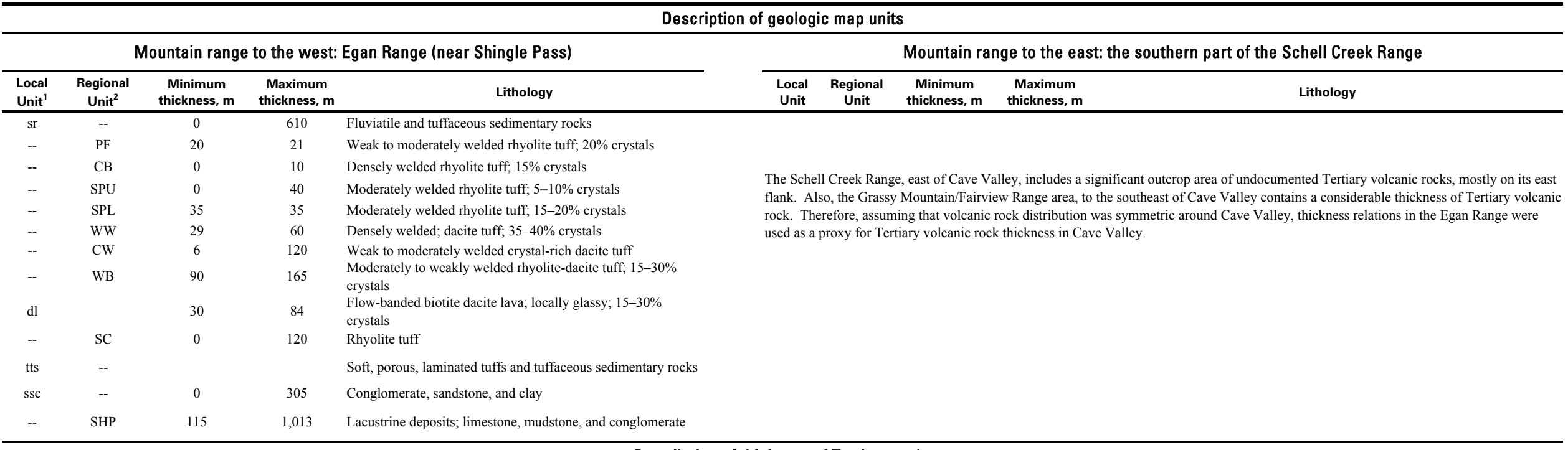

\begin{tabular}{|c|c|c|c|c|c|}
\hline \multicolumn{6}{|c|}{ Compilation of thickness of Tertiary rocks } \\
\hline & \multicolumn{3}{|c|}{ Mountain range to the west: Egan Range (near Shingle Pass) } & \multicolumn{2}{|c|}{ Mountain range to the east: the southern part of the Schell Creek Range } \\
\hline & $\begin{array}{c}\begin{array}{c}\text { Minimum } \\
\text { thickness, } m\end{array} \\
\end{array}$ & $\begin{array}{c}\begin{array}{c}\text { Maximum } \\
\text { thickness, } m\end{array} \\
\end{array}$ & & $\begin{array}{c}\text { Minimum } \\
\text { thickness, } m\end{array}$ & $\begin{array}{c}\text { Maximum } \\
\text { thickness, } m\end{array}$ \\
\hline Local units & 30 & 999 & Local units & -- & -- \\
\hline Regional units & 180 & 1,584 & Regional units & -- & -- \\
\hline Total & 325 & 2,583 & Total & -- & -- \\
\hline \multicolumn{6}{|c|}{ Inferred thickness of volcanic rocks beneath valley axis, $300-1,600 \mathrm{~m}$} \\
\hline
\end{tabular}

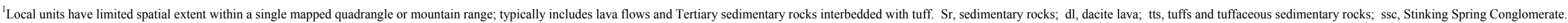

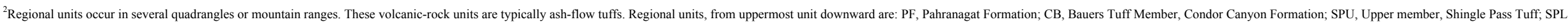
Lower member, Shingle Pass Tuff; WW, Wah Wah Springs Formation; CW, Cottonwood Wash Tuff; WB, Windous Butte Formation; SC, Stone Cabin Formation; SHP, Sheep Pass Formation. 
Table 4. Compilation of volcanic-rock thickness from mountain ranges flanking southern part of Lake Valley

[Thickness data for the Grassy Mountain/Fairview Range area and Bristol Range from Best and others (1998); thickness data for the Wilson Creek Range from Willis and others (1987) and Williams and others (1997); leaders (--), unit not present]

\begin{tabular}{|c|c|c|c|c|c|c|c|c|c|}
\hline \multicolumn{5}{|c|}{ Mountain range to the west: Grassy Mountain/Fairview Range area and Bristol Range ${ }^{1}$} & \multicolumn{5}{|c|}{ Mountain range to the east: Willson Creek Range } \\
\hline $\begin{array}{l}\text { Local } \\
\text { Unit }^{2}\end{array}$ & $\begin{array}{c}\text { Regional } \\
\text { Unit }^{3}\end{array}$ & $\begin{array}{c}\text { Minimum } \\
\text { thickness, } m\end{array}$ & $\begin{array}{c}\text { Maximum } \\
\text { thickness, } m\end{array}$ & Lithology & $\begin{array}{c}\text { Local } \\
\text { Unit }\end{array}$ & $\begin{array}{c}\text { Regional } \\
\text { Unit }\end{array}$ & $\begin{array}{c}\text { Minimum } \\
\text { thickness, } m\end{array}$ & $\begin{array}{c}\text { Maximum } \\
\text { thickness, } m\end{array}$ & Lithology \\
\hline Tf & -- & 0 & 30 & Partly consolidated sandstone, locally conglomeratic; mudflow breccia & Tal & -- & 0 & 50 & Alluvial fan deposits; poorly sorted boulders and cobbles \\
\hline $\mathrm{Tbm}$ & .- & 0 & 60 & Somewhat porphyritic, aphanitic mafic lava flows & $\mathrm{Te}$ & -- & 0 & 110 & Thin bedded, lacustrine silt and sand; some sand, pebbles, and tephra \\
\hline -- & BT & 0 & 10 & Weakly consolidated rhyolite tuff; $2-4 \%$ crystals & Tsr & -- & 0 & 250 & Aphanitic rhyolite lava flows and domes; $10 \%$ crystals \\
\hline -- & $\mathrm{PF}$ & 0 & 230 & Moderately welded rhyolite tuff; $15-35 \%$ crystals & -- & $\mathrm{SR}$ & 0 & 120 & Porous volcaniclastic deposits; some sandstone \\
\hline -- & СВ & 0 & 40 & Densely welded rhyolite tuff; $3-5 \%$ crystals & $\mathrm{Tt}$ & -- & 0 & 140 & Porous pyroclastic and epiclastic deposits \\
\hline $\operatorname{Tr}$ & -- & 0 & 200 & Aphyric rhyolite lava flows & $\mathrm{Tbr}$ & .- & 0 & 230 & Aphanitic rhyolite lava flows and domes; $10-20 \%$ crystals \\
\hline Ts & .- & 0 & 80 & Sandstone and conglomeratic sandstone; also limestone and ash-fall tuff & -- & ВT & 0 & 450 & Partly welded rhyolite tuff and epiclastic deposits \\
\hline-- & $\mathrm{LC}$ & 0 & 75 & Partly welded rhyolite tuff; $20 \%$ crystals & .- & BG & 0 & 80 & Moderately welded tuff; $20 \%$ crystals \\
\hline -- & IS & 10 & 20 & Densely welded trachydacite tuff; $20 \%$ crystals & -- & $\mathrm{RC}$ & 0 & 1,050 & Weakly to densely welded rhyolite tuff; $25-40 \%$ crystals \\
\hline .- & SPU & 0 & 200 & Moderately to densely welded rhyolite tuff; $15 \%$ crystals & Ts & -- & 0 & 600 & Fluvial-lacustrine conglomerate, sandstone, siltstone, and limestone \\
\hline .- & SPL & 0 & 200 & Moderately to densely welded rhyolite tuff; $15 \%$ crystals & Tscl & -- & 0 & 300 & Dacite and rhyolite lava flows and minor tuff; $25 \%$ crystals \\
\hline -- & RAT & 0 & 60 & Moderately welded rhyolite tuff; $10 \%$ crystals & $\mathrm{Tn}$ & .- & 150 & 250 & Dacite to andesite lava flows; $20 \%$ crystals; locally vesicular \\
\hline Tch & -- & 0 & 100 & Flow-layered dacite lava flow; $15 \%$ crystals & -- & нн & 20 & 150 & Densely to moderately welded andesite tuff; $50 \%$ crystals \\
\hline-- & $\mathrm{RF}$ & 0 & 60 & Weakly welded rhyolite tuff; $5 \%$ crystals & Tf & -- & 0 & 100 & Rhyolite lava flows \\
\hline .- & $\mathrm{PC}$ & 0 & 70 & Densely to moderately welded trachydacite tuff; $10 \%$ crystals & Tlf & -- & 0 & 1,000 & Trachyandesite to trachydacite flows; $5-25 \%$ crystals \\
\hline .- & LF & 0 & 1,000 & Moderately to densely welded dacite tuff; $55 \%$ crystals & -- & AFT & 0 & 150 & Densely welded tuff; $25 \%$ crystals \\
\hline -- & SK & 0 & 600 & Moderately to densely welded dacite tuff; $33 \%$ crystals & $\mathrm{Tl}$ & -- & 0 & 130 & Flow-layered lava flow \\
\hline -- & RST & 0 & 30 & Rhyolite tuff; $15 \%$ crystals & -- & $\mathrm{CB}$ & 10 & 200 & Densely welded rhyolite tuff; $3-5 \%$ crystals \\
\hline -- & DS & 0 & 380 & Densely welded rhyolite tuff; $33 \%$ crystals & .- & CS & 0 & 200 & Densely welded rhyolite tuff; $3-5 \%$ crystals \\
\hline .- & wW & 0 & 120 & Densely welded dacite tuff; $40 \%$ crystals & $\operatorname{Teg}$ & -- & 0 & 50 & Poorly-sorted boulder and cobble conglomerate \\
\hline -- & $\mathrm{CW}$ & 12 & 280 & Densely to moderately welded dacite tuff; crystal rich & -- & LC & 200 & 400 & Partly welded rhyolite tuff; $20 \%$ crystals \\
\hline -- & WB & 0 & 3 & Partly welded rhyolite tuff & -- & IS & 0 & 200 & Moderately to densely welded trachydacite; $20 \%$ crystals \\
\hline $\mathrm{Ta}$ & -- & 0 & 300 & Altered, aphanitic andesite lava flows; abundant phenocrysts & .- & $\mathrm{RF}$ & 200 & 650 & Partly to densely welded rhyolite tuff; crystal poor \\
\hline $\mathrm{Tb}$ & -- & 0 & 30 & Massive, altered, aphanitic rhyolite lava flows; $15 \%$ phenocrysts & -- & LF & 0 & 150 & Moderately to densely welded dacite tuff; $30-40 \%$ crystals \\
\hline-- & sw & 0 & 40 & Moderately to weakly welded tuff; $40 \%$ crystals & -- & ww & 0 & 50 & Densely welded dacite tuff; $40 \%$ crystals \\
\hline \multicolumn{10}{|c|}{ Compilation of thickness of Tertiary rocks } \\
\hline \multicolumn{5}{|c|}{ Mountain range to the west: Grassy Mountain/Fairview Range area and Bristol Range } & \multicolumn{5}{|c|}{ Mountain range to the east: Wilson Creek Range } \\
\hline \multirow{4}{*}{\multicolumn{2}{|c|}{$\begin{array}{l}\text { Local units } \\
\text { Regional units } \\
\text { Total }\end{array}$}} & $\begin{array}{c}\text { Minimum } \\
\text { thickness, } m\end{array}$ & $\begin{array}{c}\text { Maximum } \\
\text { thickness, } m\end{array}$ & & \multirow{3}{*}{\multicolumn{2}{|c|}{$\begin{array}{l}\text { Local units } \\
\text { Regional units }\end{array}$}} & $\begin{array}{c}\text { Minimum } \\
\text { thickness, } m\end{array}$ & $\begin{array}{l}\text { Maximum } \\
\text { thickness, } m\end{array}$ & \\
\hline & & 0 & 800 & & & & 150 & $\frac{3,210}{3,10}$ & \\
\hline & & 22 & 3,418 & & & & 430 & 3,850 & \\
\hline & & 22 & 4,218 & & Total & & 580 & 7,060 & \\
\hline
\end{tabular}

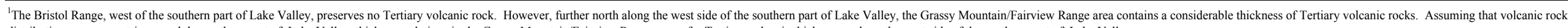
distribution was symmetric around the southern part of Lake Valley, thickness relations in the Grassy Mountain/Fairview Range proxy for Tertiary volcanic thicknesses along the west side of the southern part of Lake Valley.

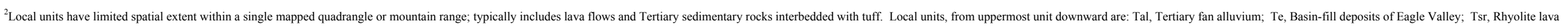

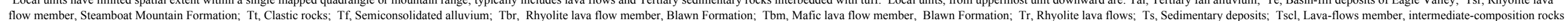
of Serviceberry Canyon; Tn, Lava flows of Ninemile Rocks; Tch, Lava flow of Chokecherry Spring; Tf, Rhyolite lava flow of Tobe Spring; Tlf, Latite lava flows; Tl, Lava flow; Teg, Conglomerate; Ta, Andesitic lava flows; Tb, Rhyolite lava flow of Bailey Spring.

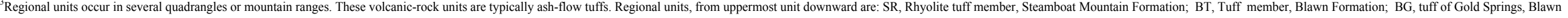

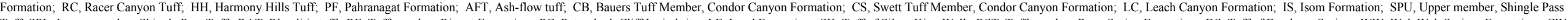

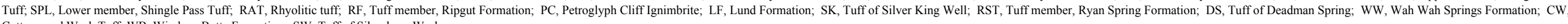
Cottonwood Wash Tuff; WB, Windous Butte Formation; SW, Tuff of Silverhorn Wash. 
Table 5. Compilation of volcanic-rock thickness from mountain ranges flanking northern part of Lake Valley

[Thickness data for the central part of the Schell Creek Range from Van Loenen (1987); thickness data for the Fortification Range from Loucks and others (1989); leaders (--), unit not present]

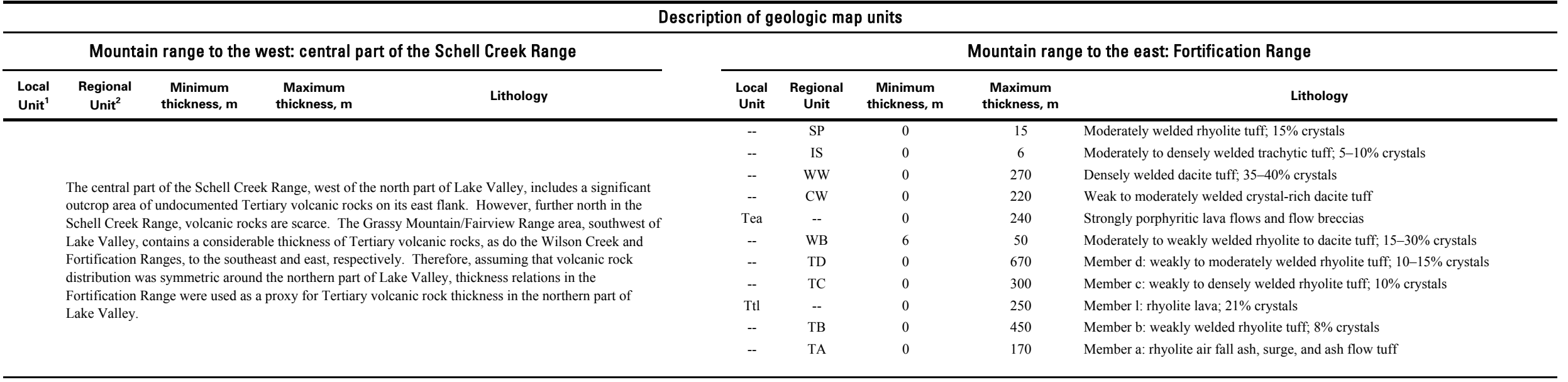

\section{Compilation of thickness of Tertiary rocks}

\begin{tabular}{|c|c|c|c|c|c|}
\hline \multicolumn{3}{|c|}{ Mountain range to the west: central part of the Schell Creek Range } & \multicolumn{3}{|c|}{ Mountain range to the east: Fortification Range } \\
\hline & $\begin{array}{c}\text { Minimum } \\
\text { thickness, } m\end{array}$ & $\begin{array}{c}\text { Maximum } \\
\text { thickness, } m\end{array}$ & & $\begin{array}{c}\text { Minimum } \\
\text { thickness, } m\end{array}$ & $\begin{array}{c}\text { Maximum } \\
\text { thickness, } m\end{array}$ \\
\hline Local units & -- & -- & Local units & 0 & 490 \\
\hline Regional units & -- & -- & Regional units & 6 & 2,151 \\
\hline Total & -- & -- & Total & 6 & 2,641 \\
\hline \multicolumn{6}{|c|}{ Inferred thickness of volcanic rocks beneath valley axis, 6-2,100 m } \\
\hline
\end{tabular}

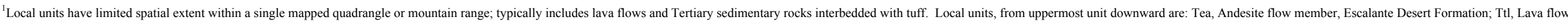
member, formation of the Gouge Eye.

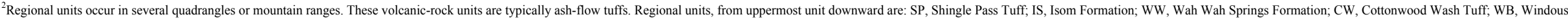
Butte Formation; TD, Member d, formation of the Gouge Eye; TC, Member c, formation of the Gouge Eye; TB, Member b, formation of the Gouge Eye; TA, Member a, formation of the Gouge Eye. 
Table 6. Compilation of volcanic-rock thickness from mountain ranges flanking southern part of Spring Valley [Thickness data for the Fortification Range from Loucks and others (1989); thickness data for the Wilson Creek Range and Limestone Hills from Willis and others (1987); leaders (--), unit not present]

Description of geologic map units

\begin{tabular}{|c|c|c|c|c|c|c|c|c|c|}
\hline \multicolumn{5}{|c|}{ Mountain range to the west: Fortification Range } & \multicolumn{5}{|c|}{ Mountain range to the east: Wilson Creek Range and Limestone Hills ${ }^{3}$} \\
\hline $\begin{array}{l}\text { Local } \\
\text { Unit }\end{array}$ & $\begin{array}{l}\text { Regional } \\
\text { Unit }^{2}\end{array}$ & $\begin{array}{c}\text { Minimum } \\
\text { thickness, } m\end{array}$ & $\begin{array}{c}\text { Maximum } \\
\text { thickness, } m\end{array}$ & Lithology & $\begin{array}{l}\text { Local } \\
\text { Unit }\end{array}$ & $\begin{array}{c}\text { Regional } \\
\text { Unit }\end{array}$ & $\begin{array}{c}\text { Minimum } \\
\text { thickness, } m\end{array}$ & $\begin{array}{c}\text { Maximum } \\
\text { thickness, } m\end{array}$ & Lithology \\
\hline-- & SP & 0 & 15 & Moderately welded rhyolite tuff; $15 \%$ crystals & Tbr & -- & 0 & 200 & Rhyolite lava flows and domes; $10-15 \%$ crystals; local vitrophyre \\
\hline -- & IS & 0 & 6 & Moderately to densely welded trachytic tuff; $5-10 \%$ crystals & -- & BT & 0 & 200 & Weakly to moderately welded rhyolite tuff, ash, and clastics; $10 \%$ crystals \\
\hline -- & WW & 0 & 270 & Densely welded dacite tuff; $35-40 \%$ crystals & $\mathrm{Tba}$ & & 0 & 135 & Vesicular, aphyric to strongly porphyritic trachyandesite lava flows \\
\hline -- & $\mathrm{CW}$ & 0 & 220 & Weak to moderately welded crystal-rich dacite tuff & -- & BP & 0 & 200 & Moderately to weakly welded rhyolite tuff; $25-30 \%$ crystals \\
\hline Tea & -- & 0 & 240 & Strongly porphyritic lava flows and flow breccias & -- & SP & 0 & 100 & Moderately to densely welded rhyolite tuff; $20 \%$ crystals \\
\hline-- & wB & 6 & 50 & Moderately to weakly welded rhyolite to dacite tuff; $15-30 \%$ & -- & IS & 0 & 300 & Densely welded trachytic tuff; $10-12 \%$ crystals \\
\hline-- & TD & 0 & 670 & Member d: weakly to moderately welded rhyolite tuff; $10-15 \%$ & -- & $\mathrm{RF}$ & 0 & 200 & Moderately to densely welded rhyolite tuff; $\sim 3 \%$ crystals \\
\hline $\mathrm{Ttl}$ & -- & 0 & 250 & Member 1: rhyolite lava; $21 \%$ crystals & -- & RM & 0 & 100 & Densely welded rhyolite tuff; $10-15 \%$ crystals \\
\hline -- & TB & 0 & 450 & Member b: weakly welded rhyolite flow tuff; $8 \%$ crystals & -- & RG & 0 & 200 & Moderately welded rhyolite tuff; crystal poor \\
\hline \multirow[t]{4}{*}{--} & TA & 0 & 170 & Member a: rhyolite air fall ash, surge, and ash flow tuff & -- & WW & 0 & 270 & Densely welded dacite tuff; $40 \%$ crystals \\
\hline & & & & & -- & $\mathrm{CW}$ & 0 & 200 & Dacite tuff; $40 \%$ crystals \\
\hline & & & & & Tea & -- & 0 & 200 & Weakly porphyritic lava flows and flow breccias \\
\hline & & & & & -- & WB & 0 & 100 & Moderately to weakly welded rhyolite tuff; $25 \%$ crystals \\
\hline
\end{tabular}

Compilation of thickness of Tertiary rocks

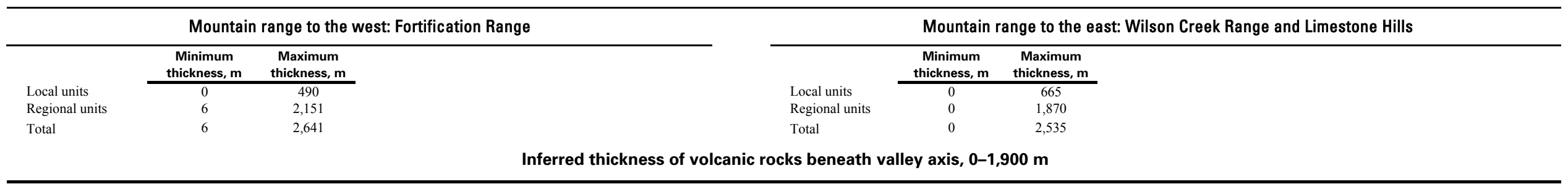

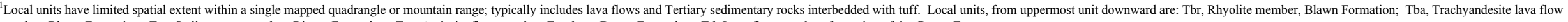
member, Blawn Formation; Tgs, Sedimentary member, Ripgut Formation; Tea, Andesite flow member, Escalante Desert Formation; Ttl, Lava flow member, formation of the Gouge Eye.

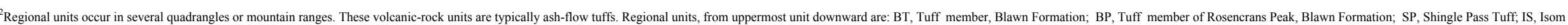

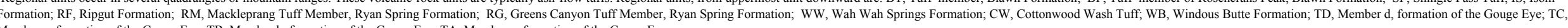
Member c, formation of the Gouge Eye; TB, Member b, formation of the Gouge Eye; TA, Member a, formation of the Gouge Eyc.

${ }^{3}$ The Limestone Hills, directly east of the southern part of Spring Valley, are essentially devoid of Tertiary volcanic rocks; not factored into valley volcanic thickness estimates. 
Table 7. Compilation of volcanic-rock thickness from mountain ranges flanking the central part of Spring Valley

[Thickness data for the northern part of Schell Creek Range from Drewes (1967); for the Snake Range from Whitebread (1969); leaders (--), unit not present]

\begin{tabular}{|c|c|c|c|c|c|c|c|c|c|}
\hline \multicolumn{10}{|c|}{ Description of geologic map units } \\
\hline \multicolumn{5}{|c|}{ Mountain range to the west: northern part of Schell Creek Range } & \multicolumn{5}{|c|}{ Mountain range to the east: Snake Range } \\
\hline $\begin{array}{l}\text { Local } \\
\text { Unit }^{1} \\
\end{array}$ & $\begin{array}{c}\text { Regional } \\
\text { Unit }^{2}\end{array}$ & $\begin{array}{c}\text { Minimum } \\
\text { thickness, } \mathrm{m}\end{array}$ & $\begin{array}{c}\text { Maximum } \\
\text { thickness, } m\end{array}$ & Lithology & $\begin{array}{c}\text { Local } \\
\text { Unit }\end{array}$ & $\begin{array}{c}\text { Regional } \\
\text { Unit }\end{array}$ & $\begin{array}{c}\text { Minimum } \\
\text { thickness, } m\end{array}$ & $\begin{array}{c}\text { Maximum } \\
\text { thickness, } m\end{array}$ & Lithology \\
\hline $\mathrm{Td}$ & -- & 0 & 365 & Dacite lava; vitrophyre in part; $15-50 \%$ crystals & & & & & \\
\hline-- & $\begin{array}{c}\text { WW and (or) } \\
\mathrm{CW}\end{array}$ & 0 & 610 & Dacite tuff; vitrophyre in part & \multicolumn{5}{|c|}{ Southern part of the Snake Range: } \\
\hline $\mathrm{Tl}$ & -- & 0 & 100 & Latite; includes lava flows, tuff, and small intrusions & $\mathrm{Tc}$ & -- & -- & -- & Conglomerate \\
\hline $\mathrm{Tc}$ & & & & & Tco & -- & -- & -- & Conglomerate \\
\hline \multicolumn{10}{|c|}{ Compilation of thickness of Tertiary rocks } \\
\hline \multicolumn{5}{|c|}{ Mountain range to the west: northern part of Schell Creek Range } & \multicolumn{5}{|c|}{ Mountain range to the east: Snake Range } \\
\hline \multirow{3}{*}{\multicolumn{2}{|c|}{$\begin{array}{l}\text { Local units } \\
\text { Regional units } \\
\text { Total }\end{array}$}} & $\begin{array}{c}\text { Minimum } \\
\text { thickness, } m\end{array}$ & $\begin{array}{c}\text { Maximum } \\
\text { thickness, } m\end{array}$ & & \multirow{2}{*}{\multicolumn{2}{|c|}{ Local units }} & $\begin{array}{c}\text { Minimum } \\
\text { thickness, } m\end{array}$ & $\begin{array}{c}\text { Maximum } \\
\text { thickness, } m\end{array}$ & \\
\hline & & $\overline{0}$ & 861 & & & & $\overline{--}$ & -- & \\
\hline & & 0 & 610 & & \multicolumn{2}{|c|}{ Regional units } & 200 & 300 & \\
\hline
\end{tabular}

${ }^{1}$ Local units have limited spatial extent within a single mapped quadrangle or mountain range; typically includes lava flows and Tertiary sedimentary rocks interbedded with tuff. Tf, fanglomerate; Tc, conglomerate; Td, dacite; $\mathrm{Tl}$, latite; and Tco, conglomerate.

${ }^{2}$ Regional units occur in several quadrangles or mountain ranges. These volcanic-rock units are typically ash-flow tuffs. WW, Wah Wah Springs Formation; CW, Cottonwood Wash Tuff. 
Table 8. Compilation of volcanic-rock thickness from mountain ranges flanking southern part of Hamlin Valley

[Thickness data for the southern part of the White Rock Mountains from Toth (1986) and Keith and others (1994); thickness data for the east-central Mountain Home Range from Best, Grant, and others (1987); leaders (--), unit not present]

\begin{tabular}{|c|c|c|c|c|c|c|c|c|c|}
\hline \multicolumn{10}{|c|}{ Description of geologic map units } \\
\hline \multicolumn{5}{|c|}{ Mountain range to the west: the southern part of the White Rock Mountains } & \multicolumn{5}{|c|}{ Mountain range to the east: the southern part of the Indian Peak Range } \\
\hline $\begin{array}{l}\text { Local } \\
\text { Unit }^{1}\end{array}$ & $\begin{array}{l}\text { Regional } \\
\text { Unit }^{2}\end{array}$ & $\begin{array}{c}\text { Minimum } \\
\text { thickness, } \mathrm{m}\end{array}$ & $\begin{array}{c}\text { Maximum } \\
\text { thickness, } m\end{array}$ & Lithology & $\begin{array}{l}\text { Local } \\
\text { Unit }\end{array}$ & $\begin{array}{c}\text { Regional } \\
\text { Unit }\end{array}$ & $\begin{array}{c}\text { Minimum } \\
\text { thickness, } m\end{array}$ & $\begin{array}{c}\text { Maximum } \\
\text { thickness, } \mathrm{m}\end{array}$ & Lithology \\
\hline $\mathrm{Tp}$ & -- & 300 & 400 & Weakly bedded clay and silt deposits & Tsr & -- & 0 & 500 & Aphanitic rhyolite lava flows and domes; $0-30 \%$ crystals \\
\hline Tbr & -- & 0 & 230 & Aphanitic rhyolite lava flows and domes; $10-20 \%$ crystals & Tbr & -- & 0 & 100 & Rhyolite lava flows, domes, and dikes; $25 \%$ crystals \\
\hline-- & BT & 0 & 150 & Weakly welded tuff; crystal poor & Tbm & -- & 0 & 500 & Massive porphyritic mafic lava flows; $10 \%$ crystals \\
\hline-- & BG & 0 & 20 & Moderately welded tuff; $20 \%$ crystals & -- & $\mathrm{T}$ & 100 & 200 & Pyroclastic and epiclastic rhyolite deposits \\
\hline Tscl & -- & 0 & 300 & Dacite and rhyolite lava flows and minor tuff; $25 \%$ crystals & Tql & -- & 0 & 500 & Flow-layered trachyandesite lava flows, domes, and plugs \\
\hline -- & нН & 20 & 150 & Densely to moderately welded andesite tuff; $50 \%$ crystals & -- & $\mathrm{CB}$ & 20 & 120 & Densely welded rhyolite tuff; $10 \%$ crystals \\
\hline Trt & -- & 0 & 100 & Rhyolite lava flows & Tds & -- & 0 & 250 & Porphyritic dacite lava flow dome \\
\hline Tlf & -- & 0 & 130 & $\begin{array}{l}\text { Locally aphyric trachyandesite to trachydacite flows; } 5-25 \% \\
\text { crystals }\end{array}$ & -- & IS & 0 & 800 & Densely welded trachydacite tuff; $15 \%$ crystals \\
\hline-- & $\mathrm{CB}$ & 0 & 30 & Densely welded rhyolite tuff; $20 \%$ crystals & Tha & -- & 0 & 250 & Locally vesicular andesite lava flows; $25 \%$ crystals \\
\hline-- & CS & 10 & 15 & Moderately to densely welded rhyolite tuff; $10 \%$ crystals & Tla & -- & 0 & 400 & Porphyritic andesite lava flows; also sandstone and tuff \\
\hline-- & IS & 0 & 400 & Moderately to densely welded trachydacite tuff; $12 \%$ crystals & -- & LF & 0 & 550 & Moderately to densely welded dacite tuff; $45-50 \%$ crystals \\
\hline-- & $\mathrm{RF}$ & 0 & 650 & Partly to densely welded rhyolite tuff; crystal poor & $\operatorname{Trr}$ & -- & 0 & 200 & Flow-layered rhyolite flows and flow domes; crystal poor \\
\hline-- & LF & 0 & 100 & Moderately to densely welded dacite tuff; $25-35 \%$ crystals & Tra & -- & 0 & 150 & Porphyritic andesite lava flows \\
\hline-- & RG & 50 & 1,400 & Moderately welded rhyolite tuff; $10 \%$ crystals & -- & $\mathrm{RM}$ & 50 & 500 & Moderately welded rhyolite tuff; $20 \%$ crystals \\
\hline-- & WW & 0 & 130 & Densely welded dacite tuff; $40 \%$ crystals & -- & WW & 0 & 2,000 & Densely welded dacite tuff; $40 \%$ crystals \\
\hline -- & $\mathrm{CW}$ & 12 & 160 & Densely to moderately welded dacite tuff; $40 \%$ crystals & -- & $\mathrm{CW}$ & 0 & 5 & Densely welded dacite tuff; crystal rich \\
\hline Tea & -- & 0 & 350 & Weakly porphyritic andesite lava flows & -- & ST & 0 & 200 & Moderately welded tuff; $20-30 \%$ crystals \\
\hline-- & ST & 0 & 150 & Tuff; crystal rich & & & & & \\
\hline \multicolumn{10}{|c|}{ Compilation of thickness of Tertiary rocks } \\
\hline \multicolumn{5}{|c|}{ Mountain range to the west: the southern part of the White Rock Mountains } & \multicolumn{5}{|c|}{ Mountain range to the east: the southern part of the Indian Peak Range } \\
\hline \multirow{2}{*}{\multicolumn{2}{|c|}{ Local units }} & $\begin{array}{c}\text { Minimum } \\
\text { thickness, } \mathrm{m}\end{array}$ & $\begin{array}{c}\text { Maximum } \\
\text { thickness, } m\end{array}$ & & \multicolumn{5}{|c|}{$\begin{array}{cc}\begin{array}{c}\text { Minimum } \\
\text { thickness, } m\end{array} & \begin{array}{c}\text { Maximum } \\
\text { thickness, } m\end{array}\end{array}$} \\
\hline & & 300 & 1,510 & & \multicolumn{2}{|c|}{ Local units } & 0 & 2,850 & \\
\hline \multicolumn{2}{|c|}{ Regional units } & 92 & 3,355 & & \multicolumn{2}{|c|}{ Regional units } & 170 & 4,375 & \\
\hline \multicolumn{2}{|l|}{ Total } & 392 & 4,865 & & Total & & 170 & 7,225 & \\
\hline \multicolumn{10}{|c|}{ Inferred thickness of volcanic rocks beneath valley axis, $100-3,500 \mathrm{~m}$} \\
\hline
\end{tabular}

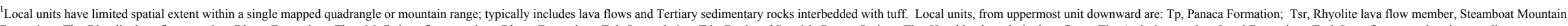

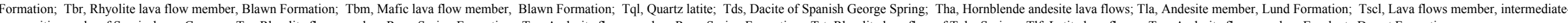
composition rocks of Serviceberry Canyon; Trr, Rhyolite flow member, Ryan Spring Formation; Tra, Andesite flow member, Ryan Spring Formation; Trt, Rhyolite lava flow of Tobe Spring; Tlf, Latite lava flows; Tea, Andesite flow member, Escalante Desert Formation.

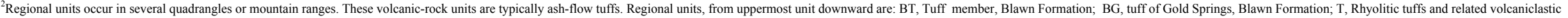

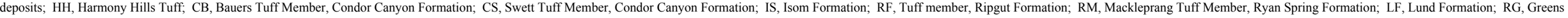
Canyon Tuff Member, Ryan Spring Formation; WW, Wah Wah Springs Formation; CW, Cottonwood Wash Tuff; ST, Sawtooth Peak Formation. 
Table 9. Compilation of volcanic-rock thickness from mountain ranges flanking northern part of Hamlin Valley

[Thickness data for the northern part of the White Rock Mountains from Best, Toth, and others (1989); thickness data for the east-central Mountain Home Range from Hintze (1986) and Hintze and Best (1987); leaders (--), unit not present]

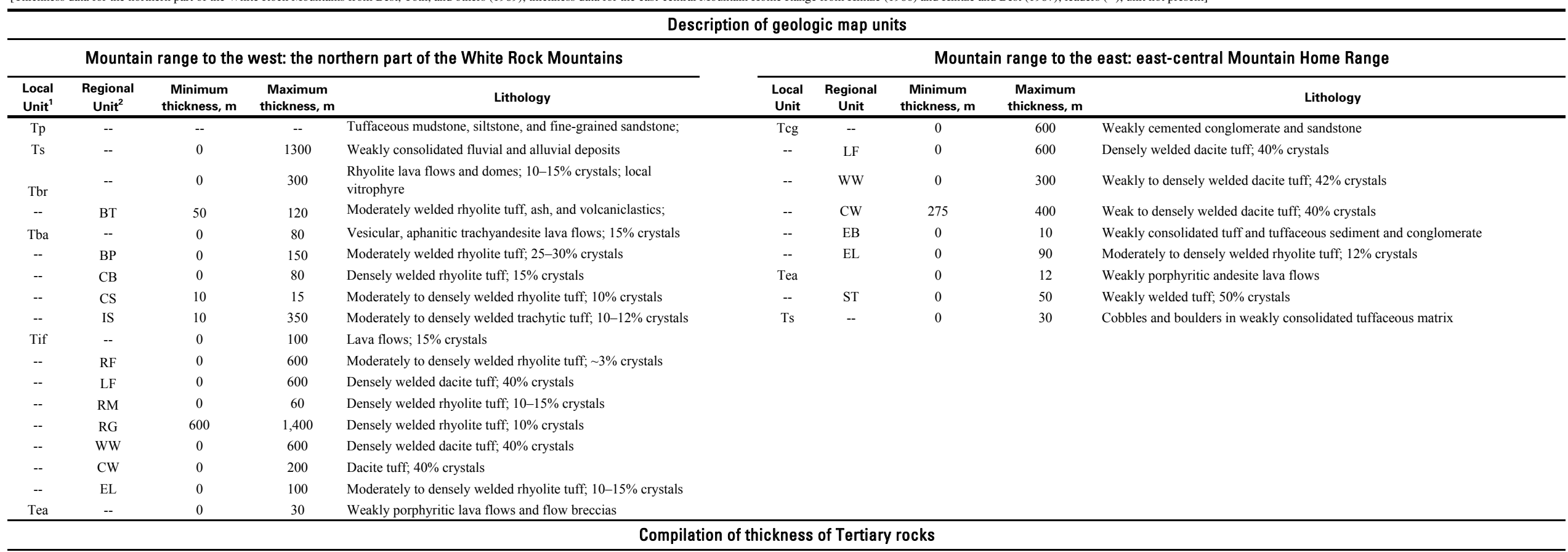

\begin{tabular}{|c|c|c|c|c|c|}
\hline \multicolumn{6}{|c|}{ Compilation of thickness of Tertiary rocks } \\
\hline \multicolumn{3}{|c|}{ Mountain range to the west: the northern part of the White Rock Mountains } & \multicolumn{3}{|c|}{ Mountain range to the east: east-central Mountain Home Range } \\
\hline & $\begin{array}{c}\text { Minimum } \\
\text { thickness, } m\end{array}$ & $\begin{array}{c}\text { Maximum } \\
\text { thickness, } m\end{array}$ & & $\begin{array}{c}\text { Minimum } \\
\text { thickness, } m\end{array}$ & $\begin{array}{c}\text { Maximum } \\
\text { thickness, } m\end{array}$ \\
\hline Local units & 0 & 1,810 & Local units & 0 & 642 \\
\hline Regional units & 670 & 4,275 & Regional units & 275 & 1,450 \\
\hline Total & 670 & 6,085 & Total & 275 & 2,092 \\
\hline \multicolumn{6}{|c|}{${ }^{3}$ Inferred thickness of volcanic rocks beneath valley axis, $3-3,000 \mathrm{~m}$} \\
\hline
\end{tabular}

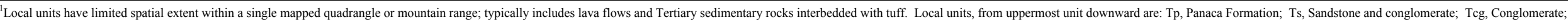
Tbr, Rhyolite member, Blawn Formation; Tba, Trachyandesite lava flow member, Blawn Formation; Tif, Lava flow member, Isom Formation; Tea, Andesite flow member, Escalante Desert Formation; Ts, Sedimentary rocks.

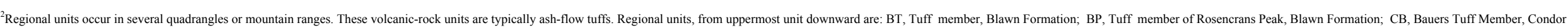

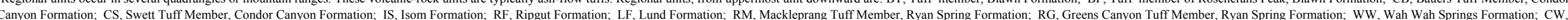
Cottonwood Wash Tuff; EB, Beers Spring Member, the Escalante Desert Formation; EL, Lamerdorf Tuff Member, Escalante Desert Formation; ST, Sawtooth Peak Formation.

${ }^{3}$ Thicknesses possibly overstated. Truly adjacent ranges (Limestone Hills, the southern part of the Snake Range, and the western part of the Mountain Home Range) seem to contain only minor amounts of Tertiary rocks. 
Table 10. Compilation of volcanic-rock thickness from mountain ranges flanking Snake Valley

[Thickness data for the Snake Range from Hose and others (1976), for the Confusion Range and Burbank Hills from Hose (1965) and Hintze (1974a); leaders (--), unit not present]

\begin{tabular}{|c|c|c|c|c|c|c|c|c|c|}
\hline \multicolumn{10}{|c|}{ Description of geologic map units } \\
\hline \multicolumn{5}{|c|}{ Mountain range to the west: Snake Range } & \multicolumn{5}{|c|}{ Mountain range to the east: Confusion Range and Burbank Hills } \\
\hline $\begin{array}{l}\text { Local } \\
\text { Unit }^{1}\end{array}$ & $\begin{array}{c}\text { Regional } \\
\text { Unit }^{2}\end{array}$ & $\begin{array}{c}\text { Minimum } \\
\text { thickness, } m\end{array}$ & $\begin{array}{c}\text { Maximum } \\
\text { thickness, } m\end{array}$ & Lithology & $\begin{array}{l}\text { Local } \\
\text { Unit }\end{array}$ & $\begin{array}{c}\text { Regional } \\
\text { Unit }\end{array}$ & $\begin{array}{c}\text { Minimum } \\
\text { thickness, } m\end{array}$ & $\begin{array}{c}\text { Maximum } \\
\text { thickness, } m\end{array}$ & Lithology \\
\hline
\end{tabular}

No Tertiary volcanic rocks present in northern, central, and southeastern parts of the Snake Range

Very minimal thickness of Tertiary volcanic rock in Confusion Range

Hintze (1974a) suggests 0-15 m of Cottonwood Wash Tuff and $15 \mathrm{~m}$ of Tunnel Spring Tuff

Compilation of thickness of Tertiary rocks

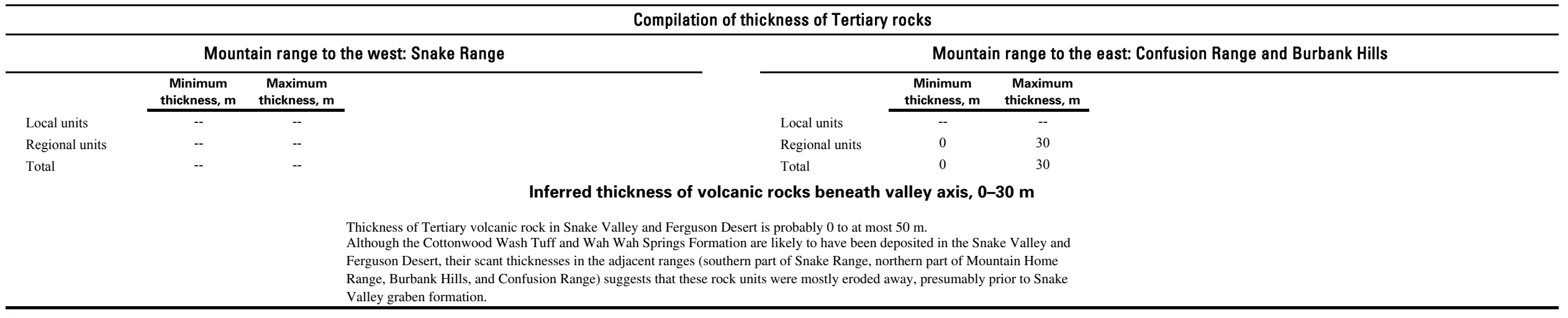

${ }^{1}$ Local units have limited spatial extent within a single mapped quadrangle or mountain range; typically includes lava flows and Tertiary sedimentary rocks interbedded with tuff.

${ }^{2}$ Regional units occur in several quadrangles or mountain ranges. These volcanic-rock units are typically ash-flow tuffs. 
Table 11. Compilation of volcanic-rock thickness from mountain ranges flanking southern part of Pine Valley

[Thickness data for Indian Peak Range from Best, Grant, and others (1987) and Best, Hintze, and Homes (1987); thickness data for the southern part of the Wah Wah Mountains from Best, Morris, and others (1987) and Abbott and others (1983); leaders (--), uni

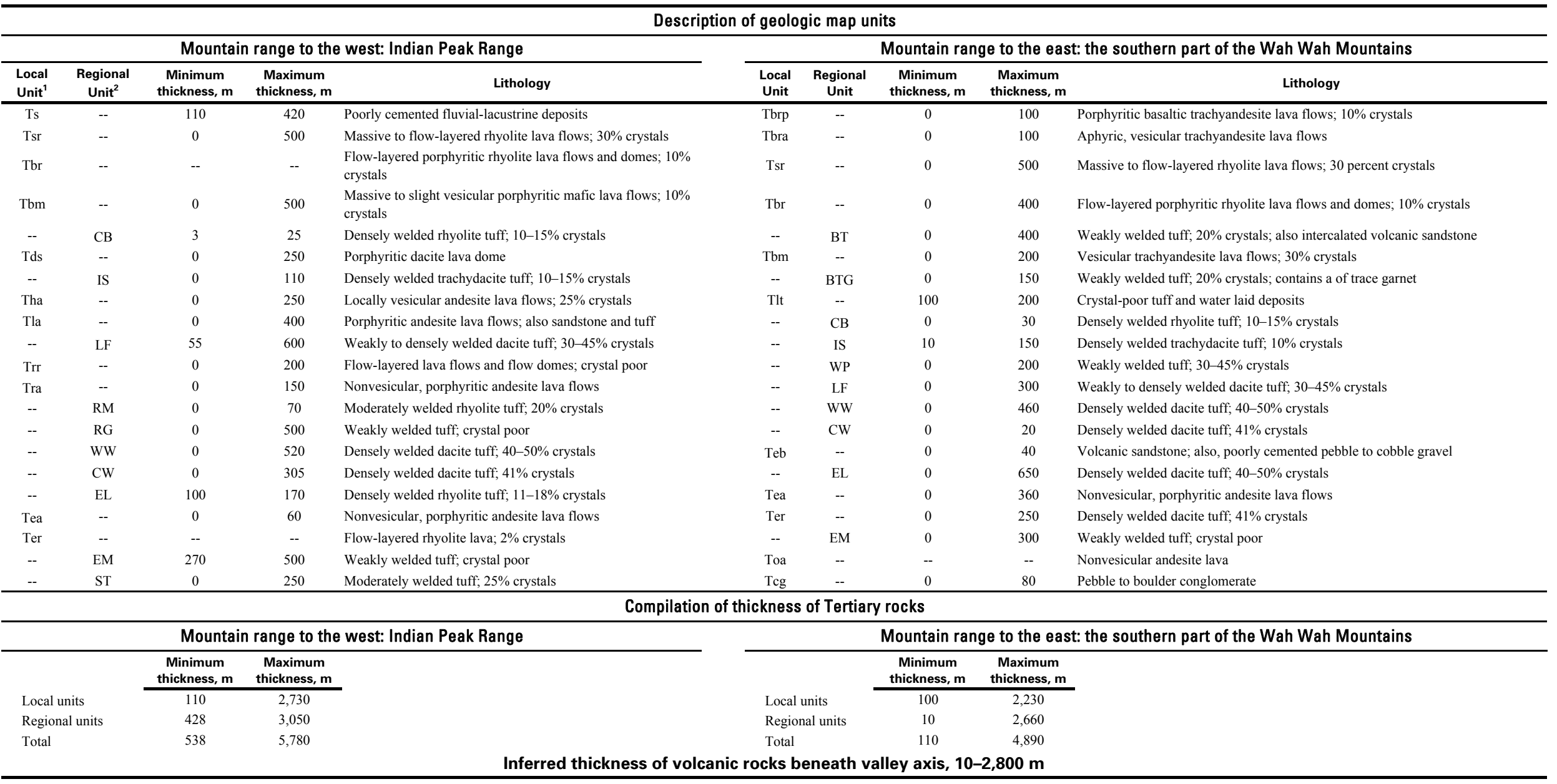

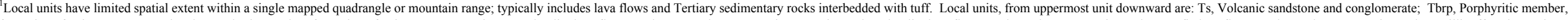

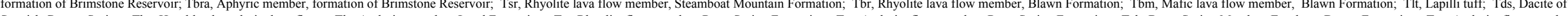

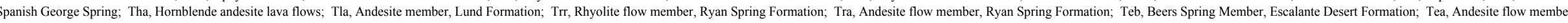
Escalante Desert Formation; Ter, Rhyolite flow member, Escalante Desert Formation; Toa, Andesitic lava flows; Tcg, Conglomerate.

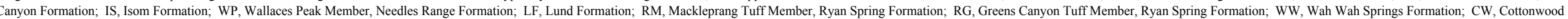
Wash Tuff; EL, Lamerdorf Tuff Member, Escalante Desert Formation; EM, Tuff of Marsden Spring, Escalante Desert Formation; ST, Sawtooth Peak Formation. 
Table 12. Compilation of volcanic-rock thickness from mountain ranges flanking northern part of Pine Valley

[Thickness data for central Mountain Home Range from Hintze (1981), Best and Hintze (1980), and Best, Hintze, and Homes (1987); thickness data for the northern part of the Wah Wah Mountains from Wheeler (1980) and Hintze (1974b); leaders (--), unit not pre

\begin{tabular}{|c|c|c|c|c|c|c|c|c|c|}
\hline \multicolumn{10}{|c|}{ Description of geologic map units } \\
\hline \multicolumn{5}{|c|}{ Mountain range to the west: central Mountain Home Range } & \multicolumn{5}{|c|}{ Mountain range to the east: the northern part of the Wah Wah Mountains } \\
\hline $\begin{array}{l}\text { Local } \\
\text { Unit }^{1}\end{array}$ & $\begin{array}{c}\text { Regional } \\
\text { Unit }^{2} \\
\end{array}$ & $\begin{array}{c}\text { Minimum } \\
\text { thickness, } m\end{array}$ & $\begin{array}{c}\text { Maximum } \\
\text { thickness, } m\end{array}$ & Lithology & $\begin{array}{c}\text { Local } \\
\text { Unit }\end{array}$ & $\begin{array}{c}\text { Regional } \\
\text { Unit }\end{array}$ & $\begin{array}{c}\text { Minimum } \\
\text { thickness, } m\end{array}$ & $\begin{array}{c}\text { Maximum } \\
\text { thickness, } m\end{array}$ & Lithology \\
\hline Ts & -- & 110 & 420 & Partly consolidated clayey, sandy, and conglomeratic deposits & $\mathrm{Tb}$ & -- & 0 & 500 & Volcanic (?) landslide-related breccia masses \\
\hline $\mathrm{Tc}$ & -- & 0 & 20 & Unconsolidated conglomerate and tuffaceous sandstone & $\mathrm{Tc}$ & -- & 0 & 50 & Conglomerate and tuffaceous sandstone \\
\hline -- & СВ & 0 & 6 & Densely welded rhyolite tuff; $20 \%$ crystals & Tba & -- & 0 & 150 & Mafic, aphanitic, vesicular lava flows; some phenocrysts \\
\hline -- & IS & 0 & 6 & Densely welded trachytic tuff; $10 \%$ crystals & -- & BT & 0 & 30 & Moderately welded rhyolite tuff, ash, and clastics; $10 \%$ crystals \\
\hline -- & WW & 0 & 370 & Moderately to densely welded dacite tuff; $42 \%$ crystals & -- & WP & 0 & 84 & Tuff \\
\hline -- & $\mathrm{CW}$ & 90 & 460 & Weak to densely welded dacite tuff; $42 \%$ crystals & -- & LF & 0 & 70 & Moderately welded dacite tuff; $42 \%$ crystals \\
\hline-- & EB & 24 & 55 & $\begin{array}{l}\text { Weakly consolidated tuff and tuffaceous sediment and } \\
\text { conglomerate }\end{array}$ & -- & WW & 0 & 116 & Moderately to densely welded dacite tuff; $45 \%$ crystals \\
\hline -- & $\mathrm{EL}$ & 0 & 43 & Moderately to densely welded rhyolite tuff; $12 \%$ crystals & -- & $\mathrm{CW}$ & 20 & 40 & Moderately welded dacite tuff; $37 \%$ crystals \\
\hline Tea & -- & 0 & 46 & Massive phenocryst-poor andesite lava & -- & TS & 0 & 61 & Rhyolite tuff \\
\hline -- & ST & 0 & 61 & Friable, porous, weakly welded tuff; $33-50 \%$ crystals & Тр & -- & 0 & 152 & Andesite lava and lava flow domes; also dacite tuff \\
\hline
\end{tabular}

Compilation of thickness of Tertiary rocks

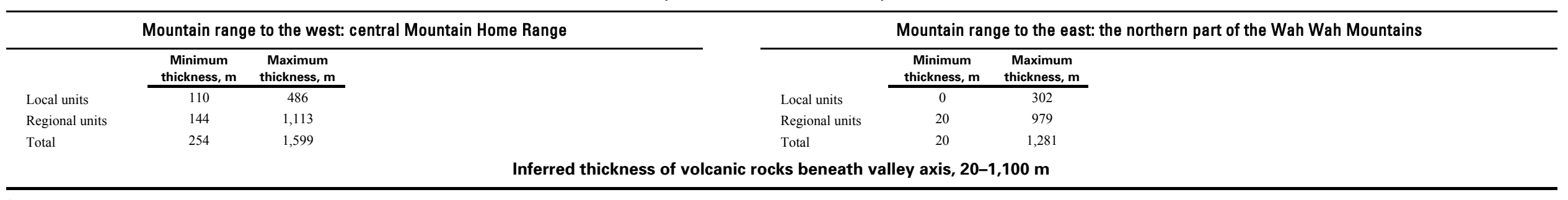

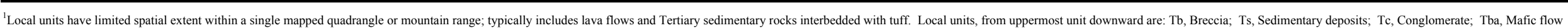
member, Blawn Formation; Tea, Andesite flow member, Escalante Desert Formation; Tp, Pre-Tunnel Spring volcanic rocks.

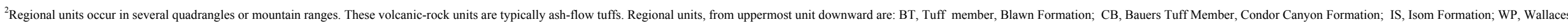

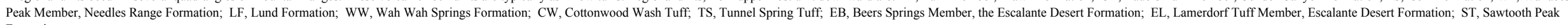
Formation. 
Table 13. Compilation of volcanic-rock thickness from mountain ranges flanking Wah Wah Valley

[Thickness data for the southern part of the Wah Wah Mountains from Abbott and others (1983) and Wheeler (1980); thickness data for the San Francisco Mountains from Best, Lemmon, and Morris (1989); leaders (--), unit not present]

\begin{tabular}{|c|c|c|c|c|c|c|c|c|c|}
\hline \multicolumn{10}{|c|}{ Description of geologic map units } \\
\hline \multicolumn{5}{|c|}{ Mountain range to the west: the southern part of the Wah Wah Mountains } & \multicolumn{5}{|c|}{ Mountain range to the east: San Francisco Mountains } \\
\hline $\begin{array}{l}\text { Local } \\
\text { Unit }\end{array}$ & $\begin{array}{c}\text { Regional } \\
\text { Unit }^{2}\end{array}$ & $\begin{array}{c}\text { Minimum } \\
\text { thickness, } m\end{array}$ & $\begin{array}{c}\text { Maximum } \\
\text { thickness, } m\end{array}$ & Lithology & $\begin{array}{c}\text { Local } \\
\text { Unit }\end{array}$ & $\begin{array}{c}\text { Regional } \\
\text { Unit }\end{array}$ & $\begin{array}{c}\text { Minimum } \\
\text { thickness, } m\end{array}$ & $\begin{array}{c}\text { Maximum } \\
\text { thickness, } m\end{array}$ & Lithology \\
\hline Tbrp & -- & 0 & 100 & Porphyritic basaltic trachyandesite lava flows; $10 \%$ crystals & Tdf & -- & 0 & 100 & Cobble to boulder volcanic debris flow deposits \\
\hline Tbra & -- & 0 & 100 & Aphyric, vesicular trachyandesite lava flows & Tsr & -- & -- & -- & Vesicular, porphyritic rhyolite lava flows and domes \\
\hline Tbr & -- & 0 & 400 & Flow-layered porphyritic rhyolite lava flows and domes; $10 \%$ crystals & Tsb & -- & 0 & 100 & Aphyric to porphyritic, vesicular basalt lava flows \\
\hline-- & BT & 0 & 400 & $\begin{array}{l}\text { Weakly welded tuff; } 20 \% \text { crystals; also intercalated volcanic } \\
\text { sandstone }\end{array}$ & Tbr & -- & -- & -- & Flow-layered porphyritic rhyolite lava flows and domes; $20-30 \%$ crystals \\
\hline \multirow[t]{2}{*}{ Tbm } & -- & 0 & 200 & Vesicular trachyandesite lava flows; $30 \%$ crystals & -- & BT & 0 & 650 & Weakly welded tuff; $20 \%$ crystals; also intercalated volcanic sandstone \\
\hline & BTG & 0 & 150 & Weakly welded tuff; $20 \%$ crystals; contains a of trace garnet & Tbm & -- & 0 & 200 & Vesicular trachyandesite lava flows; $25 \%$ crystals \\
\hline Tlt & -- & -- & -- & Crystal-poor tuff and water laid deposits & Tsp & -- & 0 & 1,000 & Flow-layered trachydacite lava flows: $33 \%$ crystals \\
\hline -- & СВ & 0 & 30 & Densely welded rhyolite tuff; $10-15 \%$ crystals & -- & $\mathrm{CB}$ & 0 & 18 & Densely welded rhyolite tuff; $10 \%$ crystals \\
\hline-- & Is & 0 & 28 & Densely welded trachydacite tuff; $10 \%$ crystals & -- & Is & 0 & 5 & Densely welded trachydacite tuff; $10 \%$ crystals \\
\hline-- & WP & 0 & 200 & Weakly welded tuff; $30-45 \%$ crystals & -- & TCT & 0 & 200 & Densely to moderately welded tuff; $40 \%$ crystals \\
\hline-- & LF & 350 & 500 & Weakly to densely welded dacite tuff; $30-45 \%$ crystals & -- & $\mathrm{LF}$ & 0 & 300 & Densely welded dacite tuff; $40 \%$ crystals \\
\hline-- & WW & 0 & 460 & Densely welded dacite tuff; $30-45 \%$ crystals & -- & ww & 0 & 250 & Densely welded dacite tuff; $40 \%$ crystals \\
\hline-- & $\mathrm{CW}$ & 0 & 20 & Densely welded dacite tuff; $30-45 \%$ crystals & -- & $\mathrm{CW}$ & 0 & 10 & Densely welded dacite tuff; $30-45 \%$ crystals \\
\hline \multirow[t]{2}{*}{ Teb } & -- & 0 & 40 & Volcanic sandstone; also, poorly cemented pebble to cobble gravel & -- & EL & 0 & 200 & Moderately welded tuff; $15 \%$ crystals \\
\hline & EL & 0 & 650 & Densely welded rhyolite tuff; $10-15 \%$ crystals & Ths & -- & 0 & 700 & Porphyritic andesite to dacite lava flows; $10 \%$ crystals \\
\hline \multirow[t]{2}{*}{ Tela } & -- & -- & -- & Nonvesicular, aphanitic to crystal poor andesite lava flows & Tsh & -- & 0 & 600 & Nonvesicular, andesite lava flows; $20 \%$ crystals \\
\hline & EM & 0 & 70 & Weakly welded tuff; crystal poor & Thr & -- & 0 & 10 & Pebble, cobble, and boulder conglomerate; siltstone to shale matrix \\
\hline Toa & -- & -- & -- & Nonvesicular andesite lava & & & & & \\
\hline Tcg & -- & 0 & 80 & Pebble to boulder conglomerate & & & & & \\
\hline
\end{tabular}

Compilation of thickness of Tertiary rocks

\begin{tabular}{|c|c|c|c|c|c|}
\hline \multicolumn{3}{|c|}{ Mountain range to the west: the southern part of the Wah Wah Mountains } & \multicolumn{3}{|r|}{ Mountain range to the east: San Francisco Mountains } \\
\hline & $\begin{array}{c}\text { Minimum } \\
\text { thickness, } m\end{array}$ & $\begin{array}{c}\text { Maximum } \\
\text { thickness, } m\end{array}$ & & $\begin{array}{c}\text { Minimum } \\
\text { thickness, } m\end{array}$ & $\begin{array}{c}\text { Maximum } \\
\text { thickness, } m\end{array}$ \\
\hline Local units & 0 & 920 & Local units & 0 & 2,710 \\
\hline Total & 350 & 3,248 & Total & 0 & 4,343 \\
\hline
\end{tabular}

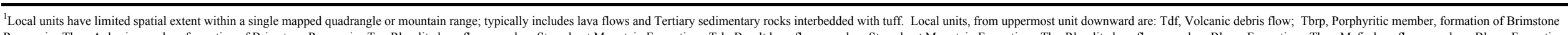

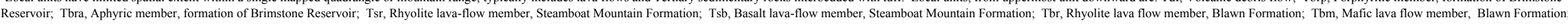

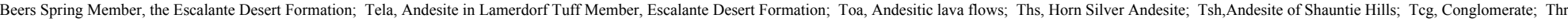
Conglomerate of High Rock Pass are.

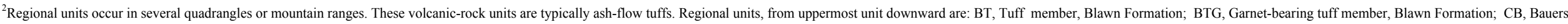

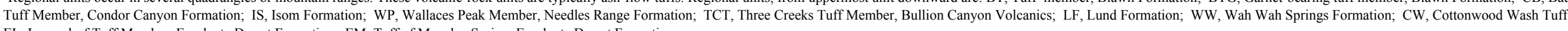
EL, Lamerdorf Tuff Member, Escalante Desert Formation; EM, Tuff of Marsden Spring, Escalante Desert Formation. 